\title{
WestVirginiaUniversity
}

THE RESEARCH REPOSITORY @ WVU

Graduate Theses, Dissertations, and Problem Reports

2017

\section{Two Essays on Macro-Financial Linkages}

Jennifer Moreale

Follow this and additional works at: https://researchrepository.wvu.edu/etd

\section{Recommended Citation}

Moreale, Jennifer, "Two Essays on Macro-Financial Linkages" (2017). Graduate Theses, Dissertations, and Problem Reports. 6257.

https://researchrepository.wvu.edu/etd/6257

This Dissertation is protected by copyright and/or related rights. It has been brought to you by the The Research Repository @ WVU with permission from the rights-holder(s). You are free to use this Dissertation in any way that is permitted by the copyright and related rights legislation that applies to your use. For other uses you must obtain permission from the rights-holder(s) directly, unless additional rights are indicated by a Creative Commons license in the record and/ or on the work itself. This Dissertation has been accepted for inclusion in WVU Graduate Theses, Dissertations, and Problem Reports collection by an authorized administrator of The Research Repository @ WVU.

For more information, please contact researchrepository@mail.wvu.edu. 


\title{
Two Essays on Macro-Financial Linkages
}

\author{
Jennifer Moreale
}

Dissertation submitted to the

College of Business and Economics

at West Virginia University

in partial fulfillment of the requirements for the degree of

Doctor of Philosophy in Business Administration, Concentration in Finance

\author{
Alexander Kurov, Ph.D., Chair \\ Costanza Meneghetti, Ph.D. \\ Ann Marie Hibbert, Ph.D. \\ Gulnara Zaynutdinova, Ph.D. \\ Arabinda Basistha, Ph.D.
}

Department of Finance

Morgantown, West Virginia

2017

Keywords: macro-financial linkages, credit cycle, opacity, portfolio excess returns, yield curve, quantitative easing, Treasury futures, Eurodollar futures, price discovery, information shares, macroeconomic news.

Copyright 2017 Jennifer Moreale 


\title{
ABSTRACT \\ Two Essays on Macro-Financial Linkages
}

\author{
Jennifer Moreale
}

In the following essays I examine the effects of two unique macro-financial conditions - tight credit and unconventional monetary policy - in an investment and a price discovery setting. I address two major questions from the macro-finance literature: (1) what are the states of nature in which excess returns are mostly affected? And, (2) does unconventional monetary policy influence the term structure of interest rates?

Results from my first essay show a differential effect of the credit cycle on firms in the crosssection. Firm's excess returns are particularly affected in periods of tight credit conditions and the effect of the credit cycle is heterogeneous across firm types. Overall I concluded that tight credit conditions have a more severe impact on opaque firms and that opacity includes both smallness and access to credit sensitivity measures.

In my second essay I find quantitative easing and days of macroeconomic announcements are not a significant driver of price discovery when examining the impact of unconventional monetary policy along the yield curve. I argue that the unexpected result is due to the presence of a time-varying risk premium component which significantly influenced the yield curve during the period of quantitative easing examined. 


\section{TABLE OF CONTENTS}

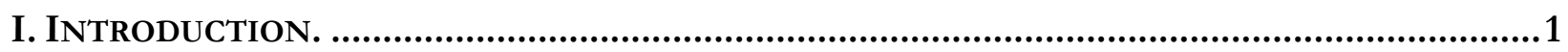

II. Chapter 1. Returns of Opaque Firms across the Credit Cycle .............................2

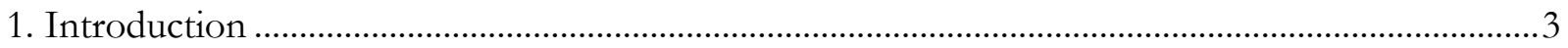

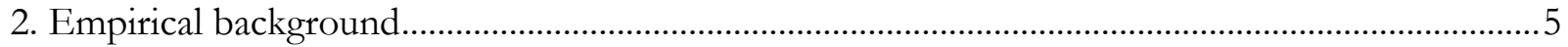

2.1 Literature on firm characteristics and stock returns ................................................................... 5

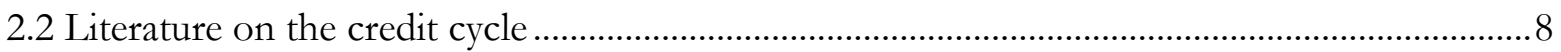

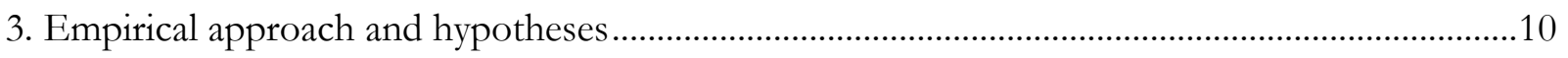

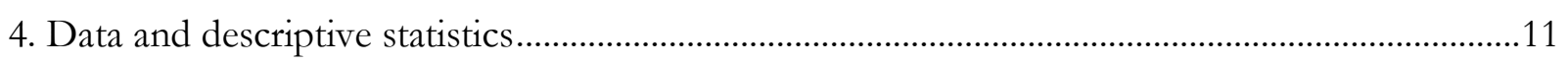



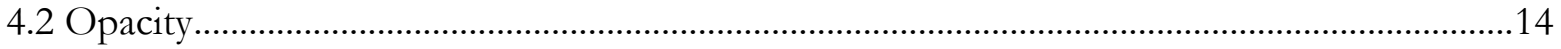

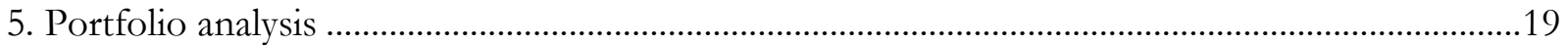

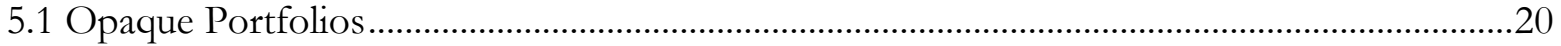

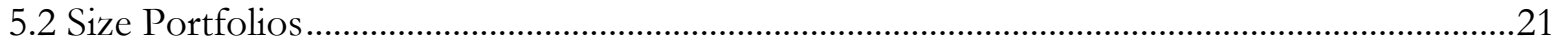

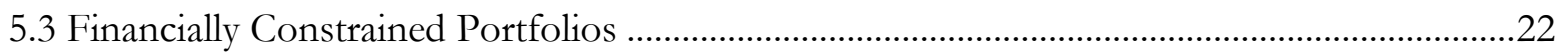

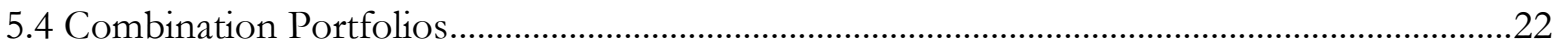

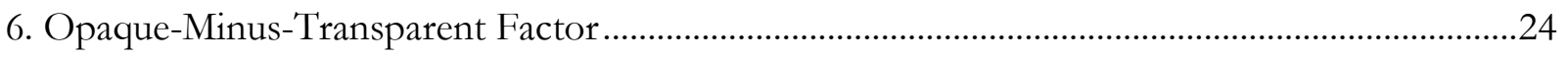

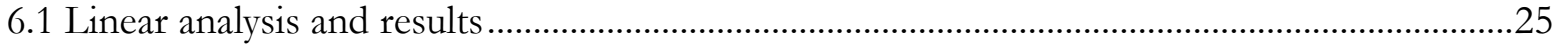

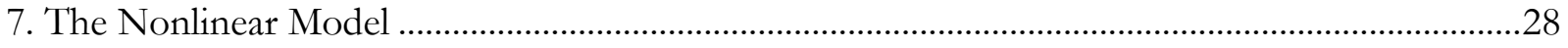

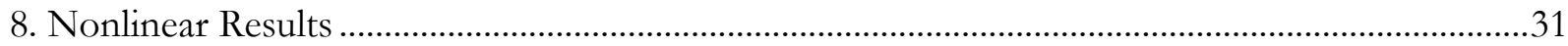

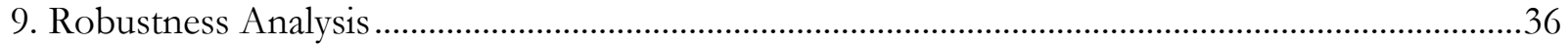

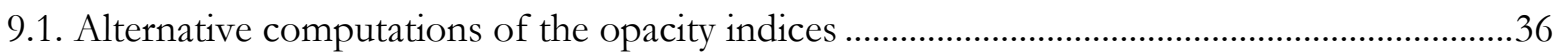

9.2. An alternative sorting procedure for portfolios............................................................................. 37

9.3. An alternative regime switching model specification.................................................................38

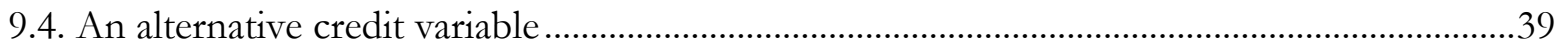

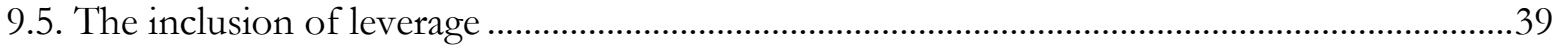

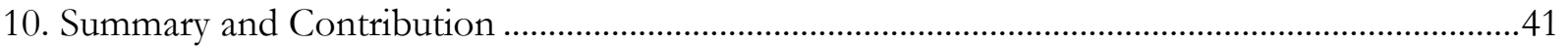

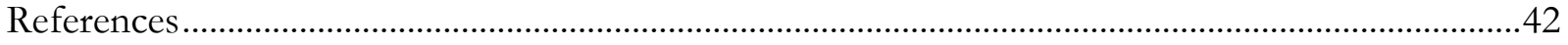

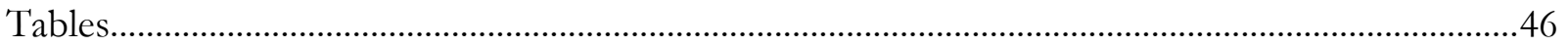

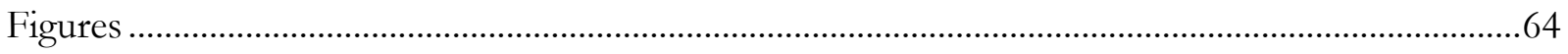




\section{Capter 2. Price Discovery along the Yield Curve: Does UnConventional}

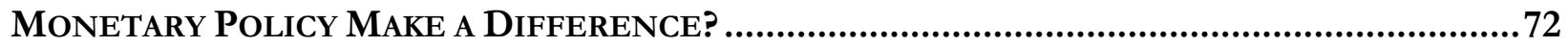

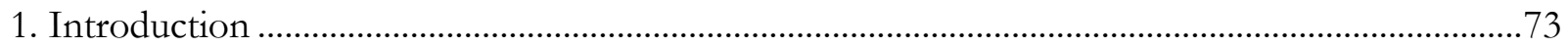

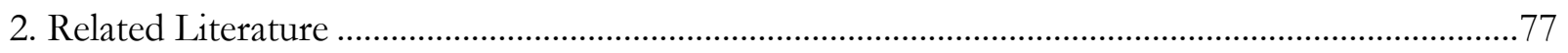

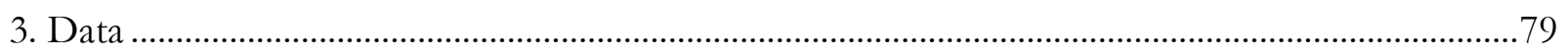

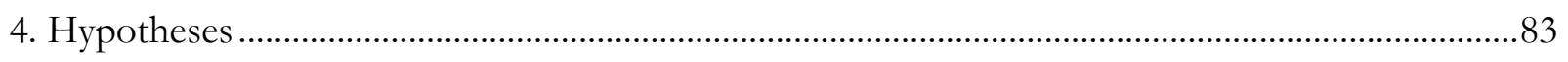

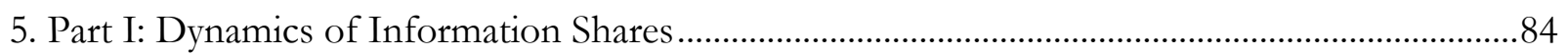

5.1 Information shares adopting Hasbrouck (1995) price discovery model...................................85

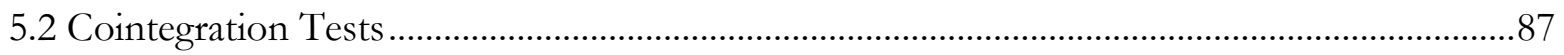



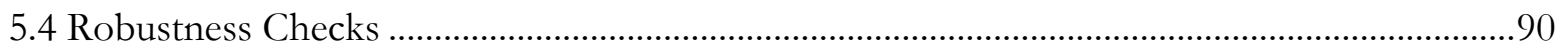

6. Part II: Macroeconomic News and Dynamics of Information Shares ..........................................91

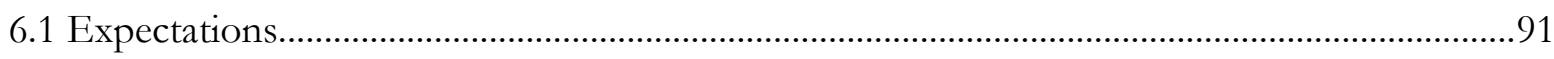

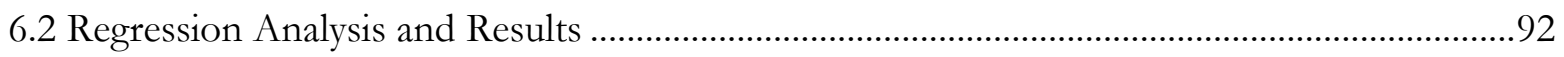

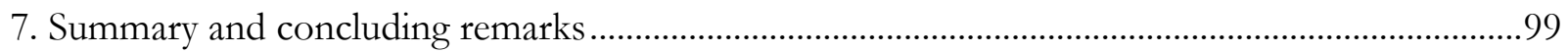

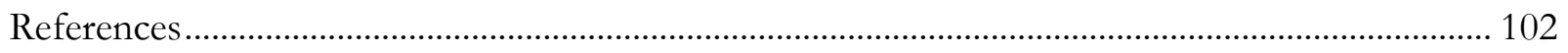

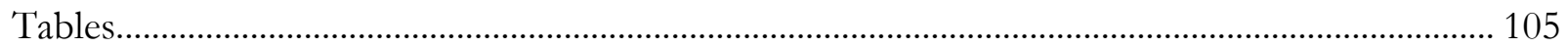

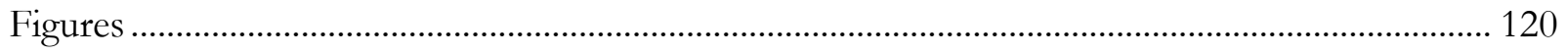




\section{INTRODUCTION.}

In the following essays I examine the effects of two unique macro-financial conditions - tight credit and unconventional monetary policy - in an investment and a price discovery setting. My goal is to address two major questions from the macro-finance literature: (1) what are the states of nature in which excess returns are mostly affected? And, (2) does unconventional monetary policy influence the term structure of interest rates?

In the first essay I investigate the role of the credit cycle in explaining observed risk premia within a regime switching framework. Specifically, I study the impact of credit cycles on excess returns to investigate potential increased sensitivities across credit regimes for portfolios of opaque firms. I expect the relationship between credit and excess returns across opaque firms to be best represented by a nonlinear model capturing the different effects of the credit cycle. Results show that i) tight credit conditions have a more severe impact on opaque firms and that ii) opacity includes both smallness and access to credit sensitivity measures. I contribute to the macro-finance literature by finding a differential effect of the credit cycle on firms in the cross-section.

In the second essay I examine the impact of unconventional monetary policy on price discovery along the yield curve. The question addressed has important implications for the understanding of monetary policy effects on price discovery through the investor's expectations channel. My study consists of two parts. First, I adopt Hasbrouck's (1995) information share methodology to examine the cross-sectional and time-series price informational contribution of Treasury and Eurodollar futures contracts. This allows me to capture the change in relative information shares across the recent financial crisis. Second, I investigate the role of days with general and specific macroeconomic news announcements as drivers of relative information shares across maturities and quantitative easing periods. Contrary to my expectations, quantitative easing is not a significant driver of price discovery along the yield curve, and days of general macroeconomic news announcements do not seem to significantly matter. Given the unexpected results, I advance an alternative explanation related to the macro-finance term structure literature: futures prices contained a time-varying risk premium component which significantly influenced the yield curve beyond the impact of investor's expectations. 


\title{
II. Chapter 1. Returns of Opaque Firms across the Credit CyCle ${ }^{1}$
}

\begin{abstract}
We examine the role of credit risk in explaining observed risk premia within a regime switching framework. Credit risk appears particularly important in opaque firms, suggesting these firms may have difficulty obtaining funds in poor states of nature, when they most need assistance. Through a multivariate regime-switching model, we examine the nonlinearity of stock returns across the credit cycle and find a differential effect of credit across firms of different opacity levels. Furthermore, we examine the time series behavior of the opacity index and its premium by computing a new factor, the Opaque-Minus-Transparent (OMT) factor. We conclude that the degree of opacity includes both smallness and access to credit sensitivity measures and it is an influential firm characteristic explaining the heterogeneous sensitivity of excess returns across the credit cycle.
\end{abstract}

${ }^{1}$ This essay is based on a paper coauthored with Harry J. Turtle. 


\section{Introduction}

We study the impact of credit cycles on excess returns to investigate heterogeneous effects across credit regimes on portfolios of opaque firms. Our contention is that opaque firms may be especially prone to asymmetric information problems that limit access to external sources of funds through the credit cycle. We hypothesize that the returns of opaque firms will be especially hampered in periods of low credit, and we empirically capture credit regimes within a multivariate Markov regime-switching model across opaque portfolios. A Markov regime switching model captures changes in the investment environment, the volatility dynamics, and the nonlinear relationship between the credit cycle, the firm's opacity level and an investor's required excess returns.

By opacity in our study we refer to the characteristic that influences access to funds and investor behavior. To give a concrete example, imagine a car manufacturing firm with glass walls and a pharmaceutical firm with concrete walls and no windows. Looking at the car firm, an investor can clearly see the output produced inside the firm and its manufacturing process. The valuation of the car firm becomes a straightforward task given the tangibility of the output and the knowledge of the production process and property, plant, and equipment. However, when the investor looks at the pharmaceutical firm he is unable to clearly understand the output and profitability of the firm's projects. Valuing the pharmaceutical firm is a challenging task. We say that the pharmaceutical firm is highly opaque due to complexity in tangibility and valuation difficulties due to embedded real options.

The concept of opacity can be applied to financial markets: the uncertainty concerning the valuation of opaque firms worsens in poor economic conditions leading investors to demand an opacity premium. Required premia should be highly dependent on the overall level of credit in the economy especially because opaque firms have limited access to external capital and recessions lead 
to tighter credit conditions (Hatzius, Hooper, Mishkin, Schoenholtz and Watson, 2010; Davig and Hakkio, 2010; Boissay, Collard and Smets, 2013; Hubrich and Tetlow, 2014; Morley, 2015).

Although opaque firms know their true value, they may have difficulty in conveying this information to investors or lenders. We investigate how this opacity premium varies according to credit conditions and we hypothesize that the credit cycle has heterogeneous effects on the returns of opaque firms. This concept is further supported by Hubrich and Tetlow (2014):

"The importance of financial factors tends to be episodic in nature. In normal times, $[\ldots]$ the financing decision is in some sense subordinate to the real-side decisions of the firm; credit doesn't matter. In other times, when the financial system is not operating normally, financial frictions become important as lending terms and standards tighten, making the interest rate a much less reliable metric of the cost of funds, broadly defined. During such times, which we will call stress events, credit can seem like it is the only thing that matters."

The credit cycle influences a firm's financial decisions and stock returns and its dynamic effect should be especially noticeable across firms with different levels of asymmetric information, access to credit, and financial stability. In our study, these firm characteristics are captured by our opacity index.

We argue that differences in firm opacity is a key factor that causes differences in required excess returns and in the sensitivity of firm value across credit conditions. We advance two related hypotheses: (a) opaque firms should be most sensitive to credit conditions and (b) opacity should subsume both smallness and access to credit sensitivity. We expect the relationship between credit and excess returns across opaque firms to be best represented by a nonlinear multivariate Markov regime-switching model capturing the different effects of the credit cycle.

What is novel about our study is the connection between opacity, credit states, and required excess returns. Results clarify the factors behind the different sensitivity across opacity levels and are hoped to shed light on the effect of the credit cycle on investor portfolios and financial markets. By understanding the state of nature in which excess returns are high, we contribute to the macro- 
finance literature linking the equity premium to underlying economic conditions and to how monetary conditions are expected to differentially impact firms in the cross-section. Lastly, our results support the credit view where credit has a constructive role in determining monetary policy actions.

In summary, we find opaque firm returns and the credit cycle are related. Opaque firms are affected the most across the credit cycle and opacity subsumes both a size and financial constraint effect. The remainder of the paper is organized as follows. Section 2 provides information on related literature and results. Section 3 outlines our empirical approach and hypotheses. Section 4 describes the data along with the computation of the opacity index and the identification of the credit cycle. Sections 5 analyzes portfolio returns across various firm characteristics. Section 6 introduces the Opaque-Minus-Transparent (OMT) factor and reports results from a linear analysis. The nonlinear model is described in Section 7 and the results are reported in Section 8. Robustness checks and summary of findings conclude the paper in Sections 9 and 10, respectively.

\section{Empirical background}

\subsection{Literature on firm characteristics and stock returns}

Our study builds upon the work of Perez-Quiros and Timmermann (2000) who empirically investigate the asymmetry of returns across business cycle and firm size through a regime-switching model. During a recession with lower access to credit, small firms are affected more than large firms due to tighter and worsening credit conditions. This causes the stock returns of small firms to be more sensitive than those of large firms. Small firms are found to have higher unusual returns in periods of low credit in order to compensate for the higher risk incurred, as Fama and French (1989) initially argued. 
Lamont, Polk and Saa-Requejo (2001) investigate a similar question but shift their hypothesis to the effect of firm financial constraints on stock returns. They suggest that financial constraints cause return asymmetries; they test this hypothesis by controlling for the size-effect and find that, unlike small firms, financially constrained firms earn lower returns than unconstrained firms and are not particularly exposed to credit conditions.

The Lamont, Polk and Saa-Requejo (2001) results differ from Perez-Quiros and Timmermann (2000) and question the hypothesized risk and size effect underlying asset pricing and nonlinear returns. Perez-Quiros and Timmermann posit that during a recession - characterized by low credit small firms are more sensitive to economic conditions and have greater returns than large firms. Bad credit conditions have a positive effect on small firm stock returns relative to large firms because of compensation for a higher risk. Small firms are typically financially constrained, young, uncollateralized, bank dependent firms (Gertler and Hubbard, 1988; Kashyap, Stein, and Wilcox, 1993; Gertler and Gilchrist, 1994). Contrary to Perez-Quiros and Timmermann's redults, Lamont, Polk and Saa-Requejo suggest that financially constrained firms - typically small firms - experience lower returns than financially sound firms - typically large firms. A low access to credit has a negative effect on small firm stock returns relative to large firms.

Perez-Quiros and Timmermann (2000) focus on two concepts: i) small firms are on average more financially constrained than large firms, and ii) changing credit market conditions have heterogeneous effects across firm types (as observed in Kyiotaki and Moore, 1997; Bernanke and Gertler, 1989; Gertler and Gilchrist, 1994). In contrast, Lamont, Polk and Saa-Requejo (2001) rely on the idea that size and financial constraints are not perfectly correlated (Fazzari, Hubbard and Petersen, 1988; Gertler and Hubbard, 1988; Kashyap, Lamont and Stein, 1994). Whited and Wu (2006) and Livdan, Sapriza and Zhang (2009) revisit this return premium issue in relation to financial constraints and find that (1) more financially constrained firms have an annual return premium of 
approximately $2.5 \%$ compared to less financially constrained firms (Whited and Wu); (2) the financial constraint effect dominates the size effect; (3) there is a relationship between financial constraint risk and the business cycle: cumulative stock returns of constrained firms either coincide or lead recessions and decline during expansions. Whited and Wu further argue that their analysis is more accurate than Lamont, Polk and Saa-Requejo (2001) because their financial constraints index is able to isolate firm characteristics.

The Perez-Quiros and Timmermann (2000) and Lamont, Polk and Saa-Requejo (2001) findings are important because they contribute to issues in both finance and macroeconomics. From a macroeconomics perspective, Perez-Quiros and Timmermann suggest that monetary policy has a role through the credit channel. In contrast, Lamont, Polk and Saa-Requejo suggest that monetary policy, credit conditions and business cycles have nothing to do with the observed return premium. From a financial perspective, Perez-Quiros and Timmermann suggest a size and risk effect explanation for the asymmetry of returns, while Lamont, Polk and Saa-Requejo highlight the financial constraint effect. The two studies also differ in policy implications. Perez-Quiros and Timmermann find that small firms are more sensitive to monetary policy and credit conditions, while Lamont, Polk and Saa-Requejo suggests expansive monetary policy is ineffective in increasing the investment level in financially constrained firms.

Although Perez-Quiros and Timmermann (2000) and Lamont, Polk and Saa-Requejo (2001) reach contrasting results, the two studies have an underlying common focus on the opacity variable addressed in our paper. Opaque firms are small (cf., Perez-Quiros and Timmermann), young firms with low earnings, small equity base, low dividends, intangible assets (Berger and Turtle, 2012) and limited access to external financing (cf., Lamont, Polk and Saa-Requejo).

Perez-Quiros and Timmermann (2000) and Lamont, Polk and Saa-Requejo (2001) also acknowledge that credit conditions, access to credit, inability to borrow and dependence on bank 
loans are related to firm performance and the characteristics examined. However, Perez-Quiros and Timmermann and Lamont, Polk and Saa-Requejo account for recessions by using proxies that capture stringent credit conditions, credit constraints, and inability to borrow. On the other hand, we directly incorporate credit and the opacity factor in our research.

We account for both opacity and credit by directly adding the credit cycle in our analysis and focusing on portfolio returns for opaque firms across credit regimes in a multivariate setting. We posit that credit and opacity are missing elements in previous work and, when considered together, should explain the observed risk premia and nonlinearity of stock returns.

\subsection{Literature on the credit cycle}

There is a need to incorporate the credit level in macrofinancial research to examine the impact of policy on financial markets. Given credit spillovers on the real economy and its strong relationship with the financial sector, it is essential to further investigate and understand the direct effects of the credit cycle on portfolios, its impact on required excess returns, and the effectiveness of monetary policy channels. Credit from the banking sector facilitates investment, consumption and steady economic growth. In contrast, credit shocks have adverse effects on the real sector: excessive levels of credit have been identified as a primary source and a reliable predictor for the financial crisis (Gourinchas and Obstfeld, 2011); while restrictive levels of credit cause underinvestment and slow growth (Buncic and Melecky, 2013).

Borio, Fulfine and Lowe (2001) find that recessions and expansions are characterized by different levels of credit: booms are associated with rapid credit growth, artificially low lending spreads, and large increases in equity prices; busts are characterized by credit contractions, increased spreads, and equity price declines. Gorton and He (2005) investigate the effect of bank competition on credit cycles in an asset pricing context. The authors find that different levels of credit affect firm performance and that stock returns behave differently across economic states. Fama and French 
(1989) find evidence supporting a larger risk premium: when economic conditions are unfavorable, firms offer a higher return to encourage substitution between consumption and investment. Rey (2013) identifies excessive credit growth with a global financial cycle, as credit across economies is extremely volatile, procyclical, and negatively related to financial stress indicators.

These are concepts of a growing literature drawing from Mishkin (1978), Bernanke (1983) and Gertler (1988) who were among the initial authors to recognize the importance of bank credit for financial markets. They gave rise to the so-called credit view - the notion that credit mattered more than the level of bank money and it constituted an enhancement mechanism in the economy (Bernanke and Gertler, 1995). Monetary policy influences firm investments through both the availability of credit and its impact on stock returns (Kashyap, Setin, and Wilcox, 1993; Thorbecke, 1997).

In a more recent study, Adrian and Shin (2008) stress that non-monetary sources of finances have become increasingly important and that financial markets have substantial impact on both credit creation and financial stability. Similarly, Schularick and Taylor (2009) investigate the role of credit as an influencing factor through an in-depth historical account of money and credit fluctuations. The authors find that the financial system generates economic instability through endogenous credit bubbles. Financial markets can in fact amplify economic shocks such as credit crunches through changes in the external finance premium (Morley, 2015). It is our hypothesis that this premium is especially severe for opaque firms which are more sensitive to a financial accelerator effect: higher borrowing costs arise due to an overall deterioration of financial conditions in a period of low credit (Davig and Hakkio, 2010). Our expectations are in line with Bougheas, Mizen, and Yalcin (2006) who find that the interaction of firm-specific characteristics with monetary policy lead to different market responses; small, risky and young firms are affected the most by monetary tightening when compared to the impact on larger, secure firms. 
Credit influences investor sentiment. Berger and Turtle (2012) in fact suggest that investor sentiment has a stronger impact on opaque firms. Therefore, during periods of low credit, investors form dampened expectations about the future that then influence market prices. We hypothesize that firms most sensitive to investor sentiment will be most affected by the credit cycle and we expect opaque firms to be most constrained by the availability of funds especially in periods of low credit. Judge and Korzhenitskaya (2012) further motivates our research question. They find that the supply of credit is found to be inelastic and that specific type of firms face different prices and limited debt availability from lenders due to their characteristics.

\section{Empirical approach and hypotheses}

We adopt an approach that combines both an analysis across portfolio characteristics and a nonlinear model. We first run a set of linear models in order to capture the basic relationship between opacity and returns, and between credit, opacity and returns. The linear approach is supplemented by the construction of our Opaque-Minus-Transparent (OMT) factor which captures the time-series opacity premia.

We further develop our nonlinear model and build upon the work of Perez-Quiros and Timmermann (2000) with a two state multivariate Markov regime-switching model. Our main analysis is based on three, five, or ten quantile portfolios that range from low to high levels of opacity. Portfolios are also constructed as a combination of either opacity and size or opacity and financial constraint level in order to examine the excess returns after controlling for additional characteristics.

External funding and stock returns behave differently across the credit cycle and, in periods of low credit, lenders avoid riskier, opaque firms. Due to this dynamic impact, a nonlinear regimeswitching model is more appropriate to test our hypotheses and describe the relationship between 
excess returns and credit levels while capturing the different credit regimes and their heterogeneous effect across opacity levels. Controlling for firm characteristics and credit-sensitive variables, we predict nonlinear returns across the credit cycle and firm opacity levels. These predictions lead us to the following hypotheses:

Hypothesis 1 (H1): Returns to opaque firms are more sensitive to changes in credit conditions.

Hypothesis 2 (H2): Opacity subsumes both smallness and access to credit sensitivity measures.

Our first hypothesis is motivated by previous literature implying that opacity is a credit-sensitive portfolio characteristic affecting the relationship between returns and credit conditions. Opaque firms, mostly small and private firms, are able to finance their operations from external sources less easily than transparent firms and are more sensitive to investor sentiment (Berger and Turtle, 2012). The characteristics underlying opaque firms motivate our second hypothesis: opacity entails specific firm characteristics in connection to both a size and a financial constraint premium. We therefore expect the opacity premium to include both size and credit sensitivity premia.

\section{Data and descriptive statistics}

Credit is the residual component from running the natural logarithm of total bank credit of all commercial banks on a time trend. Total commercial banks credit is retrieved by the Federal Reserve Bank of St. Louis. Our approach captures periods of low and high credit in the economy. Our proxy for opacity is constructed from measures of firm size, age, financial constraints, research and development $(\mathrm{R} \& \mathrm{D})$, book-to-market, asset tangibility and earnings management. In general, we expect opacity to increase with the following firm characteristics: smallness, youth, financial constraints, R\&D, low tangibility, and earnings management (Baker and Wurgler, 2006; Sato, 2013; Berger and Turtle, 2012). 
Monthly stock returns from 1973 to 2015 are from the Center for Research in Security Prices (CRSP) database. Firm level financial data is retrieved from COMPUSTAT. Variables are winsorized at the $1 \%$ and $99 \%$ level, and the sample contains only firm-year combinations with non-missing data used to compute the indices. ${ }^{2}$ Following Fama and French (1992), monthly returns from July t to June $\mathrm{t}+1$ are matched with accounting data of fiscal year-end in $\mathrm{t}-1$. Table 1 reports summary statistics for our dataset.

[Insert Table 1 about here]

The firms in the sample have an average age of 19 years, ranging from very young to established firms. The overall tangibility of firms- captured as R\&D expenses over total assets - has a mean of 0.086 ranging from an absent level of $\mathrm{R} \& \mathrm{D}$ to a much higher $\mathrm{R} \& \mathrm{D}$ expense to assets. The book-tomarket is computed as book value of common equity over the market cap and for the sample examined it reaches a maximum value of 18.366 and a sample mean of 0.71 .

\subsection{The Credit Cycle}

Perez-Quiros and Timmermann (2000) refer to "credit conditions" and use macroeconomic proxies such as the one-month T-Bill rate and changes in money stock to capture unfavorable credit levels. Lamont, Polk and Saa-Requejo (2001) look at the degree of financial constraint within firms but do not consider the interaction between the economic setting and financial constraints. Considering credit data directly is critical given recent trends in the US credit level and the significant effect credit shocks have on the economy (Bernanke, 1983; Mishkin, 1978). Data gathered by the Federal Reserve Bank of St. Louis shows that since the early 1990s total outstanding consumer credit in the US grew by more than $225 \%$, at an average rate of $11.25 \%$ per year. A similar trend is observed in total bank credit at all commercial banks.

\footnotetext{
${ }^{2}$ Firm-year observations with total assets, property plant and equipment, stockholders' equity, capital expenditures and R\&D expenditures equal to or less than zero are also dropped from the sample.
} 
We identify periods of high and low credit to capture the direct impacts of credit changes on the financial and macroeconomic setting. Several methods have been applied to capture the departure of credit from its equilibrium level. Mendoza and Torres (2008) identify credit booms and busts across emerging and industrial economies. The authors adopt a threshold method along with the standard Hodrick-Prescott filter to separate the cyclical and trend component of annual credit per capita. Credit booms (busts) are then defined as periods of large expansions (contractions) of credit compared to its long-run trend. Their use of annual data, however, limits the extent to which periods of high vs. low credit can be identified - Mendoza and Torres find that the United States experienced excessive credit only once, in $1999 .^{3}$

In this paper, the credit cycle is identified in two steps. We capture deviations from the credit level by detrending total credit through a linear regression on a time component. This choice is motivated by its simplicity in capturing the deviations from the credit level. ${ }^{4}$ Total credit is the series of monthly bank credit of all commercial banks from the Federal Reserve Bank of St. Louis dataset. The series is published by the Federal Reserve Bank on a weekly basis, every Friday, as part of the Assets and Liabilities of Commercial Banks report (H.8 release). The assets included in the series are securities, loans and leases in bank credit. The total commercial banks credit level through the sample period has a minimum of $\$ 610.84$ billion to a maximum of $\$ 11,674.40$ billion. We examine credit from the banking sector since previous literature finds that small, opaque firms rely mostly on private borrowing rather than debt from the open market. Figure 1 provides a graphical representation of the credit residuals obtained and shows the cyclical component of the total credit

\footnotetext{
3 We decide not to adopt the HP filter in our study given Hamilton's (2017) recent criticism on this methodology. Hamilton finds that an HP filter fails to produce a stationary component and it adds spurious relations not fond in the original data.

${ }^{4}$ In unreported results we capture the credit cycle by adopting a Hodrick-Prescott filter methodology similar to Mendoza and Torres (2008). Results are qualitatively robust.
} 
level along with NBER recessions. Recessions seem to coincide with negative or decreasing credit residuals.

[Insert Figure 1 about here]

We then capture high or low credit regimes through a multivariate Markov regime-switching model with either constant or time varying probabilities as adopted in Perez-Quiros and Timmermann (2000). Our procedure differs from Perez-Quiros and Timmermann in that the regime switching probabilities are functions of the deviations from a credit trend allowing the regimes to equally apply to all the opaque portfolios analyzed.

Sources of funds beyond commercial banks credit - such as the financing through the shadow banking channel - might also be of importance in our context. However, the ease of access to other financing channels is still dependent on firm's nature and characteristics. Opaque firms face a higher cost of financing diversification and have overall higher fixed financing costs. Furthermore, the presence of a shadow banking channel in the United States has developed parallel to the amount of commercial credit in the banking sector. The volume of financial intermediary sources is of similar magnitude to the amount of credit from traditional banking channels (Pozsar, Arian, Ashcraft and Boesky, 2010). For these reasons, we believe it is sufficient to concentrate our analysis on the credit cycle involving traditional banking channels and available commercial credit. The impact of shadow banking on the availability of credit to firms in the corss-section could be venue for further research.

\section{$\underline{4.2 \text { Opacity }}$}

The "opacity premium" is observed when opaque assets offer returns in excess of transparent asset returns, even though the final expected payoff is the same (Sato, 2013). This is caused by the difficulty in determining the value of firms with short earning history, intangible assets, unstable dividends, and low profitability (Baker and Wurgler, 2006). Investors will demand a premium for 
holding stocks of firms whose values are uncertain due to the lack of information on the firm profitability.

While there is a common view concerning the definition of opacity, there is no agreement when it comes to its measurement and various proxies have been used in order to capture a firm's degree of opacity. Taking into account the different sources of opacity in the construction of the index allows us to capture the overall credit-sensitive nature of the firm.

To capture firm opacity, we follow the spirit of the Baker and Wurgler (2006) sentiment index to construct a firm-level opacity index. On June of every year we run a principal component analysis in order to construct and compute the yearly opacity index for each firm. The index is constructed as a linear combination of the first principal component of the following variables: property plant and equipment over total assets (tang), log of age, log of size (price times shares outstanding), book-tomarket (BEME), R\&D expenditures over total assets $(R D)$, and discretionary current accruals (DCAJones) computed as in Jones (1991). ${ }^{5}$ The variable choice is supported by previous literature and by the fact that opaque firms tend to be volatile, small, young and intangible (Berger and Turtle, 2012).

Considering opacity as an index composed of several firm characteristics captures the overall level of opacity rather than a single component. The latter would bias the analysis and results by placing weight only on the firm's industry or product nature. We believe a principal component analysis to be the most appropriate methodology for the construction of the opacity index. This methodology examines the patterns across a set of variables and identifies linear relationships among them. Factor analysis is another methodology often adopted when exploring patterns across quantitative variables, but this procedure is most effective when explaining the covariance or

\footnotetext{
${ }^{5}$ Refer to Section 9 of the paper for the additional indices used in order to run our robustness checks.
} 
correlations of variables, rather than their total variance. Table 2 reports the computation of the opacity index for each year in the sample.

[nsert Table 2 about here]

Overall, we observe an increase in opacity with the following firm characteristics: intangibility, youth, smallness, financial constraints, and R\&D. The effects of book-to-market and discretionary current accruals for respectively $40 \%$ and $44 \%$ of the years in the sample have the opposite sign we expected. This result can be explained by the dual nature of the two firm characteristics: book-to-market also captures the value intrinsic to the firm but not visible to the investor, and discretionary accruals captures opacity through earnings managements or through characteristics intrinsic to the firm. Because in the principal component analysis discretionary accruals explain the smallest portion of common variation among opaque firm characteristics examined, as a robustness check we compute the opacity index omitting this variable and find that excess returns patters across opaque portfolios are consistent with our original analysis. We therefore decide to include discretionary accruals even though the effect is not consistent because this procedure allows us to create a more comprehensive opacity measure.

The same robustness check approach cannot be adopted to control for the change in sign of book-to-market. As a matter of fact, book-to-market explains a significant portion of the common variation among variables examined and omitting it would leave unexplained a critical portion of the common variation among opaque variables. Nonetheless, the book-to-market switch in sign can be explained through economic intuition. We expect a higher BEME to coincide with a lower firm's opacity because a high book-to-market ratio captures firms with higher infrastructure capital (for example, manufacturing rather than consulting-type firms) and with higher expected future cash flows (Pontiff and Schall, 1998). On the other hand, it could also capture a portion of the actual value of the firm which is not perceived by the market due to a higher opacity, therefore causing a 
higher BEME to coincide with a higher opacity level. The appearance of both positive and negative effect on the overall opacity index across the sample period can thus be justified.

Overall, the average index and impact of the opaque characteristics reflect our expectations and can be represented as follows:

$$
\begin{aligned}
\text { Average_OpacityIndex }_{\mathrm{t}}=- & 0.42307 \mathrm{Tang}_{t}-0.57265 \log _{-} \text {Age }_{t}-0.43702 \operatorname{LogSize}_{t} \\
& -0.05383 \mathrm{BEME}_{t}+0.40330 \mathrm{RD} \mathrm{D}_{t}+0.00071 \mathrm{DCAJones}_{t} .
\end{aligned}
$$

Firm age is computed as the log of the current age of the firm calculated since its first appearance on COMPUSTAT. Smaller firms are usually younger firms. We expect older firms to have lower excess returns than younger firms, as seen in Perez-Quiros and Timmermann and Fama and French. Size captures the size-effect that is central to Perez-Quiros and Timmermann (2000) argument we refer to. Following common practice, we capture size as price times shares outstanding.

Hutton, Marcus and Tehranian (2009), Bhattacharya, Daouk and Welker (2003) and Hirshleifer, Hou and Teoh (2009) use earnings management as a firm-level measurement of opacity arguing for its direct connection to manager attempts to hide information from the public. Hutton, Marcus and Tehranian find that opacity is associated with a higher R-squared obtained when regressing individual stock returns on CRSP value-weighted market index and Fama-French value-weighted industry index. A higher R-squared indicates less disclosure of firm-specific information: the lack of public information should cause stock returns to mirror market indexes.

Bhattacharya, Daouk and Welker (2003) identify three components of earnings management: loss avoidance, earnings smoothing, and earnings aggressiveness. Their measurement aims at capturing how little information lies in a firm's reported earnings about its true performance and future value. Opacity is therefore a consequence of asymmetric information, which increases transaction costs and induces investors to require higher returns. 
The modified Jones (1991) discretionary current accruals model is the most appropriate in detecting earnings management (Dechow, Sloan and Sweeney, 1995.) Jones captures discretionary accruals as the difference between total current accruals and nondiscretionary current accruals. ${ }^{6}$

Another single proxy of opacity is research and development expenditures as a percentage of assets. R\&D intensive firms are considered riskier, less tangible and highly opaque because the outcome of the firm's investment decisions is unknown. Chan, Lakonishok and Sougiannis (2001) find that firms with a high $\mathrm{R} \& \mathrm{D}$ to equity market value ratio experience more volatile returns and larger excess returns. Furthermore, R\&D intensive firms are usually small, young, do not pay dividends and are highly leveraged. Li (2011) confirmed these findings and connects Lamont, Polk and Saa-Requejo (2001) research questions to the level of firm R\&D. Li captures a strong positive relationship between financial constraints and stock returns of $R \& D$ intensive firms, as well as between R\&D investments and stock returns of more constrained firms. The positive R\&D-returns relationship can be attributed to financial constraints because this relationship is stronger in more constrained firms. Li suggests that financial constraints drive the positive R\&D-return relation, play a role in determining firm's value, and have a significant impact on R\&D-intensive firms' risk and return. Lastly, earnings management and R\&D capture opacity that arises because of the firm's industry (such as high tech, pharmaceutical, service) and opacity that arises because of management decisions and accounting practices (such as earnings management, loss avoidance, earnings smoothing, and earnings aggressiveness).

After computing a yearly opacity index we can investigate the time-series dynamics of firm opacity levels in the aggregate. Figure 2, Panel A shows the average opacity index over time.

[Insert Figure 2 about here]

${ }^{6}$ See Dechow, Sloan and Sweeney (1995) for a detailed description of the computation of the modified Jones (1991) discretionary accruals. 
Interestingly, the overall level of firm opacity experiences a significant spike around the early 2000s, coinciding with the dot-com bubble experienced in the stock market. It is safe to say this spike is caused by the increased number of small, high R\&D, intangible companies that characterized the stock market of that period. These are characteristics that increase the opacity of a firm, and the significant larger number of opaque firms listed on the stock market causes the average index to increase. Besides the increase in the early 2000s, the average opacity experiences several increases and decreases in its level.

In order to refrain from placing too much weight on the firm's stock price, we compute an alternative opacity index with size captured as a firm's total current assets. The results of our analysis are robust despite the choice of the opacity index. ${ }^{7}$ Figure 2, Panel B represents the average yearly opacity index with size as total assets. The firm opacity level is overall more stable than the index including market cap. However, both indices capture the opacity increase in the early 2000s and a decrease in overall opacity thereafter. Because our results are robust despite the choice of the index, we choose to use the index with market cap in order to be in line with common procedure in the previous literature.

\section{Portfolio analysis}

The first task is to construct portfolios across the opacity index in order to investigate the difference in excess returns. We also construct portfolios across size and financial constraint levels in order to verify the presence of the size effect in Perez-Quiros and Timmermann (2000) and of the financial constraint effect in Lamont, Polk and Saa-Requejo (2001). Results support the presence of an opacity premium and the inclusion of smallness and access to credit sensitivity measures in the opacity index.

\footnotetext{
${ }^{7}$ See section 9 for a discussion on robustness checks and procedures adopted.
} 


\subsection{Opaque Portfolios}

We sort firms in ascending order according to their opacity index and construct both tercile, quintile, and deciles portfolios from low to high opacity following Fama and French (1992). Portfolios are formed by ranking all available NYSE-AMEX-NASDAQ firms by the opacity index in each June of year $t$ from 1973 to 2015 . Table 3, Panel A reports summary statistics of firm characteristics for quantile portfolios constructed on the opacity index. Opaque firms are small, young, less tangible, more R\&D intensive, have a higher book-to-market ratio, and experience the highest degree of earning management and riskier opportunities. For this reason, the index includes proxies of tangibility, available information, profitability, growth opportunity and earning management of a firm.

\section{[Insert Table 3 about here]}

On average, each portfolio has little over 200 firms per year, with the most opaque firms being the most abundant portfolio with 244 firms on average. As expected, the most opaque firms are the smallest, youngest, less tangible, and most R\&D intensive firms. A higher book-to-market ratio indicates a higher risk as in Fama and French $(1992,2006)$, and a larger absolute value earnings management indicates uncertainty and asymmetric information (Bhattacharya, Daouk and Welker, 2003).

Table 3, Panels B and C report the equal-weighted average monthly returns of portfolios across opacity levels. For the quintile (decile) case reported in Table 2, Panel B the bottom 20\% (10\%) of firms are most transparent, while the top 20\% (10\%) includes the most opaque firms. In both the quintile and decile case, highly opaque firms experience higher average returns compared to transparent firms. The highest quintile (decile) experiences a 147 (196) basis points premium compared to the lowest quintile (decile). 
As a robustness check, we constructed quintile portfolios based on one single characteristic: the ratio of $\mathrm{R} \& \mathrm{D}$ expenditures to total assets. We order firms in ascending order according to their R\&D-to-assets ratio reported in dollar amounts. The bottom $20 \%$ collect firms with the lowest R\&D investment and will be classified as the least opaque firms, the top $20 \%$ instead refer to highly opaque firms. Portfolios are constructed according to such classification. Unreported results show that the equal-weighted average monthly returns for the opaque portfolios constructed on R\&D to total assets have the same pattern as the portfolios constructed on our composite index. R\&D intensive, opaque firms have higher average returns than transparent firms.

\section{$\underline{5.2 \text { Size Portfolios }}$}

The size-effect is central to Perez-Quiros and Timmermann (2000) argument and it is one of the most robust anomalies found in empirical asset pricing tests (Fama and French, 1989, 1992, 1993). We construct two and five quantile value-weighted size portfolios following Fama and French procedure where the size breakpoints for year $t$ are the NYSE median and quintiles of market equity at the end of June of year $t-1$. We then sort all firms from NYSE, AMEX, and NASDAQ in ascending order according to their market cap. Size portfolios constructed on the market cap median are used to form portfolios on multiple firm characteristics.

Table 4, Panels A and B report the average monthly returns for equal-weighted portfolios (median and quintile) taking into consideration the entire sample from January 1973 to December 2015 available on CRSP. As in Fama and French (1992) we capture the negative relationship between size and returns of equal-weighted portfolios.

[Insert Table 4 about here] 


\section{$\underline{5.3 \text { Financially Constrained Portfolios }}$}

Given that opacity entails limited access to external sources of funds, controlling for financial constraints characteristics could be of significance in our study. As measures of a firm's financial constraint level, we adopt Whited and Wu's (2006) WW index and Kaplan and Kingales' (1997) KZ index.

We sort firms in ascending order according to either their WW or KZ index and we construct median portfolios from low to high financial constraints following Fama and French's (1992) procedure. Table 4, Panels $\mathrm{C}$ and $\mathrm{D}$ report the equal-weighted average monthly returns of median portfolios across financial constraint levels. We chose the median cutoff for the construction of combination portfolios following Fama and French's procedure.

Average returns for annually rebalanced equal-weighted portfolios are formed by ranking all available NYSE-AMEX-NASDAQ firms by the respective financially constraint index in each June of year t from January 1973 to December 2015. The financial constraint breakpoint for year $\mathrm{t}$ for portfolios in Panel C is the NYSE-AMEX-NASDAQ median of the WW index at the end of June t1; Panel D reports the portfolios constructed over the $\mathrm{KZ}$ index.

Financially constrained firms experience higher average returns compared to firms less constrained no matter the financial constraint index used in the portfolio construction. This result is in line with Perez-Quiros and Timmermann's (2000) argument and in contrast with Lamont, Polk and Saa-Requejo's (2001) findings that financially constrained firms earn lower returns than unconstrained firms and are not particularly exposed to credit conditions.

\section{$\underline{5.4 \text { Combination Portfolios }}$}

\subsubsection{Portfolios Constructed as a Combination of Opacity Level and Size}

Opaque firms are mostly small firms. We control for the size effect by forming portfolios on both firm's size (price times shares outstanding) and opacity levels. Portfolio construction follows 
Fama and French (1992) procedure. The size breakpoint for year $\mathrm{t}$ is the NYSE $50^{\text {th }}$ percentile at the end of June $t-1$. The opacity index breakpoint for year $t$ is the NYSE median or $30^{\text {th }}$ and $70^{\text {th }}$ percentiles of the index at the end of June $\mathrm{t}-1$. Table 5, Panel A reports the equal weighted average returns for the annually rebalanced combination portfolios on opacity and size. The pattern of portfolio returns suggests that overall opacity is most the most crucial characteristic of a firm even when size is kept constant. Across firms of the same size, the opaque firms will experience the highest excess returns, while the transparent firms will experience the lowest excess returns. Opacity seems to have a more significant impact than size.

[Insert Table 5 about here]

We also construct portfolios on size and opacity, where the size factor in the opacity index is captured through total current assets. This avoids accounting for size - as market cap - twice and it highlights even more the impact of opacity. Return patters are robust no matter which size proxy is adopted.

Another approach used to avoid accounting for size twice would be to create an opacity index which excludes the size characteristic. Despite the straightforward solution, not considering size in the index significantly skews the opacity measurement because it ignores one of its major characteristics of what it is considered to be an opaque firm. ${ }^{8}$

\subsubsection{Portfolios Constructed as a Combination of Opacity and Financial Constraint Levels}

We construct portfolios as a combination of opacity and financial constraint levels in order to capture the relative impact of both firm characteristics on firm returns. Combination portfolios are formed as the intersection of median portfolios formed on the $\mathrm{KZ}$ financial constraint index and tercile portfolios formed on the opacity index. Portfolio construction follows Fama and French

${ }^{8}$ The analysis using an index without size, not reported in the paper, significantly changes the return patterns and non-consistent results across different models. Furthermore, ignoring size from the index departs from the overall research question of our paper. 
(1992) procedure. The KZ index breakpoint for year $t$ is the NYSE-AMEX-NASDAQ $50^{\text {th }}$

percentile at the end of June $\mathrm{t}-1$. The opacity breakpoint for year $\mathrm{t}$ is the NYSE-AMEX-NASDAQ

median or the $30^{\text {th }}$ and $70^{\text {th }}$ percentiles at the end of June t-1. Table 5, Panel B reports the equal

weighted average returns for the annually rebalanced combination portfolios on opacity and

financial constraint levels. The opacity and $\mathrm{KZ}$ indices have a correlation coefficient of 0.35 ,

showing that they are positively related but they do not capture the same firm characteristics given

the rather low correlation. Considering both characteristics therefore will not count for the same

effect twice.

The pattern of portfolio returns shows that opaque, financially constrained portfolios experience the highest excess returns. Unconstrained firms experience an opacity premium of about 91 basis points, while constrained firms experience an opacity premium of about 126 basis points. However, holding opacity constant, firms experience only 52 basis points in financial constraint premium.

The degree of opacity seems to be the most influential characteristic of a firm and it includes both smallness and access to credit sensitivity measures.

\section{Opaque-Minus-Transparent Factor}

In order to capture the premia related to opacity, we calculate an opacity factor, the OMT (Opaque-Minus-Transparent) factor, as the difference between the most opaque and the most transparent portfolio returns. The opacity breakpoints were the $10^{\text {th }}$ and $90^{\text {th }}$ percentiles of the opacity index at the end of June t-1. Figure 3 shows the OMT factor over time.

[Insert Figure 3 about here] 
The series has high volatility with the largest swings occurring between the years 2000 and 2001 corresponding to the stock market dot-com bubble. The time series dynamics follows a pattern similar to the opacity index, once more highlighting the premium implied by a firm's opacity level. ${ }^{9}$

\section{$\underline{6.1 \text { Linear analysis and results }}$}

In order to examine the effect of opacity on excess returns and have a first test of our hypotheses, we run ordinary least square regressions across firms. Table 6 reports the results for six modifications of the following panel linear regression:

$$
r_{\mathrm{i}, \mathrm{t}}=\beta_{0}+\beta_{1} M K T_{\mathrm{t}}+\beta_{2} S M B_{\mathrm{t}}+\beta_{3} H M L_{\mathrm{t}}+\beta_{4} O M T_{\mathrm{t}}+\beta_{5} \text { Dummy }_{\mathrm{t}}+\beta_{6} \text { CreditGrowth }_{\mathrm{t}-1}
$$

where monthly excess returns, $r_{i}$, are calculated as the difference between firm's monthly returns and the one-month Treasury Bill rate; OMT is the opacity factor; Dummy captures periods of low credit and it equals 1 in periods of credit level below the trend, and 0 otherwise; CreditGrowth is the growth in credit residuals from regressing the natural logarithm of total bank credit of all commercial banks on a time trend.

[nsert Table 6 about here]

The OMT factor has a positive, significant impact on excess returns showing that as the opacity premium increases, the firm's excess returns increase as well. ${ }^{10}$ The standardized regressions of Table 6 shows that a one standard deviation increase in the OMT factor leads to 0.085-0.086 standard deviations increases in excess returns. Results from Models 2 and 4 show that being in a period of credit levels below the trend negatively affects the returns of all firms. However results from Models 3 and 5 show that a decrease in credit positively impacts firm's returns: one standard deviation decrease in credit positively impacts the excess returns by 0.011 to 0.016 standard deviations. These

\footnotetext{
9 The dynamics of the OMT factor are robust when the premium is calculated using the opacity index with size as total current assets.

${ }^{10}$ Results are consistent when calculating the OMT factor using different percentile breakpoints, $30^{\text {th }}$ and $70^{\text {th }}$.
} 
might seem contrasting results, but a more careful interpretation suggests differently. Returns are negatively affected in a period where credit is low due to the overall stringent economic conditions and, at the same time, a tightening of credit reflects a riskier condition that needs to be compensated with higher excess returns.

We run a similar analysis across opaque portfolios to explore the underlying interpretation and the effect of credit on excess returns across opacity levels. Table 7 reports the results for the following three models across opaque portfolio quintiles:

$$
\begin{gathered}
r_{\mathrm{t}}^{i}=\beta_{0}^{i}+\beta_{1}^{i} \text { CreditGrowth }_{t-1}+\beta_{2}^{i} M K T_{\mathrm{t}}+\beta_{3}^{i} S M B_{\mathrm{t}}+\beta_{4}^{i} H M L_{\mathrm{t}} \\
r_{\mathrm{t}}^{i}=\beta_{0}^{i}+\beta_{1}^{i} \text { Dummy }_{t}+\beta_{2}^{i} \text { CreditGrowth }_{t}+\beta_{3}^{i} \text { Dummy }_{t} * \text { CreditGrowth }_{t}+\beta_{4}^{i} M K T_{t-1}+\beta_{5}^{i} S M B_{\mathrm{t}}+\beta_{6}^{i} H M L_{\mathrm{t}} \\
r_{\mathrm{t}}^{i}=\beta_{0}^{i}+\beta_{1}^{i} \text { Dummy }_{t}+\beta_{2}^{i} \text { CreditGrowth }_{t}+\beta_{3}^{i} \text { Dummy }_{t} * \text { CreditGrowth }_{t}+\beta_{4}^{i} M K T_{t-1}+\beta_{5}^{i} H M L_{\mathrm{t}}
\end{gathered}
$$

for $i=\{1,2,3,4,5\}$ where $r_{t}$ is excess returns on the portfolio measured as the difference between portfolio return and the one-month Treasury Bill rate; Dummy is a dummy variable capturing periods of low credit; CreditGrowth is the growth in credit residuals from regressing the natural logarithm of total bank credit of all commercial banks on a time trend; and Dummy*CreditGrowth is the interaction variable between being in a low credit state and credit growth.

$$
\text { [Insert Table } 7 \text { about here] }
$$

Results in Table 7, Panel A confirm that a tightening of credit has a positive impact on excess returns. The positive effect is significantly greater for portfolios of opaque firm, leading to an increase of 0.03 standard deviations. The market, size and value factor all significantly impact excess returns across opacity level. The size factor has a stronger impact for opaque firm returns, and its effect decreases as opacity decreases. The inverse is true for the market factor, where it is most important for transparent firms.

Panel B takes into account for the interaction term of the credit state and its growth. Opaque firms are significantly, negatively affected by the interaction variable to a greater degree than 
transparent firms. Opaque and transparent firms are affected differently. A further decrease in credit in a period of tight conditions will lead to higher excess returns for opaque firms relative to transparent firms. The effect of overall credit conditions, captured by Dummy, and of a change in credit growth have consistent effect across portfolios, but the impact is always greater in absolute value for opaque firms. Both Panels A and B report a lower R-squared for opaque portfolios, indicating that there are additional elements driving their excess returns, while the R-squared for transparent firms is, as expected, rather high.

In Panel $\mathrm{C}$ we omit the size factor in order to investigate the effect on excess returns driven by size. This decision is motivated by the construction of the opacity index, which includes a size characteristic. The impact of credit growth and the interaction term is greater in magnitude for opaque portfolios compared to the results of Panel B, however the impact of credit conditions on transparent firms decreases when compared to the previous analysis with the inclusion of size. Lastly, the R-squared are lower across all portfolios. We can safely say that size is not the major driver of excess returns, but it does play a role because it is one of the factors determining the level of opacity of a firm.

Testing our hypotheses by running ordinary least square regressions on all firm-year observations provides preliminary results that are easy to interpret and in line with our predictions. However, linear analysis cannot fully explain the dynamics behind the excess returns of opaque portfolios. Given the nonlinear nature of our research question, a linear analysis might be overlooking some dynamic patterns across portfolios and credit cycle. 


\section{The Nonlinear Model}

A decrease in the amount of credit available influences the behavior of private lenders who become less likely to lend to riskier borrowers. Consequently, because opaque firms are riskier than transparent firms, opaque firms will be more sensitive to the credit cycle.

The relationship between credit and the returns of opaque firms is not necessarily linear because periods of low credit are more critical and pervasive than periods of excess credit. Economic activity and investment are in fact significantly limited in the former case (Davig and Hakkio, 2010). We expect the relationship between credit and excess returns across opaque portfolios to be best represented by a nonlinear model capturing both the different effects of the credit cycle and its linkages with opacity and required excess returns.

We adopt a multivariate Markov switching framework to account for the different credit regimes of the model (low credit state vs. high credit state). Like most macroeconomic and financial series, credit is characterized by changes in level. The economy could go from a period of high credit to a period of low credit, but the economy would not be able to know the specific credit regime at any given time. A Markov switching model allows us to examine the behavior of variables across states, estimate the probability of being in a high or low credit state, and derive the likelihood of a transition from one state to the other. The model will therefore capture nonlinear time-series dynamic patterns characterized by multiple structures and allow for the parameters to differ across latent states. The states are unobservable and follow a first order Markov chain with time varying transition probabilities. Estimated probabilities are determined only by the data, are not enforced on the results, and they indicate the likelihood, not the certainty, of being in a particular state.

In our study credit is the main determinant of the latent states. Following Perez-Quiros and Timmermann (2000), Hamilton (1989), and Gray (1996) we adopt a model with time-varying transition probabilities. However, we choose to run multivariate regime switching models in order to 
admit multiple states of the world that equally apply to all portfolios. The coefficients in our model vary across states and are estimated through maximum-likelihood. ${ }^{11}$ Based on the constant probability model outlined in Perlin (2015), the final log likelihood function used in the estimation of our model after obtaining the time-varying state transition probabilities is the following:

$$
\ln L=\sum_{t=1}^{T} \ln \sum_{j=1}^{2} \ln \left(f\left(r_{i, t} \mid S_{i, t}=j, \Theta\right)\right) \operatorname{Pr}\left(S_{i, t}=j \mid \psi_{t}\right)
$$

where $\left(f\left(r_{i, t} \mid S_{i, t}=j, \Theta\right)\right)$ is the likelihood function for state $j$ dependent on a set of parameters $\Theta$, $\operatorname{Pr}\left(S_{i, t}=j \mid \psi_{t}\right)$ is the probability for each state and $\psi_{t}$ is the matrix of available information at time t. The overall likelihood function is the weighted average of the likelihood function in each state.

Our general empirical model admits time varying transition probabilities related to the cyclical component of total bank credit of all commercial banks, CreditResiduals. Our general multivariate model, Model A, is a can be written as:

\section{MODEL A:}

$$
\begin{aligned}
& r_{\mathrm{t}}^{i}=\beta_{0, s t}^{i}+\beta_{1 i, s t}^{i} \text { 1moTBill }_{t-1}+\beta_{2, s t}^{i} \text { Def }_{\mathrm{t}-1}+\beta_{3, \mathrm{st}}^{\mathrm{i}} \text { DividendYield }_{\mathrm{t}-1}+\varepsilon_{t}^{i} \\
& p_{\mathrm{t}}^{i}=\beta_{0}^{i} \mathrm{P}\left(\mathrm{S}_{t}^{i}=1 \mid \mathrm{S}_{t-1}^{i}=1, Y_{t-1}\right)=\phi\left[\prod_{0 i}+\prod_{1 i}\left(\text { CreditResiduals }_{t-1}\right)\right] \\
& q_{\mathrm{t}}^{i}=\beta_{0}^{i} \mathrm{P}\left(\mathrm{S}_{t}^{i}=2 \mid \mathrm{S}_{t-1}^{i}=2, Y_{t-1}\right)=\phi\left[\prod_{2 i}+\prod_{3 i}\left(\text { CreditResiduals }_{t-1}\right)\right]
\end{aligned}
$$

where $r_{i, t}$ is the excess return of the $i$ th opaque portfolio quintiles; $S_{t}=\{1,2\}$, $p_{i t}$ is the probability of being in State 1 at time $t$ given that we were in State 1 at time $t-1$; $q_{i t}$ is the probability of being in State 2 at time $t$ given that we were in State 2 at time $t-1 ; \phi$ is the cumulative density function under the normality assumption; and $\varepsilon_{\mathrm{t}}^{\mathrm{i}} \sim \mathrm{N}\left(0, \sigma_{\mathrm{i} 0, \mathrm{st}}^{2}\right)$. The different economic and regime conditions are captured by allowing for both the coefficients and the variance of the model to vary across states.

\footnotetext{
${ }^{11}$ We gratefully acknowledge Matlab code from Ding (2012) and Perlin (2015) to estimate a Markov regime switching model through maximum likelihood for both constant and time varying transition probabilities.
} 
The choice of specific control variables is motivated by previous work. The three-month Treasury bill (3moTbill) captures investors' expectations on future economic activity. The default premium $(D e f)$ is the difference between yields on BAA- and AAA-rated corporate bonds capturing the quality spread. This variable captures financial distress of firms in period of economic downturn. A higher risk of default will be compensated by higher excess returns. The computation of dividend yields (DividendYield) follows Fama and French's (1988) dividend to price ratios, where firm’s dividends are the total dividends paid from July of $t-1$ to June of $t$.

We apply restrictions to our general model in order to create two narrower specifications: (i) the time-varying transition probabilities are driven only by a constant and credit enters the model as an explanatory variable (Model B); (ii) the state transition probabilities are constant and credit enters the model as an explanatory variable (Model C). The state transition probabilities for Models B and C are respectively:

MODEL B:

$$
\begin{aligned}
p_{i t} & =\mathrm{P}\left(S_{i, t}=1 \mid S_{i, t-1}=1, Y_{t-1}\right)=\phi\left[\prod_{0 i, s t}\right] \\
q_{i t} & =P\left(S_{i, t}=2 \mid S_{i, t-1}=2, Y_{t-1}\right)=\phi\left[\prod_{1 i, s t}\right]
\end{aligned}
$$

\section{MODEL C:}

$$
\begin{aligned}
& p_{i}=\mathrm{P}\left(S_{i, t}=1 \mid S_{i, t-1}=1, Y_{t-1}\right)=\phi\left[\prod_{0 i}\right] \\
& q_{i}=P\left(S_{i, t}=2 \mid S_{i, t-1}=2, Y_{t-1}\right)=\phi\left[\prod_{0 i}\right]
\end{aligned}
$$

where $\phi$ are the cumulative density function under the normality assumption.

The time-varying component in Models A and B takes into account the impact of credit on the probability of switching regimes. In Model B the state transition probability are time varying and determined by a constant, while in Model $\mathrm{C}$ the state transition probabilities are not time variant such that $p_{i t}=p_{i}$ and $q_{i t}=q_{i}$. Overall, the three models allow (1) the regime state to determine 
the transition between the states of the world, (2) the parameters to change with shifts in regimes over time, and (3) the excess returns to be ruled by two distributions with distinct means, variances and intercepts. Lastly, the regime state determines the transition between the two regimes.

\section{Nonlinear Results}

As an initial analysis we run the general multivariate model, Model A, where a regime switching model is estimated across opaque quintile portfolios. A multivariate analysis simultaneously takes into account the information provided by each portfolio in order to estimate the likelihood and the presence of different regimes. A univariate approach is not able to consistently capture separate regimes when each portfolio is analyzed individually. ${ }^{12}$ The univariate model in fact estimates the state probability for each portfolio determining the likelihood of State 1 or State 2 using only information from the individual portfolio analyzed. For this reason a univariate analysis is too restrictive when examining the effect of credit across all portfolios.

Table 8 reports the results for Model A across opaque portfolio quintiles. ${ }^{13}$ The likelihood ratio test confirms significantly different parameter estimates across the two states. The duration of regimes is short: slightly less than three months for State 1 and slightly more than two months for State 2 . Both the constant and the credit cycle in the transition probability equation have a negative impact in State 2.

[Insert Table 8 about here]

When compared to the transparent portfolio, the opaque portfolio has overall higher variances and all parameter estimates are larger in absolute value in both states, with the exception of the

\footnotetext{
${ }^{12}$ In unreported results, through a likelihood ratio test of the univariate model we fail to reject the null that the parameter estimates across regimes are significantly different. This was an expected results given the univariate component of the analysis and the nonlinear, multivariate component of our research question. ${ }^{13}$ We obtain consistent results across opaque portfolio deciles.
} 
default premium. The qualitative impact of parameters are consistent across quintile portfolio. However, opaque firms seem to have a higher sensitivity than transparent firms. Opaque firms have a positive, larger intercept in State 1 and a negative, smaller intercept in State 2. The effect of the one-month T-bill rate has a negative impact in State 1 and a positive impact in State 2 across all portfolios.

A multivariate analysis across too many portfolios causes the model to be less precise due to the simultaneous estimation of a very large number of parameters - 57 parameters in the quintile case. A bivariate model that simultaneously considers only the highest and the lowest opaque portfolios estimates a lower number of parameters allowing for more precision in the transition probability estimation. Table 9 reports the bivariate version of two regime switching models (Models A, B and C) analyzed across two decile portfolios, each having the lowest or the highest opacity index level. Parameter estimates are significantly different across states for all three models, with a likelihood ratio test statistical significance at the $2 \%, 3 \%$, and $2 \%$ levels, respectively.

[Insert Table 9 about here]

The state transition probabilities in Table 9, Panel A are ruled by a constant and by the credit cycle: State 1 has a positive, larger intercept impact and a positive credit cycle impact, while State 2 has negative intercept and credit cycle impacts. The State 2 is once again the low mean, high variance, shorter duration state. State 1 lasts slightly more than 9 months, while State 2 lasts slightly more than 4 months. Figure 4 plots the State 2 probabilities estimated from Model A along with the recession periods determined ex-post by the NBER. The sate probabilities at time $t$ are conditional on the information at time $t-1 .{ }^{14}$

[Insert Figure 4 about here]

\footnotetext{
${ }^{14}$ In order to verify that the model is capturing states of the world with different credit conditions rather than the business cycle, we graph the State 2 probabilities for Model B, where credit enters the model as an independent variable. Results are robust with Model A transition probabilities depicted in Figure 4.
} 
A regime switching model estimates the characteristics and likelihood of each state, it does not estimate with certainty the identity of each regime. In order to identify the low credit and the high credit regime there is the need to interpret the characteristics of each state through economic theory and intuition. A low credit state has a higher uncertainty and it usually occurs around recessionary periods and economic downturns. Figure 4 shows that each NBER recession coincides with a high probability of being in State 2. Figure 5 shows the State 2 probabilities along with the Chicago Fed National Activity Index (CFNAI). The CFNAI represents the level of monthly economic activity and it is computed as a combination of eighty-five macroeconomic series. A low CFNAI value corresponds to low economic activity. Periods of high State 2 probabilities coincide with periods of low CFNAI values; State 2 can be interpreted as the state when the credit level is most likely to be low.

\section{[Insert Figures 5 about here]}

Lastly, Figure 6 further highlights the identification of State 2 as the low credit regime. The figure plots the State 2 probabilities along with the credit spread computed as the difference between AAA corporate bond yield and the 10-year Treasury yield. The credit spread is often regarded as a proxy for credit conditions, credit risk, and external finance premium. Peaks of high credit spread correspond to periods having a high State 2 probability.

\section{[Insert Figures 6 about here]}

After analyzing the relation between the estimated State 2 probabilities and the NBER recessions, the CFNAI, and the credit spread, we can interpret State 2 as being the regime in our model when credit level is most likely to be low. Along with our hypothesis, results show that the opaque portfolio has a significantly higher variance in State 2 when compared to the transparent portfolio. The higher variance can be interpreted as a decrease of stability in the state, a characteristic common to periods of low credit. 
Even though a univariate model is limiting because it analyzes each portfolio individually, it allows us to examine the probability dynamics across opaque portfolio quantiles. Figure 7 reports the smoothed state probabilities for the most transparent and most opaque decile portfolios. The two portfolios have similar probabilities, however the opaque portfolios have more pronounced and persistent State 2 probabilities. The figure highlights the difference in behavior across regimes due to different levels of opacity. Transparent firms, on the other hand, have lower probability of being in State 2 , even if this probability is recurring more often compared to opaque firm's state probabilities.

\section{[Insert Figure 7 about here]}

Figure 8 report the time-series of the probability of remaining in the current state - either high or low credit regime - for transparent and opaque portfolios deciles. Whereas both transparent and opaque portfolios have a rather constant and high tendency of remaining in State 1 (the high credit state), opaque portfolios have a much higher probability of staying in State 2. This time-series variation further justifies the adoption of a regime switching model with time-varying transition probability. The State 2 transition probabilities for both firms seem to mirror each other: a higher probability of staying in State 2 for an opaque firms corresponds to a lower probability of staying in State 2 for transparent firms. This further highlights the heterogeneous effect of credit across opacity levels.

\section{[Insert Figure 8 about here]}

Results in Panel A, Table 9 show that parameters are larger in absolute value for the highest portfolio decile, thus capturing the hypothesized higher sensitivity of opaque portfolios. The intercept for the opaque portfolio switches sign across states, going from negative to positive from State 1 to State 2. The one-month T-bill negatively affects the opaque portfolio in both states, but only in State 1 for transparent firms. Overall, for opaque portfolios the impact is greater in the low 
credit state and estimates are larger in absolute value due to credit's heterogeneous effects on excess returns.

[Insert Table 9 about here]

Panel B reports results for the bivariate model with the credit cycle entering the model as an explanatory variable and the transition probability being driven by a constant. Overall the results are consistent. The main punchline of Panel B is the interpretation of the credit variable across portfolios and states. State 2 is the high variance state, which can be identified with the low credit regime. The opaque portfolio is negatively affected by the credit level in State 2 but the impact is significantly smaller than State 1, the high credit state; the transparent portfolio are positively impacted in both states. The magnitude of the credit cycle estimate is larger for the opaque portfolio in both states when compared to the transparent portfolio parameters. The transition probability constant parameter is positive in State 1 but negative in State 2.

Panel C reports the results of the original model with a constant transition probability and with the credit cycle entering as an explanatory variable. Once again, we fail to reject the null of different estimates across regimes. State 2 is once again the shorter regime with higher variance. The transition probability is kept constant, but the impact across states is still greater in absolute value for opaque portfolios. Credit negatively impacts opaque firms during State 2, having an opposite effect when compared to the impact in State 1. Opaque firms experience a larger variance both in the cross-section and across states of the world. Despite the results are in line with our previous models and hypotheses, we believe keeping the transition probability constant is a limiting assumption that cannot be fully justified in a macroeconomic context. Allowing the transition probability to be time-varying is essential in identifying significantly different regimes and testing our hypotheses.

Results from Table 9 can be summarized as follows: 
Result 1. The excess returns of opaque portfolios have a higher sensitivity to credit conditions.

Result 2. State 2 is the high variance state and through economic intuition it can be interpreted as the low credit regime. State 2 is the regime with the shortest duration.

Result 3. Credit has a larger impact on opaque portfolios in State 2.

Result 4. An increase in the one-month Treasury bill rate negatively affects the excess returns of all portfolios in State 1, but positively in State 2.

Overall, we found a differential sensitivity to credit conditions across firms of different opacity level and an empirical support for our hypotheses. The two major findings are that i) firm's excess returns are more sensitive to unfavorable credit levels captured in State 2 (the low mean, high variance state) and that ii) opaque portfolios are more sensitive throughout the analysis when compared to transparent portfolios.

\section{Robustness Analysis}

We run robustness analyses using either (i) three alternative opacity indices, (ii) an alternative sorting procedure, (iii) an alternative credit variable, (iv) an alternative regime switching model specification, or (v) leverage as a control variable.

\subsection{Alternative computations of the opacity indices}

In order to refrain from placing too much weight on the price of a firm's stock we construct the yearly opacity index with size computed as total current assets. Total current assets in fact captures of a firm value of assets such as cash, accounts receivable, inventory and supplies that can be converted into cash in a one-year time frame. Total current assets is therefore a different proxy for a firm's size. The excess return patterns across different levels of the new opacity index reflect our original results: the most opaque firms experience higher excess returns compared to the most 
transparent firms. Furthermore, the regime switching model results are consistent and qualitative equal to our original analysis even if we create portfolios based on the new opacity index.

We also constructed a single index for the entire dataset by running a principal component analysis simultaneously considering data from June of every year. Results are qualitatively consistent with our original analysis. However, we believe a yearly construction of the index is more accurate and it is of use when explaining the time-series patterns of the opacity premium. Furthermore, a principal component analysis leads to most accurate results when analyzing a cross-sectional, rather than a panel, dataset.

Lastly, we constructed an opacity index without including size. The results are significantly different and non-consistent across different models. Ignoring size from the index departs from the overall research question of our paper. We believe that controlling for the size factor in our linear analysis and creating combination portfolios across size and opacity sufficiently highlights the opacity factors rather than size alone. We believe it is also necessary to include size in our analysis because size is correlated to public debt market access, a critical concept connected to opacity and our research question (Leary, 2009).

\subsection{An alternative sorting procedure for portfolios}

In our original analysis considered all available firms in order to take into account for the widest range of firm types. We sorted all available NYSE-AMEX-NASDAQ firms in ascending order according to their opacity index and constructed both quintile and deciles portfolios in each June of year $t$. As a robustness check, we follow Fama and French (1992) procedure and we consider only firms listed on the NYSE firms when ranking them according to their opacity index and calculating cutoff benchmarks.

As we predicted, considering only NYSE firms causes a larger number of firms to be assigned to the portfolios of the highest opacity levels. In unreported results we find that the most opaque 
portfolio has an average of 678 of firms, compared to an average 77 for the most transparent portfolio. This is in contrast with our original analysis where all portfolios have approximately the same average number of firms - 244 firms in the most opaque portfolio, and 203 firms in the most transparent portfolio.

This occurs because we are omitting a large portion of the most opaque firms listed on the NASDAQ exchange when the opacity breakpoints are calculated only using NYSE firms, as in the robustness check, ultimately skewing the breakpoints toward a lower opacity cutoffs. The NASDAQ firms have an overall higher average opacity index because they are small, high-tech firms and most of them therefore fall in the most opaque portfolio, consequently increasing the number of firms classified as opaque. Determining the opacity index quantile cutoffs by considering all firms in the sample eliminates this issue.

Our initial choice of considering all available firms when computing the portfolio cutoffs is the most appropriate one.

\subsection{An alternative regime switching model specification}

The identification of the states in a Markov-switching model might be driven by state-dependent variance returns. We control for this through a regime switching model with constant variance across states. Not allowing the variance to change across states might better capture the effect of the credit cycle on excess returns. Results are reported in Table 10, Panels A and B.

$$
\text { [Insert Table } 10 \text { about here] }
$$

Results in Panel A show that parameters are not significantly different across states, however the constant variance is still higher for the opaque portfolio compared to the transparent portfolio. In Panel B, the model having the credit component as an independent variable shows that the existence of only one regime can be rejected at the $90 \%$ confidence level. The impact of credit is significantly 
different across states and across portfolios: opaque firms are influenced by the level of credit to a greater degree than transparent firms.

The identification of high or low credit state is more challenging because we restrict variance to be constant across regimes. Nonetheless, Table 10 confirms that opaque portfolios are more sensitive to the underlying economic conditions and credit has a heterogeneous impact across states.

\subsection{An alternative credit variable}

We run a robustness check where credit residuals enter the regime switching model as an independent variable and where the time varying transition probability structure is driven by the Composite Leading Indicators (CLI). We choose to consider the index of Composite Leading Indicators as a driver of the state probabilities because it is widely regarded as a proxy for economic conditions. Table 11 reports the results. Contrarily to our original results, the parameter estimates are not significantly different across regimes when the Composite Leading Indicator drives the state probability. Consequently, having the credit cycle driving the transition probability equation leads to a more accurate investigation of our research question.

$$
\text { [Insert Table } 11 \text { about here] }
$$

\subsection{The inclusion of leverage}

As an additional robustness check we control for leverage. Leverage is in fact considered to be one of the factors influencing the accessibility by firms to external sources of credit. According to our hypothesis opacity is also a major determinant of access to capital. Because leverage is not one of the characteristics that necessarily increases opacity, it would be erroneous to include it in the computation of our opacity index; we account for firm's leverage level by including it as a control in our linear panel regressions similar to Equation 2 in Section 6. 
We compute leverage as the sum of long-term debt and debt in current liabilities over market value of equity. ${ }^{15}$ Judge and Korzhenitskaya (2012) find that firms constrained by poor access to credit are significantly under-levered; in our study these firms are opaque firms and, following our hypotheses, we should expect a negative effect of leverage on excess returns. On the other hand, it might also be that a higher leverage leads to higher returns because it indicates a higher risk exposure for the firm. Our results are in favor of the former, where leverage significantly negatively impacts the excess returns despite the model chosen for the analysis. Table 12 reports the results.

[Insert Table 12 about here]

The results are in line with our previous results: the opacity factor has a positive significant impact on excess returns, being in a period below the credit trend negatively affects returns but a further tightening of credit increases the excess returns. Model 6 also takes into account the financial constraint levels of firms, captured through the CMU factor (Constrained-Minus-Unconstrained) as the difference between returns of the most financially constrained and the least financially constrained according to the $10^{\text {th }}$ and the $90^{\text {th }}$ percentile breakpoints of the $\mathrm{KZ}$ index.

After accounting for market, size and value factors, a higher level of financial constraints negatively impacts the excess returns of firms. This result is in line with Lamont, Polk and SaaRequejo's (2001) findings. The effect of leverage is consistent throughout the models, having a negative and significant impact of about 3 basis points on firm's excess returns.

\footnotetext{
15 We run the same analysis using several different leverage ratios: long-term debt to book value of equity, long-term debt to market value of equity, debt to net working capital ratio, and financial debt to stockholder's equity. Results are robust when using long-term debt to market value of equity, in the other instances leverage has a negative but insignificant impact on excess returns.
} 


\section{Summary and Contribution}

This paper aimed at providing a deeper understanding of the effect of the credit cycle on opaque firms. We address two core macro-finance questions: what are the state of the nature and regimes in which excess returns are the highest? And, what macroeconomic state variables drive excess returns?

Results from a multivariate Markov regime-switching model and a portfolio linear analysis support our hypotheses that opaque firms are more sensitive to changes in credit conditions and that opacity subsumes both a size and financial constraint effect. Lastly, our results consider the effect of a shift in monetary policy on the financial sector and how this impacts different firms in the cross-section. We conclude that the credit cycle has a differential effect across firms having different opacity levels. 


\section{References}

Adrian, T., Shin, H. S., 2008. Liquidity and financial cycles, BIS Working Paper No. 256.

Baker, M., Stein, J., Wurgler, J., 2003, When does the market matter? Stock prices and the investment of equity-dependent firms. Quarterly Journal of Economics, 118, 969-1006.

Baker, M., and Wurgler, J., 2006. Investor sentiment and the cross-section of stock returns. Journal of Finance, 61, 1645-1680.

Berger, D., Turtle, H. J., 2012. Cross-sectional performance and investor sentiment in a multiple risk factor model. Journal of Banking and Finance, 36, 1107-1121.

Bernanke, B. S., 1983. Nonmonetary effects of the financial crisis in propagation of the great depression. American Economic Review, 73(3), 257-76.

Bernanke, B. S., Gertler, M., 1995. Inside the black box: the credit channel of monetary policy transmission. Journal of Economic Perspectives, 9(4): 27-48.

Bhattacharya, U., Daouk, H., Welker, M., 2003. The world price of earnings opacity. The Accounting Review, Vol. 78, No. 3: 641-678.

Borio, C., Furfine, C., and Lowe, P., 2001. Procyclicality of the financial system and financial stability: issues and policy options, BIS papers 1, 1-57.

Boissay, Frederic, Fabrice Collard, Frank Smets, 2013, Booms and Banking Crises. Unpublished working paper available at SSRN 2131075.

Bougheas, S., Mizen, P., Yalcin, C., 2006. Access to external finance: theory and evidence on the impact of monetary policy and firm-specific characteristics. Journal of Banking and Finance, 30, 199227.

Buncic, D., Melecky, M., 2013. Equilibrium credit: the reference point for macroprudential supervisors. World Bank Policy Research working paper, WPS 6358.

Chan, L., Lakonishok, J., Sougiannis, T., 2001. The stock market valuation of research and development expenditures. Journal of Finance, 56 (6), 2431-2456.

Davig, Tory, Craig Hakkio, 2010. What is the effect of financial stress on the economic activity? Federal Reserve Bank of Kansas City Economic Review, 95 (2), 35-62.

Dechow, P. M., Sloan, R. G., Sweeny, A. P., 1995. Detecting earnings management. The Accounting Review, 70 (2), 193-225.

Ding, Z., 2012. An implementationof Markov regime switching model with time varying transition probabilities in Matlab, Available at SSRN: http://ssrn.com/abstract=2083332 or http://dx.doi.org/10.2139/ssrn.2083332 
Fama, E., French, K., 1989. Business conditions and expected returns on stock and bonds. Journal of Financial Economics, 25, 23-49.

Fama, E., French, K., 1992. The cross section of expected stock returns. Journal of Finance, 47.

Fama, E., French, K., 1993. Common risk factors in the returns on stocks and bonds. Journal of Financial Economics, 33, 2-56.

Fama, E., French, K., 2006. Profitability, investment and average returns. Journal of Financial Economics, 82, 491-518.

Fazzari, S., Hubbard, R. G., Petersen, B., 1988. Financing constraints and corporate investments, Brookings Papers of Economic Activity, 141-195.

Gertler, M., 1988. Financial structure and aggregate economic activity: an overview. Journal of Money, Credit and Banking, 20(3), 559-88.

Gertler, M., Gilchrist, S., 1994. Monetary policy, business cycles, and the behavior of small manufacturing firms. Quarterly Journal of Economics, 109, 309-340.

Gertler, M., Hubbard, G., 1988. Financial factors in business fluctuations, NBER Working Paper No. 2758.

Gorton, G., He, P., 2005. Bank Credit Cycles, Unpublished Working Paper.

Gourinchas, P. O., Obstfeld, M., 2011. Stories of the twentieth century for the twenty-first. American Economic Journal: Macroeconomics, American Economic Association, 4 (1), 226-65.

Gray, S. F., 1996. Modeling the Conditional Distribution of Interest Rates as a Regime-Switching Process. Journal of Financial Economics, 42, 27-62.

Hamilton, J. D., 1989. A New Approach to the Economic Analysis of Nonstationary Time Series and the Business Cycle. Econometrica 57, 357-384.

Hamilton, J. D., 2017. Why You Should Never Use the Hodrick-Prescott Filter, Unpublished Working Paper, available from http://econweb.ucsd.edu/ jhamilto/hp.pdf.

Hatzius, J., Hooper, P., Mishkin, F., Schoenholtz, K., Watson, M., 2010. Financial Codition Indexes: a fresh look after the financial crisis, NBER working paper no. 16150.

Hirshleifer, D., Hou, K., Teoh, S. H., 2009. Accruals, cash flows, and aggregate stock returns. Journal of Financial Economics, 91, 389-406.

Hubrich, K., Tetlow, R., 2014. Financial stress and economic dynamics, the transmission of crises, NBER working paper no. 1728.

Hutton, A. P., Marcus, A. J., Tehranian, H., 2009. Opaque financial reports, R2, and crash risk. Journal of Financial Economics, 94, 67-86. 
Judge, A., Korzhenitskaya, A., 2012. Credit market conditions and the impact of access to the public debt market on corporate leverage. International Review of Financial Analysis, 25: 28-63.

Jones, Jennifer J., 1991, Earnings management during import relief investigations. Journal of Accounting Research, Vol. 29, No. 2, 193-228.

Kaplan, S., Zingales, L., 1997. Do financing constraints explain why investment is correlated with cash flow? Quarterly Journal of Economics, 112, 169-216.

Kashyap, A., Stein, J., Wilcox, D., 1993. Monetary policy and credit conditions: evidence from the composition of external finance. The American Economic Review, 83 (1), 78-98.

Kashyap, A., Lamont, O., Stein, J., 1994. Credit conditions and the cyclical behavior of inventories. Quarterly Journal of Economics, 109, 565-592.

Kiyotaki, N., Moore, J., 1997. Credit cycles. The Journal of Political Economy, 105 (2), 211-2448.

Lamont, O., Polk, C., Saa-Requejo, J., 2001. Financial constraints and stock returns. The Review of Financial Studies, 14 (2), 529-554.

Leary, M. T., 2009. Bank loan supply, lender choice, and corporate capital structure. Journal of Finance, 64, 1143-1185.

Li, D., 2011. Financial Constraints, R\&D Investment, and Stock Returns. The Review of Financial Studies, 24 (9), 2974-3007.

Livdan, D., Sapriza, H., Zhang, L., 2009. Financially constrained stock returns. Journal of Finance, 64 (4), 1827-1862.

Mendoza, E., Terrones, M., 2008. An Anatomy of Credit Booms and their Demise, NBER working paper no. 18379.

Morley, J., 2015. Macro-financial linkages. Journal of Economic Surveys, doi:10.1111/joes.12108.

Mishkin, F. S., 1978. The household balance sheet and the great depression. Journal of Economic History, 38, 918-37.

Perlin, M, 2015. MS_Regress - The MATLAB Package for Markov Regime Switching Models (April 19, 2015). Available at SSRN: $\underline{\text { http://ssrn.com/abstract }=1714016}$ or http://dx.doi.org/10.2139/ssrn.1714016

Perez-Quiros, G., Timmermann, A., 2000. Firm size and cyclical variations in stock returns. Journal of Finance, 55 (3), 1229-1262.

Pontiff, J., Schall, L. D., 1998. Book-to-market ratios as predictors of market returns. Journal of Financial Economics, 49, 141-160.

Pozsar, Z., Adrian, T., Ashcraft, A., Boesky, H., 2010. Shadow banking. Federal Reserve Bank of New York, Staff Report no. 458. 
Rey, H., 2013. Dilemma not Trilemma: The global financial cycle and monetary policy. Independence, Jackson Hole Symposium.

Sato, Y., 2013. Opacity in Financial Markets, Unpublished Working Paper. University of Lausanne.

Schularick, M., Taylor, A., 2009. Credit booms gone bust: monetary policy, leverage cycles and financial crises, 1870-2008, NBER Working Paper No. 15512.

Thorbecke, W., 1997. On stock market returns and monetary policy. Journal of Finance, 52(2), 635-54.

Whited, T., Wu, G., 2006. Financial constraints risk. Review of Financial Studies, 19 (2), 531-559. 


\section{Tables}

\section{Table 1. Summary Statistics}

This table presents summary statistics for our data from January 1973 through December 2015. Accounting and financial firm level variables are retrieved from Compustat and CRSP respectively. The size, value, momentum and market factor are retrieved from Kenneth French's data library.

\begin{tabular}{lrrrrr}
\hline Variable & Mean & Median & Std. Dev & Minimum & Maximum \\
\hline Credit Residuals & 0.004 & 0.016 & 0.088 & -0.170 & 0.139 \\
Credit (Billions \$) & $4,367.34$ & $3,191.04$ & $3,245.60$ & 610.84 & $11,674.40$ \\
R\&D exp./assets & 0.086 & 0.044 & 0.144 & 0.000 & 6.435 \\
Age & 19.140 & 15.00 & 13.555 & 2.000 & 83.000 \\
Size (log) & 12.356 & 12.222 & 2.143 & 5.457 & 20.389 \\
Total Current Assets (log) & 5.289 & 5.061 & 2.044 & -1.561 & 12.764 \\
Book-to-Market & 0.709 & 0.521 & 0.704 & 0.000 & 18.366 \\
Market Factor & 0.559 & 0.925 & 4.603 & -23.240 & 16.100 \\
Small-Minus-Big & 0.245 & 0.135 & 3.111 & -16.700 & 22.320 \\
High-Minus-Low & 0.329 & 0.290 & 2.992 & -13.110 & 13.910 \\
Momentum & 0.663 & 0.740 & 4.457 & -34.580 & 18.380 \\
\hline
\end{tabular}


Table 2. The Opacity Index

This table reports the computation of the yearly opacity index. On June of every year we run a principal component analysis in order to construct and compute the yearly opacity index for each firm. The index is constructed as a linear combination of the first principal component of the following variables: property plant and equipment over total assets (Tangibility), log of Age, log of Size (price times shares outstanding), book-to-market (BEME), R\&D expenditures over total assets $(R \& D)$, and discretionary current accruals (DCAJones) computed as in Jones (1991).

\begin{tabular}{|c|c|c|c|c|c|c|}
\hline Year & Tangibility & Age & Size & BEME & R\&D & DCA Jones \\
\hline 1973 & -0.112790 & -0.436550 & -0.646303 & 0.473915 & -0.334130 & -0.206777 \\
\hline 1974 & -0.525156 & -0.553987 & -0.570711 & 0.163472 & 0.186446 & 0.173532 \\
\hline 1975 & -0.475237 & -0.527419 & -0.607401 & 0.309919 & 0.163769 & -0.064600 \\
\hline 1976 & -0.486098 & -0.566932 & -0.566348 & 0.139951 & 0.246330 & -0.203180 \\
\hline 1977 & -0.467503 & -0.544755 & -0.572128 & 0.117235 & 0.289438 & 0.244611 \\
\hline 1978 & -0.492461 & -0.556874 & -0.468431 & -0.148236 & 0.363185 & 0.272158 \\
\hline 1979 & -0.485429 & -0.510421 & -0.393225 & -0.273288 & 0.392847 & 0.346682 \\
\hline 1980 & -0.460935 & -0.516472 & -0.311185 & -0.365233 & 0.408902 & 0.351232 \\
\hline 1981 & -0.483342 & -0.536064 & -0.314240 & -0.376388 & 0.395531 & 0.286628 \\
\hline 1982 & -0.496712 & -0.557806 & -0.376569 & -0.373665 & 0.385958 & 0.108333 \\
\hline 1983 & -0.423402 & -0.530842 & -0.297125 & -0.413908 & 0.392055 & 0.354439 \\
\hline 1984 & -0.490079 & -0.537669 & -0.356193 & -0.409374 & 0.360331 & 0.215492 \\
\hline 1985 & -0.488802 & -0.570589 & -0.415714 & -0.294704 & 0.403743 & -0.113246 \\
\hline 1986 & -0.489149 & -0.582293 & -0.414804 & -0.296029 & 0.396079 & -0.071372 \\
\hline 1987 & -0.464629 & -0.610522 & -0.496462 & -0.118464 & 0.385068 & -0.050968 \\
\hline 1988 & -0.479192 & -0.604537 & -0.493058 & -0.029703 & 0.397295 & 0.055491 \\
\hline 1989 & -0.488662 & -0.599969 & -0.470618 & -0.111605 & 0.407730 & 0.081801 \\
\hline 1990 & -0.478989 & -0.611544 & -0.481169 & -0.043986 & 0.402160 & -0.037309 \\
\hline 1991 & -0.450818 & -0.593698 & -0.527009 & 0.124953 & 0.364342 & -0.164867 \\
\hline 1992 & -0.500775 & -0.608378 & -0.443482 & -0.023493 & 0.415565 & -0.095804 \\
\hline 1993 & -0.506988 & -0.601522 & -0.353451 & -0.120163 & 0.466462 & -0.155504 \\
\hline 1994 & -0.494293 & -0.595884 & -0.416998 & -0.095835 & 0.419538 & -0.203746 \\
\hline 1995 & -0.504736 & -0.617014 & -0.439234 & -0.046874 & 0.411417 & 0.012108 \\
\hline 1996 & -0.507884 & -0.612220 & -0.283443 & -0.239275 & 0.474087 & -0.069927 \\
\hline 1997 & -0.512925 & -0.605929 & -0.406702 & -0.086575 & 0.437744 & -0.072364 \\
\hline 1998 & -0.491201 & -0.603701 & -0.444449 & 0.008019 & 0.433558 & -0.093250 \\
\hline 1999 & -0.458612 & -0.602550 & -0.482097 & 0.097137 & 0.423464 & -0.073718 \\
\hline
\end{tabular}


Table 2, continued

\begin{tabular}{lrrrrrr}
\hline Year & Tangibility & Age & Size & BEME & R\&D & DCA Jones \\
\hline 2000 & -0.490090 & -0.515785 & -0.138514 & -0.498211 & 0.458672 & -0.126479 \\
2001 & -0.426644 & -0.576408 & -0.408148 & 0.200368 & 0.380475 & -0.366381 \\
2002 & -0.420234 & -0.587366 & -0.439138 & 0.014415 & 0.496845 & -0.196214 \\
2003 & -0.319537 & -0.556540 & -0.528339 & 0.351510 & 0.389154 & -0.184436 \\
2004 & -0.450264 & -0.582828 & -0.258627 & -0.311167 & 0.541835 & -0.016603 \\
2005 & -0.437678 & -0.589263 & -0.345131 & -0.205771 & 0.524925 & -0.155579 \\
2006 & -0.400116 & -0.598705 & -0.366576 & -0.199877 & 0.548638 & -0.078276 \\
2007 & -0.398513 & -0.588147 & -0.407452 & -0.149045 & 0.550861 & 0.059925 \\
2008 & -0.292686 & -0.580155 & -0.586226 & 0.219847 & 0.392214 & -0.178686 \\
2009 & -0.284484 & -0.582257 & -0.560563 & 0.236493 & 0.452019 & 0.074596 \\
2010 & -0.318580 & -0.618518 & -0.483594 & 0.008282 & 0.531006 & 0.006586 \\
2011 & -0.354951 & -0.554374 & -0.373296 & -0.148696 & 0.571272 & 0.280835 \\
2012 & -0.124074 & -0.565399 & -0.613512 & 0.249831 & 0.472533 & 0.053197 \\
2013 & -0.215728 & -0.564480 & -0.500554 & 0.138970 & 0.513178 & -0.318755 \\
2014 & -0.297191 & -0.570578 & -0.476665 & 0.070683 & 0.501811 & 0.319528 \\
2015 & -0.244311 & -0.596819 & -0.534177 & 0.140075 & 0.527413 & 0.031435 \\
\hline Average & -0.423067 & -0.572646 & -0.437024 & -0.053825 & 0.403297 & 0.000711 \\
\hline
\end{tabular}




\section{Table 3. Summary Statistics of Opaque Portfolios}

This table presents summary statistics for quantile portfolios constructed on the opacity index. Portfolios are formed by ranking all available NYSE-AMEX-NASDAQ firms by the opacity index in each June of year $t$ from 1973 to 2015. Portfolio construction follows Fama and French (1992) procedure.

Panel A reports the summary statistics of firm characteristics by opacity level. MarketCap is price times shares outstanding, TotalAssets is firm's current total assets, Age is the current age of the firm calculated since its first appearance on Compustat, BEME is book-to-market, PPE/Assets captures the tangibility of a firm, $R \& D /$ Assets is measured as research and development expenses over total assets and it captures the tangibility of a firm, Earnings Management is the three-year moving sum of discretionary accruals computed according to Hutton, Marcus and Tehranian (2009). The Opacity Index is the linear combination of first principal component derived from the following firm-level variables: property plant and equipment over total assets, log of age, log of size (shares outstanding times price), book-to-market, discretionary current accruals computed as in Jones (1991). Portfolio 1 contains the most transparent firms, while portfolio 5 the most opaque firms. A larger index value corresponds to higher opacity. The difference in means between portfolio 1 and 5 is tested trough a t-test, while the difference in median is tested according to median score analysis. Panels B and $\mathrm{C}$ report the average returns for annually rebalanced equal-weighted quintile and decile opaque portfolios. There are 510 time series observations for each opaque portfolios.

\begin{tabular}{|c|c|c|c|c|c|c|c|c|}
\hline \multicolumn{9}{|c|}{ Panel A: Summary statistics of firm characteristics by opaque portfolio } \\
\hline Variable & & 1 (Low) & 2 & 3 & 4 & 5 (High) & $1-5$ & All \\
\hline Opacity & Mean & -8.852 & -7.610 & -6.892 & -6.307 & -5.517 & $(0.01)^{* * *}$ & $(0.01)^{* * *}$ \\
\hline Index & Median & -9.021 & -7.714 & -6.974 & -6.389 & -5.666 & $(0.01)^{* * *}$ & $(0.01)^{* * *}$ \\
\hline \multirow[t]{2}{*}{ MarketCap(log) } & Mean & 15.007 & 13.148 & 12.117 & 11.301 & 10.559 & $(0.01)^{* * *}$ & $(0.01)^{* * *}$ \\
\hline & Median & 14.900 & 13.099 & 12.108 & 11.283 & 10.416 & $(0.01)^{* * *}$ & $(0.01)^{* * *}$ \\
\hline \multirow[t]{2}{*}{ TotalAsssets(log) } & Mean & 7.983 & 6.087 & 5.004 & 4.188 & 3.532 & $(0.01)^{* * *}$ & $(0.01)^{* * *}$ \\
\hline & Median & 7.901 & 6.002 & 4.893 & 4.109 & 3.360 & $(0.01)^{* * *}$ & $(0.01)^{* * *}$ \\
\hline \multirow[t]{2}{*}{ Age (log) } & Mean & 3.493 & 2.962 & 2.616 & 2.365 & 2.146 & $(0.01)^{* * *}$ & $(0.01)^{* * *}$ \\
\hline & Median & 3.555 & 3.045 & 2.639 & 2.398 & 2.079 & $(0.01)^{* * *}$ & $(0.01)^{* * *}$ \\
\hline \multirow[t]{2}{*}{$B E M E$} & Mean & 0.579 & 0.653 & 0.688 & 0.732 & 0.881 & $(0.01)^{* * *}$ & $(0.01)^{* * *}$ \\
\hline & Median & 0.452 & 0.561 & 0.534 & 0.551 & 0.579 & $(0.01)^{* * *}$ & $(0.01)^{* * *}$ \\
\hline \multirow[t]{2}{*}{ PPE/Assets } & Mean & 0.603 & 0.518 & 0.439 & 0.384 & 0.358 & $(0.01)^{* * *}$ & $(0.01)^{* * *}$ \\
\hline & Median & 0.569 & 0.474 & 0.397 & 0.343 & 0.300 & $(0.01)^{* * *}$ & $(0.01)^{* * *}$ \\
\hline \multirow[t]{2}{*}{$R \& D / A s s e t s$} & Mean & 0.040 & 0.052 & 0.071 & 0.098 & 0.154 & $(0.01)^{* * *}$ & $(0.01)^{* * *}$ \\
\hline & Median & 0.026 & 0.031 & 0.045 & 0.060 & 0.086 & $(0.01)^{* * *}$ & $(0.01)^{* * *}$ \\
\hline Earnings & Mean & -0.015 & -0.012 & -0.008 & -0.011 & -0.018 & $(0.01)^{* * *}$ & $(0.01)^{* * *}$ \\
\hline Management & Median & -0.011 & -0.009 & -0.008 & -0.011 & -0.013 & $(0.01)^{* * *}$ & $(0.01)^{* * *}$ \\
\hline Average Obs & & 203 & 202 & 202 & 201 & 244 & & \\
\hline
\end{tabular}


Table 3, continued

\begin{tabular}{|c|c|c|c|c|}
\hline \multicolumn{5}{|c|}{ Panel B: Equal Weighted Returns of Opaque Quintile Portfolios } \\
\hline Portfolio & Mean & Std Dev & Minimum & Maximum \\
\hline Low Opacity & 0.878 & 5.214 & -26.582 & 19.217 \\
\hline 2 & 1.065 & 6.102 & -31.196 & 23.571 \\
\hline 3 & 1.189 & 7.033 & -32.786 & 29.707 \\
\hline 4 & 1.329 & 7.632 & -32.732 & 33.049 \\
\hline High Opacity & 2.348 & 8.545 & -29.452 & 48.912 \\
\hline \multicolumn{5}{|c|}{ Panel C: Equal Weighted Returns of Opaque Deciles Portfolios } \\
\hline Portfolio & Mean & Std Dev & Minimum & Maximum \\
\hline Low Opacity & 0.780 & 4.847 & -23.808 & 21.467 \\
\hline 2 & 0.976 & 5.755 & -29.355 & 24.562 \\
\hline 3 & 1.051 & 5.972 & -30.198 & 23.813 \\
\hline 4 & 1.080 & 6.337 & -32.218 & 23.300 \\
\hline 5 & 1.133 & 6.919 & -32.688 & 26.744 \\
\hline 6 & 1.244 & 7.276 & -32.881 & 33.080 \\
\hline 7 & 1.332 & 7.559 & -31.315 & 35.390 \\
\hline 8 & 1.327 & 7.887 & -34.149 & 33.887 \\
\hline 9 & 1.797 & 8.408 & -30.545 & 40.081 \\
\hline High Opacity & 2.736 & 8.866 & -28.691 & 55.572 \\
\hline
\end{tabular}


Table 4. Equal weighted returns for size and financially constrained portfolios

Equal weighted returns for size and financially constrained portfolios.

Average returns for annually rebalanced equal-weighted size portfolios are formed by ranking all available NYSE-AMEX-NASDAQ firms by size or financial constraint index in each June of year $t$ from 1973 to 2015. Portfolio construction follows Fama and French (1992) procedure. Panel A reports the two portfolios constructed on the median size; Panel B reports the quintile size portfolios; Panel C and D report portfolios constructed respectively on the median Whited-Wu and Kaplan-Zingales financial constraint indices. There are 510 observations for each size portfolios.

\begin{tabular}{|c|c|c|c|c|}
\hline \multicolumn{5}{|c|}{ Panel A: Equal Weighted Returns of Size Median Portfolios } \\
\hline Portfolio & Mean & Std Dev & Minimum & Maximum \\
\hline Small & 1.781 & 7.448 & -31.097 & 37.577 \\
\hline Big & 0.919 & 6.178 & -29.906 & 20.892 \\
\hline \multicolumn{5}{|c|}{ Panel B: Equal Weighted Returns of Size Quintile Portfolios } \\
\hline Portfolio & Mean & Std Dev & Minimum & Maximum \\
\hline Small & 2.374 & 7.749 & -29.106 & 42.444 \\
\hline 2 & 1.505 & 7.655 & -31.325 & 36.759 \\
\hline 3 & 1.093 & 7.268 & -33.818 & 28.186 \\
\hline 4 & 0.994 & 6.643 & -31.719 & 22.695 \\
\hline Large & 0.797 & 5.551 & -26.673 & 18.785 \\
\hline
\end{tabular}

\begin{tabular}{lcccc}
\multicolumn{4}{l}{ Panel C: Equal Weighted Returns of Financially Constrained } & \multicolumn{3}{l}{ Median Portfolios - WW Index } \\
\hline Porffolio & Mean & Std Dev & Minimum & Maximum \\
\hline Unconstrained & 1.014 & 5.534 & -28.357 & 20.534 \\
Constrained & 1.467 & 7.129 & -31.233 & 31.590 \\
\hline Panel D: Equal Weighted Returns of Financially Constrained & Median Portfolios & - KZ Index \\
\hline Portfolio & Mean & Std Dev & Minimum & Maximum \\
\hline Unconstrained & 1.217 & 6.602 & -29.471 & 31.268 \\
Constrained & 1.505 & 6.592 & -31.545 & 29.894 \\
\hline
\end{tabular}




\section{Table 5. Equal weighted returns for portfolios formed on opacity and size}

Average returns for annually rebalanced equal-weighted portfolios reported in Panel A (Panel B) are the intersection of two portfolios formed on size (the financial constraint $\mathrm{KZ}$ index) and three portfolios formed on the opacity index. Portfolio construction follows Fama and French (1992) procedure. The size breakpoint for year $t$ is the $50^{\text {th }}$ percentile size at the end of June $\mathrm{t}-1$. The $\mathrm{KZ}$ index breakpoint for year $\mathrm{t}$ is the NYSE-AMEX-NASDAQ $50^{\text {th }}$ percentile at the end of June $\mathrm{t}-1$. The opacity index breakpoint for year $t$ is the NYSE-AMEX-NASDAQ $30^{\text {th }}$ and $70^{\text {th }}$ percentile and median at the end of June $\mathrm{t}-1$. There are 510 observations for each formed portfolio.

Panel A: Equal Weighted Returns of portfolios formed on opacity $30^{\text {th }}$ and $70^{\text {th }}$ percentiles and on size median.

\begin{tabular}{lcccc}
\hline Portfolio & Mean & Std Dev & Minimum & Maximum \\
\hline Small & & & & \\
1 Opaque & 2.071 & 8.275 & -30.822 & 43.873 \\
2 Neutral & 1.318 & 6.825 & -31.532 & 34.147 \\
$\quad$ 3 Transparent & 1.247 & 7.946 & -32.743 & 40.834 \\
Big & & & & \\
$\quad$ 4 Opaque & 1.797 & 8.862 & -30.777 & 38.989 \\
5 Neutral & 0.968 & 7.171 & -33.021 & 30.105 \\
6 Transparent & 0.879 & 5.349 & -27.768 & 20.736 \\
\hline
\end{tabular}

Panel B: Equal Weighted Returns of portfolios formed on opacity $30^{\text {th }}$ and $70^{\text {th }}$ percentiles and on KZ index median.

\begin{tabular}{lcccr}
\hline Porffolio & Mean & Std Dev & Minimum & Maximum \\
\hline Unconstrained & & & & \\
1 Opaque & 1.729 & 8.092 & -31.358 & 41.858 \\
2 Neutral & 1.054 & 7.010 & -30.307 & 36.892 \\
3 Transparent & 0.821 & 5.358 & -26.628 & 18.932 \\
Constrained & & & & \\
4 Opaque & 2.249 & 8.314 & -30.416 & 45.175 \\
5 Neutral & 1.250 & 6.948 & -34.630 & 28.713 \\
6 Transparent & 0.992 & 5.604 & -29.012 & 23.150 \\
\hline
\end{tabular}




\section{Table 6}

The credit cycle and excess returns.

This table reports standardize parameter estimates and statistical significance for six variations of the following panel OLS model:

$$
r_{\mathrm{i}, \mathrm{t}}=\beta_{0}+\beta_{1} M K T_{\mathrm{t}}+\beta_{2} S M B_{\mathrm{t}}+\beta_{3} H M L_{\mathrm{t}}+\beta_{4} O M T_{\mathrm{t}}+\beta_{5} \text { Dummy }_{\mathrm{t}}+\beta_{6} \text { CreditGrowth }_{\mathrm{t}-1}+\varepsilon_{i t}
$$

where monthly excess returns, $r_{i t}$, are calculated as the difference between firms monthly returns and the one-month Treasury Bill rate. MKT is the excess return on the market; SMB captures the size effect; HML captures the value effect. The market, size, and value factors are retrieved from the Kenneth French library. The OMT (Opaque-Minus-Transparent) factor is computed as the difference between returns of opaque and transparent portfolios. The opacity breakpoint was the $10^{\text {th }}$ and $90^{\text {th }}$ percentile of the opacity index at the end of June t-1. Dummy captures periods of low credit and it equals 1 in periods of credit level below the trend, and 0 otherwise; CreditGrowth is the growth in credit residuals from regressing the natural logarithm of total bank credit of all commercial banks on a time trend.

\begin{tabular}{|c|c|c|c|c|c|c|}
\hline Variable & Model 1 & Model 2 & Model 3 & Model 4 & Model 5 & Model 6 \\
\hline MKT & $\begin{array}{r}0.295^{* * *} \\
(0.00)\end{array}$ & $\begin{array}{r}0.293^{* * *} * \\
(0.00)\end{array}$ & $\begin{array}{r}0.293^{* * *} \\
(0.00)\end{array}$ & $\begin{array}{r}0.295^{* * *} \\
(0.00)\end{array}$ & $\begin{array}{r}0.295^{* * *} \\
(0.00)\end{array}$ & $\begin{array}{r}0.295^{* * *} \\
(0.00)\end{array}$ \\
\hline SMB & $\begin{array}{r}0.117 * * * \\
(0.00)\end{array}$ & $\begin{array}{r}0.176^{* * *} * \\
(0.00)\end{array}$ & $\begin{array}{r}0.176^{* * *} \\
(0.00)\end{array}$ & $\begin{array}{r}0.119 * * * \\
(0.00)\end{array}$ & $\begin{array}{r}0.118^{* * *} \\
(0.00)\end{array}$ & $\begin{array}{r}0.119^{* * *} \\
(0.00)\end{array}$ \\
\hline HML & $\begin{array}{r}0.012 * * * \\
(0.00)\end{array}$ & $\begin{array}{r}-0.002 \\
(0.41)\end{array}$ & $\begin{array}{r}-0.002 \\
(0.34)\end{array}$ & $\begin{array}{r}0.012^{* * *} \\
(0.00)\end{array}$ & $\begin{array}{r}0.012^{* * *} \\
(0.00)\end{array}$ & $\begin{array}{r}0.012^{* * *} \\
(0.00)\end{array}$ \\
\hline OMT & $\begin{array}{r}0.086^{* * * *} \\
(0.00)\end{array}$ & & & $\begin{array}{r}0.085^{* * *} \\
(0.00)\end{array}$ & $\begin{array}{r}0.086^{* * *} \\
(0.00)\end{array}$ & $\begin{array}{r}0.085^{* * *} \\
(0.00)\end{array}$ \\
\hline Dummyt & & $\begin{array}{r}-0.016 \text { *** } \\
(0.00)\end{array}$ & & $\begin{array}{r}-0.011 * * * \\
(0.00)\end{array}$ & & $\begin{array}{r}-0.012^{* * *} \\
(0.00)\end{array}$ \\
\hline CreditGrowth $_{\mathrm{t}-1}$ & & & $\begin{array}{r}-0.006^{* * *} \\
(0.00) \\
\end{array}$ & & $\begin{array}{r}-0.003 * * \\
(0.05) \\
\end{array}$ & $\begin{array}{r}-0.002^{* *} \\
(0.05) \\
\end{array}$ \\
\hline Intercept & Yes*** & Yes*** & Yes*** & Yes*** & Yes*** & Yes*** \\
\hline R-Squared & 0.15 & 0.14 & 0.14 & 0.15 & 0.15 & 0.15 \\
\hline
\end{tabular}

${ }^{* * *}$ indicates significance at the $1 \%$ level. ${ }^{* *}$ indicates significance at the $5 \%$ level. ${ }^{*}$ indicates significance at the $10 \%$ level. P-values are in parenthesis. 


\section{Table 7}

Credit growth and excess returns across opaque portfolios.

This table reports standardized parameter estimates and statistical significance for three OLS models regressed across the excess returns, $r_{t}$, of five opaque portfolios. Excess returns are measured as the difference between portfolio return and the one-month Treasury Bill rate. Portfolios are constructed by ranking firms on the level of opacity and assigning each firm to one of the five quintiles. Portfolios are rebalanced annually in June. CreditGrowth is the growth in credit residuals from regressing the natural logarithm of total bank credit of all commercial banks on a time trend. $M K T$ is the excess return on the market and is retrieved from the Kenneth French library; HML is the average return on the two value portfolios minus the average return on the two growth portfolios.

\section{Panel A}

Panel A reports the standardized parameter estimates for the following OLS model across opaque portfolio quintiles:

$$
r_{t}^{i}=\beta_{0}^{i}+\beta_{1}^{i} \text { CreditGrowth } t-1_{2}+\beta_{2}^{i} M K T_{\mathrm{t}}+\beta_{3}^{i} S M B_{\mathrm{t}}+\beta_{4}^{i} H M L_{t}+\varepsilon_{t}^{i} \quad \text { for } \mathrm{i}=\{1,2,3,4,5\} .
$$

\begin{tabular}{|c|c|c|c|c|c|}
\hline \multicolumn{6}{|c|}{ Opaque Portfolios } \\
\hline Variable & 1 (Low) & 2 & 3 & 4 & 5 (High) \\
\hline \multirow{2}{*}{ CreditGrowth } & $-0.002 * * *$ & $-0.006^{* * *}$ & $-0.007 * * *$ & $-0.018^{* * *}$ & $-0.030^{* * *}$ \\
\hline & $(0.00)$ & $(0.00)$ & $(0.00)$ & $(0.00)$ & $(0.00)$ \\
\hline \multirow[t]{2}{*}{ MKT } & $0.945^{* * *}$ & $0.818^{* * *}$ & $0.710 * * *$ & $0.669 * * *$ & $0.557 * * *$ \\
\hline & $(0.00)$ & $(0.00)$ & $(0.00)$ & $(0.00)$ & $(0.00)$ \\
\hline \multirow[t]{2}{*}{ SMB } & $0.084 * * *$ & $0.371 * * *$ & $0.487 * * *$ & $0.502 * * *$ & $0.535^{* * *}$ \\
\hline & $(0.00)$ & $(0.00)$ & $(0.00)$ & $(0.00)$ & $(0.00)$ \\
\hline \multirow[t]{2}{*}{ HML } & $0.092 * * *$ & $0.059 * * *$ & $-0.005^{* * *}$ & $-0.037 * * *$ & $-0.062 * * *$ \\
\hline & $(0.00)$ & $(0.00)$ & $(0.00)$ & $(0.00)$ & $(0.00)$ \\
\hline Intercept & Yes*** & Yes*** & Yes*** & Yes*** & Yes*** \\
\hline R-Squared & 0.89 & 0.92 & 0.92 & 0.89 & 0.78 \\
\hline
\end{tabular}

Panel B reports the standardized parameter estimates for the following OLS model across opaque portfolio quintiles, where $\mathrm{i}=\{1,2,3,4,5\}$ :

$$
\begin{gathered}
r_{\mathrm{t}}^{i}=\beta_{0}^{i}+\beta_{1}^{i} \text { Dummy }_{t}+\beta_{2}^{i} \text { CreditGrowth }_{t}+\beta_{3}^{i} \text { Dummy }_{t} * \text { CreditGrowth }_{t}+\beta_{4}^{i} M K T_{t-1}+\beta_{5}^{i} S M B_{\mathrm{t}}+\beta_{6}^{i} H M L_{\mathrm{t}} \\
+\varepsilon_{t}^{i}
\end{gathered}
$$

\begin{tabular}{|c|c|c|c|c|c|}
\hline \multicolumn{6}{|c|}{ Opaque Portfolios } \\
\hline Variable & 1 (Low) & 2 & 3 & 4 & 5 (High) \\
\hline \multirow[t]{2}{*}{ Dummyt } & $-0.022 * * *$ & $-0.022 * * *$ & $-0.035^{* * *}$ & $-0.040 * * *$ & $-0.048^{* * *}$ \\
\hline & $(0.00)$ & $(0.00)$ & $(0.00)$ & $(0.00)$ & $(0.00)$ \\
\hline \multirow[t]{2}{*}{ CreditGrowth $_{t}$} & $0.041 * * *$ & $0.040 * * *$ & $0.088^{* * *}$ & $0.090 * * *$ & $0.082 * * *$ \\
\hline & $(0.00)$ & $(0.00)$ & $(0.00)$ & $(0.00)$ & $(0.00)$ \\
\hline \multirow{2}{*}{ Dummyt $^{*}$ CreditGrowth $_{t}$} & $-0.026 * * *$ & $-0.023 * * *$ & $-0.060 * * *$ & $-0.081 * * *$ & $-0.085 * * *$ \\
\hline & $(0.00)$ & $(0.00)$ & $(0.00)$ & $(0.00)$ & $(0.00)$ \\
\hline \multirow[t]{2}{*}{$\mathrm{MKT}$} & $0.943^{* * *}$ & $0.817 * * *$ & $0.707 * * *$ & $0.664 * * *$ & $0.552 * * *$ \\
\hline & $(0.00)$ & $(0.00)$ & $(0.00)$ & $(0.00)$ & $(0.00)$ \\
\hline \multirow[t]{2}{*}{ SMB } & $0.091 * * *$ & $0.371 * * *$ & $0.487 * * *$ & $0.500 * * *$ & $0.532 * * *$ \\
\hline & $(0.00)$ & $(0.00)$ & $(0.00)$ & $(0.00)$ & $(0.00)$ \\
\hline \multirow[t]{2}{*}{ HML } & $0.084 * * *$ & $0.058 * * *$ & $-0.008 * * *$ & $-0.040 * * *$ & $-0.065^{* * *}$ \\
\hline & $(0.00)$ & $(0.00)$ & $(0.00)$ & $(0.00)$ & $(0.00)$ \\
\hline Intercept & Yes*** & Yes*** & Yes*** & Yes*** & Yes*** \\
\hline R-Squared & 0.89 & 0.92 & 0.92 & 0.90 & 0.79 \\
\hline
\end{tabular}


Table 7, continued

$$
\text { Panel C }
$$

Panel $\mathrm{C}$ reports the standardized parameter estimates for the following OLS model across opaque portfolio quintiles, where $\mathrm{i}=\{1,2,3,4,5\}$ :

$$
r_{\mathrm{t}}^{i}=\beta_{0}^{i}+\beta_{1}^{i} \text { Dummy }_{t}+\beta_{2}^{i} \text { CreditGrowth }_{t}+\beta_{3}^{i} \text { Dummy }_{t} * \text { CreditGrowth }_{t}+\beta_{4}^{i} M K T_{t-1}+\beta_{5}^{i} H_{M} L_{\mathrm{t}}+\varepsilon_{t}^{i}
$$

\begin{tabular}{|c|c|c|c|c|c|}
\hline \multicolumn{6}{|c|}{ Opaque Portfolios } \\
\hline Variable & 1 (Low) & 2 & 3 & 4 & 5 (High) \\
\hline \multirow[t]{2}{*}{ Dummyt $_{t}$} & $-0.019 * * *$ & $-0.003 * * *$ & $-0.009 * * *$ & $-0.014 * * *$ & $-0.025^{* * *}$ \\
\hline & $(0.00)$ & $(0.00)$ & $(0.00)$ & $(0.00)$ & $(0.00)$ \\
\hline \multirow[t]{2}{*}{ CreditGrowth $_{\mathrm{t}}$} & $0.047 * * *$ & $0.069 * * *$ & $0.126^{* * *}$ & $0.129 * * *$ & $0.117 * * *$ \\
\hline & $(0.00)$ & $(0.00)$ & $(0.00)$ & $(0.00)$ & $(0.00)$ \\
\hline \multirow[t]{2}{*}{ Dummy $_{t} *$ CreditGrowth } & $-0.035^{* * *}$ & $-0.064 * * *$ & $-0.114 * * *$ & $-0.136 * * *$ & $-0.139 * * *$ \\
\hline & $(0.00)$ & $(0.00)$ & $(0.00)$ & $(0.00)$ & $(0.00)$ \\
\hline \multirow[t]{2}{*}{$\mathrm{MKT}$} & $0.959 * * *$ & $0.886^{* * *}$ & $0.797 * * *$ & $0.757 * * *$ & $0.651 * * *$ \\
\hline & $(0.00)$ & $(0.00)$ & $(0.00)$ & $(0.00)$ & $(0.00)$ \\
\hline \multirow[t]{2}{*}{ HML } & $0.074 * * *$ & $-0.015^{* * *}$ & $-0.105^{* * *}$ & $-0.139 * * *$ & $-0.174 * * *$ \\
\hline & $(0.00)$ & $(0.00)$ & $(0.00)$ & $(0.00)$ & $(0.00)$ \\
\hline Intercept & Yes*** & Yes*** & Yes*** & $\mathrm{Yes}^{* * *}$ & Yes*** \\
\hline R-Squared & 0.89 & 0.80 & 0.71 & 0.68 & 0.54 \\
\hline
\end{tabular}

${ }^{* * *}$ indicates significance at the $1 \%$ level. ${ }^{* *}$ indicates significance at the $5 \%$ level. P-values are in parenthesis. 


\section{Table 8}

Multivariate Markov Switching Model.

The table reports results for the multivariate Markov Switching Model A estimated across opaque portfolio quintiles. Opacity is captured as the linear combination of the first principal component derived from the following firm-level variables: property plant and equipment over total assets, log of age, log of size (shares outstanding times price), book-tomarket, discretionary current accruals computed as in Jones (1991).

The table reports the results for the following model with time varying transition probability:

$$
\begin{gathered}
r_{i, t}=\beta_{0 i, s t}+\beta_{1 i, s t}(1 \text { moTBill })_{t-1}+\beta_{2 i, s t}(\text { Def })_{t-1}+\beta_{3 i}\left(\text { DivYield }_{t-1}+\varepsilon_{i t}\right. \\
p_{i t}=\mathrm{P}\left(S_{i, t}=1 \mid S_{i, t-1}=1, Y_{t-1}\right)=\phi\left[\prod_{0 i, s t}+\prod_{1 i}\left(\text { CreditResid }_{t-1}\right)\right] \\
q_{i t}=\left(S_{i, t}=2 \mid S_{i, t-1}=2, Y_{t-1}\right)=\phi\left[\prod_{2 i, s t}+\prod_{3 i}\left(\text { CreditResid }_{t-1}\right)\right], i=\left\{\begin{array}{ll}
1 \text { to } 5
\end{array}\right\}
\end{gathered}
$$

where $\varepsilon_{\mathrm{t}}^{\mathrm{i}} \sim \mathrm{N}\left(0, \sigma_{\mathrm{i} 0, \mathrm{st}}^{2}\right), \mathrm{S}_{\mathrm{t}}=\{1,2\}$ and $\phi$ is the cumulative density function under the normality assumption. The

\begin{tabular}{|c|c|c|c|c|c|c|}
\hline \multicolumn{7}{|c|}{ Opaque Portfolios } \\
\hline & Parameters & 1 (Low) & 2 & 3 & 4 & 5 (High) \\
\hline \multicolumn{7}{|c|}{ Mean parameters } \\
\hline \multirow[t]{3}{*}{ State 1} & Constant & $2.177(1.35)$ & $3.164(2.29)$ & $3.772(2.90)$ & $4.352(3.34)$ & $6.353(2.96)$ \\
\hline & $1 \mathrm{mo}$ T-Bill rate & $-1.239(2.41)$ & $-1.619(3.95)$ & $-1.641(4.73)$ & $-1.794(5.24)$ & $-2.942(4.84)$ \\
\hline & Default & $1.949(1.15)$ & $1.931(1.88)$ & $2.003(2.55)$ & $1.971(2.66)$ & $2.583(2.00)$ \\
\hline \multirow[t]{3}{*}{ State 2} & Constant & $-2.209(2.30)$ & $-3.399(4.14)$ & $-4.415(3.72)$ & $-5.447(4.82)$ & $-5.705(3.27)$ \\
\hline & 1mo T-Bill rate & $1.108(3.49)$ & $1.427(6.51)$ & $1.495(6.06)$ & $1.614(6.55)$ & $2.553(4.85)$ \\
\hline & Default & $-1.486(2.12)$ & $-1.356(4.09)$ & $-1.102(3.65)$ & $-0.467(4.34)$ & $0.945(2.36)$ \\
\hline States 1,2 & Dividend Yield & $-0.020(0.47)$ & $0.017(0.96)$ & $0.010(1.17)$ & $0.011(1.12)$ & $-0.356(1.04)$ \\
\hline \multicolumn{7}{|c|}{ Variance parameters } \\
\hline State 1 & & $12.783(1.41)$ & $14.373(2.46)$ & $21.072(4.25)$ & $26.499(5.16)$ & $41.778(4.90)$ \\
\hline State 2 & & $15.565(3.13)$ & $19.642(7.62)$ & $22.518(9.65)$ & $25.924(8.17)$ & $33.733(8.18)$ \\
\hline \multicolumn{7}{|c|}{ Transition Prob. parameters } \\
\hline \multirow[t]{2}{*}{ State 1} & Constant & & & $0.398(0.09)$ & & \\
\hline & Credit & & & $1.154(1.01)$ & & \\
\hline \multirow[t]{2}{*}{ State 2} & Constant & & & $-0.040(0.11)$ & & \\
\hline & Credit & & & $-0.445(1.14)$ & & \\
\hline \multicolumn{2}{|c|}{ Log likelihood value } & & & $-7,831.40$ & & \\
\hline \multicolumn{2}{|l|}{$\mathrm{AIC} / \mathrm{BIC}$} & & & $15,7661 / 16,047$ & & \\
\hline \multicolumn{7}{|c|}{ Duration of Regimes } \\
\hline \multicolumn{2}{|l|}{ State 1} & & & 2.90 months & & \\
\hline \multicolumn{2}{|l|}{ State 2} & & & 2.07 months & & \\
\hline \multicolumn{7}{|c|}{ Restricted log likelihood } \\
\hline \multirow{2}{*}{\multicolumn{2}{|c|}{$\underset{k \text {-value }}{\beta_{k i, s t=1}}=\beta_{k i, s t=2} k=\{1,2,3\}$}} & & & $-7,924.83$ & & \\
\hline & & & & 0.01 & & \\
\hline
\end{tabular}
standard errors are in parentheses. The state transition probabilities are ruled by a constant and by the residuals from regressing the natural logarithm of total bank credit of all commercial banks on a time trend, CreditResid. 
Table 9

Bivariate Markov Switching Model.

The table reports results for three bivarite Markov Switching models estimated across two decile portfolios having the lowest or highest opacity level. Opacity is captured as the linear combination of the first principal component derived from the following firm-level variables: property plant and equipment over total assets, $\log$ of age, log of size (shares outstanding times price), book-to-market, discretionary current accruals computed as in Jones (1991).

$$
\text { Panel A }
$$

Panel A reports the results for the following model with time varying transition probability estimated across opaque and transparent portfolios:

$$
\begin{gathered}
r_{i, t}=\beta_{0 i, s t}+\beta_{1 i, s t}(1 \text { moTBil })_{t-1}+\beta_{2 i, s t}(\text { Def })_{t-1}+\beta_{3 i}(\text { Dividend Yield })_{t-1}+\varepsilon_{i t} \\
p_{i t}=\mathrm{P}\left(S_{i, t}=1 \mid S_{i, t-1}=1, Y_{t-1}\right)=\phi\left[\prod_{0 i, s t}+\prod_{1 i}\left(\text { CreditResid }_{t-1}\right)\right] \\
q_{i t}=\left(S_{i, t}=2 \mid S_{i, t-1}=2, Y_{t-1}\right)=\phi\left[\prod_{2 i, s t}+\prod_{3 i}\left(\text { CreditResid }_{t-1}\right)\right], i=\{1,10\}
\end{gathered}
$$

\begin{tabular}{|c|c|c|c|}
\hline \multirow{2}{*}{ Parameters } & & \multicolumn{2}{|c|}{ Opaque Portfolios } \\
\hline & & Low Opacity & High Opacity \\
\hline \multicolumn{4}{|c|}{ Mean parameters } \\
\hline \multirow[t]{3}{*}{ State 1} & Constant & $-0.587(0.73)$ & $-1.051(1.13)$ \\
\hline & $1 \mathrm{mo}$ T-Bill rate & $-2.796(1.06)$ & $-6.294(1.85)$ \\
\hline & Default premium & $2.264(0.51)$ & $4.544(0.99)$ \\
\hline \multirow[t]{3}{*}{ State 2} & Constant & $0.653(2.65)$ & $4.241(4.79)$ \\
\hline & $1 \mathrm{mo}$ T-Bill rate & $0.577(3.72)$ & $-2.758(7.84)$ \\
\hline & Default premium & $-1.364(1.61)$ & $-2.178(2.73)$ \\
\hline State 1,2 & Dividend Yield & $0.159(0.30)$ & $0.546(0.53)$ \\
\hline \multicolumn{4}{|c|}{ Variance parameters } \\
\hline \multicolumn{2}{|l|}{ State 1} & $10.295(1.08)$ & $27.265(3.04)$ \\
\hline \multicolumn{2}{|l|}{ State 2} & $48.852(6.29)$ & $169.560(21.60)$ \\
\hline \multicolumn{4}{|c|}{ Transition Prob. Parameters } \\
\hline \multirow[t]{2}{*}{ State 1} & Constant & \multicolumn{2}{|c|}{$1.227(0.15)$} \\
\hline & Credit & \multicolumn{2}{|c|}{$1.069(1.54)$} \\
\hline \multirow[t]{2}{*}{ State 2} & Constant & \multicolumn{2}{|c|}{$-0.719(0.17)$} \\
\hline & Credit & \multicolumn{2}{|c|}{$-0.699(2.17)$} \\
\hline \multicolumn{2}{|c|}{ Log likelihood value } & \multicolumn{2}{|c|}{$-3,243.66$} \\
\hline \multicolumn{4}{|c|}{ Duration of Regimes } \\
\hline \multicolumn{2}{|l|}{ State 1} & \multicolumn{2}{|c|}{9.08 months } \\
\hline \multicolumn{2}{|l|}{ State 2} & \multicolumn{2}{|c|}{4.24 months } \\
\hline \multicolumn{2}{|l|}{$\mathrm{AIC} / \mathrm{BIC}$} & \multicolumn{2}{|c|}{$6,531.30 / 6,639.70$} \\
\hline \multicolumn{4}{|c|}{ Restricted log likelihood } \\
\hline \multicolumn{2}{|c|}{$\beta_{k i, s t=1}=\beta_{k i, s t=2}, k=\{1,2,3\}$} & \multicolumn{2}{|c|}{$-3,248.87$} \\
\hline \multicolumn{2}{|l|}{ p-value } & \multicolumn{2}{|c|}{0.02} \\
\hline
\end{tabular}

where $\varepsilon_{\mathrm{t}}^{\mathrm{i}} \sim \mathrm{N}\left(0, \sigma_{\mathrm{i} 0, \mathrm{st}}^{2}\right), \mathrm{S}_{\mathrm{t}}=\{1,2\}$ and $\phi$ is the cumulative density function under the normality assumption. The standard errors are in parentheses. The state transition probabilities are ruled by a constant and by the residuals from regressing the natural logarithm of total bank credit of all commercial banks on a time trend, CreditResid. 
Table 9, continued

Panel B

Panel B reports the results for the following model with time varying transition probability estimated across opaque and transparent portfolios:

$$
\begin{gathered}
r_{i, t}=\beta_{0 i, s t}+\beta_{1 i, s t}(1 \text { moTBil })_{t-1}+\beta_{2 i, s t}(\text { Def })_{t-1}+\beta_{3 i}(\text { Dividend Yield })_{t-1}+\beta_{4 i, s t}\left({\text { CreditResid })_{t-1}+\varepsilon_{i t}}\right. \\
p_{i t}=\mathrm{P}\left(S_{i, t}=1 \mid S_{i, t-1}=1, Y_{t-1}\right)=\phi\left[\prod_{0 i, s t}\right] \\
q_{i t}=\mathrm{P}\left(S_{i, t}=2 \mid S_{i, t-1}=2, Y_{t-1}\right)=\phi\left[\prod_{1 i, s t}\right], \quad i=\{1,10\}
\end{gathered}
$$

\begin{tabular}{|c|c|c|c|}
\hline & & \multicolumn{2}{|c|}{ Opaque Portfolios } \\
\hline \multicolumn{2}{|l|}{ Parameters } & Low Opacity & High Opacity \\
\hline \multicolumn{4}{|c|}{ Mean parameters } \\
\hline \multirow[t]{4}{*}{ State 1} & Constant & $-0.485(0.73)$ & $-0.758(1.10)$ \\
\hline & $1 \mathrm{mo}$ T-Bill rate & $-4.332(1.17)$ & $-8.119(2.01)$ \\
\hline & Default premium & $2.154(0.52)$ & $4.664(0.99)$ \\
\hline & Credit Residuals & $5.538(2.79)$ & $6.071(5.06)$ \\
\hline \multirow[t]{4}{*}{ State 2} & Constant & $0.457(2.74)$ & $2.780(4.81)$ \\
\hline & $1 \mathrm{mo}$ T-Bill rate & $0.492(3.75)$ & $1.157(7.77)$ \\
\hline & Default premium & $-1.590(1.71)$ & $-2.335(2.65)$ \\
\hline & Credit Residuals & $0.752(10.29)$ & $-4.219(19.89)$ \\
\hline State 1,2 & Dividend Yield & $0.335(0.32)$ & $0.576(0.55)$ \\
\hline \multicolumn{4}{|c|}{ Variance parameters } \\
\hline \multicolumn{2}{|l|}{ State 1} & $10.103(1.06)$ & $26.474(3.02)$ \\
\hline \multicolumn{2}{|l|}{ State 2} & $48.573(6.45)$ & $169.617(21.73)$ \\
\hline \multicolumn{4}{|c|}{ Transition Prob. Parameters } \\
\hline State 1 & Constant & \multicolumn{2}{|c|}{$1.183(0.15)$} \\
\hline State 2 & Constant & \multicolumn{2}{|c|}{$-0.665(0.17)$} \\
\hline Log likelihs & & \multicolumn{2}{|c|}{$-3,241.54$} \\
\hline \multicolumn{4}{|c|}{ Duration of Regimes } \\
\hline State 1 & & \multicolumn{2}{|c|}{8.44 months } \\
\hline State 2 & & \multicolumn{2}{|c|}{3.95 months } \\
\hline $\mathrm{AIC} / \mathrm{BIC}$ & & \multicolumn{2}{|c|}{$6,531.07 / 6,649.33$} \\
\hline \multicolumn{4}{|c|}{ Restricted log likelihood } \\
\hline \multicolumn{2}{|c|}{$\beta_{k i, s t=1}=\beta_{k i, s t=2}, k=\{1,2,3\}$} & \multicolumn{2}{|c|}{$-3,246.94$} \\
\hline \multicolumn{2}{|l|}{$\mathrm{p}$-value } & \multicolumn{2}{|c|}{0.03} \\
\hline
\end{tabular}

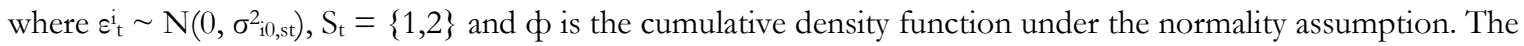
standard errors are in parentheses. The state transition probabilities are ruled by a constant. 
Table 9, continued

\section{Panel C}

Panel $\mathrm{C}$ reports the results for the following model with constant transition probability estimated across opaque and transparent portfolios:

$$
\begin{gathered}
r_{i, t}=\beta_{0 i, s t}+\beta_{1 i, s t}(1 \text { moTBil })_{t-1}+\beta_{2 i, s t}(\text { Def })_{t-1}+\beta_{3 i}(\text { Dividend Yield })_{t-1}+\beta_{4 i, s t}(\text { CreditResid })_{t-1}+\varepsilon_{i t} \\
p_{i t}=\mathrm{P}\left(S_{i, t}=1 \mid S_{i, t-1}=1, Y_{t-1}\right)=\phi\left[\prod_{0 i}\right] \\
q_{i t}=\mathrm{P}\left(S_{i, t}=2 \mid S_{i, t-1}=2, Y_{t-1}\right)=\phi\left[\prod_{0 i}\right], \quad i=\{1,10\}
\end{gathered}
$$

\begin{tabular}{|c|c|c|c|}
\hline & & \multicolumn{2}{|c|}{ Opaque Portfolios } \\
\hline \multicolumn{2}{|l|}{ Parameters } & Low Opacity & High Opacity \\
\hline \multicolumn{4}{|c|}{ Mean parameters } \\
\hline \multirow[t]{4}{*}{ State 1} & Constant & $-0.048(0.53)$ & $-0.416(0.81)$ \\
\hline & $1 \mathrm{mo}$ T-Bill rate & $-3.647(1.09)$ & $-7.433(1.79)$ \\
\hline & Default premium & $1.381(0.58)$ & $2.579(0.90)$ \\
\hline & Credit Residuals & $4.565(2.67)$ & $6.327(4.16)$ \\
\hline \multirow[t]{4}{*}{ State 2} & Constant & $-2.520(3.08)$ & $6.257(3.57)$ \\
\hline & $1 \mathrm{mo}$ T-Bill rate & $9.177(4.61)$ & $-0.825(1.00)$ \\
\hline & Default premium & $-1.096(1.76)$ & $-2.465(3.38)$ \\
\hline & Credit Residuals & $4.685(15.37)$ & $-6.471(33.83)$ \\
\hline State 1,2 & Dividend Yield & $0.270(0.29)$ & $0.958(0.49)$ \\
\hline \multicolumn{4}{|c|}{ Variance parameters } \\
\hline \multicolumn{2}{|l|}{ State 1} & $15.540(1.47)$ & $37.976(3.72)$ \\
\hline \multicolumn{2}{|l|}{ State 2} & $59.279(10.74)$ & $244.213(44.99)$ \\
\hline \multicolumn{2}{|c|}{ Log likelihood value } & \multicolumn{2}{|c|}{$-3,117.39$} \\
\hline \multicolumn{4}{|c|}{ Duration of Regimes } \\
\hline \multicolumn{2}{|l|}{ State 1} & \multicolumn{2}{|c|}{18.00 months } \\
\hline \multicolumn{2}{|l|}{ State 2} & \multicolumn{2}{|c|}{3.30 months } \\
\hline \multicolumn{2}{|l|}{$\mathrm{AIC} / \mathrm{BIC}$} & \multicolumn{2}{|c|}{$6,286.78 / 6,414.90$} \\
\hline \multicolumn{4}{|c|}{ Restricted log likelihood } \\
\hline \multicolumn{2}{|c|}{$\beta_{k i, s t=1}=\beta_{k i, s t=2}, k=\{1,2,3\}$} & \multicolumn{2}{|c|}{$-3,123.04$} \\
\hline \multicolumn{2}{|l|}{$\mathrm{p}$-value } & \multicolumn{2}{|c|}{0.02} \\
\hline
\end{tabular}

where $\varepsilon_{\mathrm{t}}^{\mathrm{i}_{\mathrm{t}}} \sim \mathrm{N}\left(0, \sigma_{\mathrm{i} 0, \mathrm{st}}^{2}\right), \mathrm{S}_{\mathrm{t}}=\{1,2\}$ and $\phi$ is the cumulative density function under the normality assumption. The standard errors are in parentheses. The state transition probabilities are constant. 


\section{Table 10}

Bivariate Markov Switching Model with constant variance.

The table reports results for two bivariate Markov Switching models estimated across two decile portfolios having the lowest or highest opacity level. Opacity is captured as the linear combination of the first principal component derived from the following firm-level variables: property plant and equipment over total assets, log of age, log of size (shares outstanding times price), book-to-market, discretionary current accruals computed as in Jones (1991).

\section{Panel A}

Panel A reports results for the following Markov Switching model with time varying transition probability estimated across two decile portfolios having the lowest and highest opacity index:

$$
\begin{gathered}
r_{i, t}=\beta_{0 i, s t}+\beta_{1 i, s t}(1 \text { moTBil })_{t-1}+\beta_{2 i, s t}(\text { Def })_{t-1}+\beta_{3 i, s t}(\text { DivYld })_{t-1}+\varepsilon_{i t} \\
p_{i t}=\mathrm{P}\left(S_{i, t}=1 \mid S_{i, t-1}=1, Y_{t-1}\right)=\phi\left[\prod_{0 i, s t}+\prod_{1 i}\left(\text { CreditResid }_{t-2}\right)\right] \\
q_{i t}=\left(S_{i, t}=2 \mid S_{i, t-1}=2, Y_{t-1}\right)=\phi\left[\prod_{2 i, s t}+\prod_{3 i}\left(\text { CreditResid }_{t-2}\right)\right], i=\{1,10\}
\end{gathered}
$$

where $\varepsilon_{\mathrm{t}}^{\mathrm{i}} \sim \mathrm{N}\left(0, \sigma^{2}{ }_{\mathrm{i} 0}\right), \mathrm{S}_{\mathrm{t}}=\{1,2\}$ and $\phi$ is the cumulative density function under the normality assumption. The standard errors are in parentheses. The state transition probabilities are ruled by a constant and by the residuals from regressing the natural logarithm of total bank credit of all commercial banks on a time trend, CreditResid. The variance is kept constant across states.

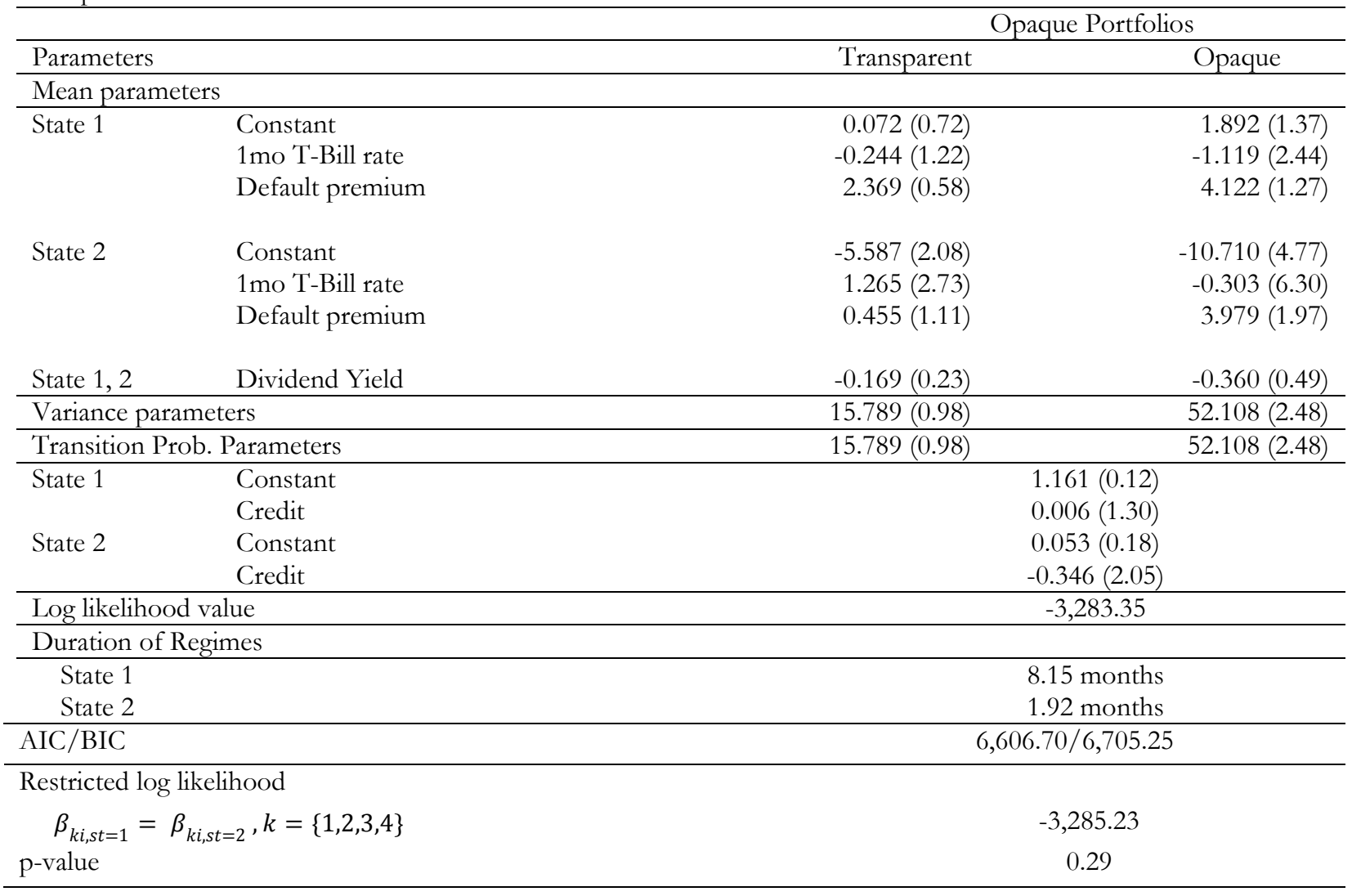


Table 10, continued

Panel B

Panel B reports results for the following Markov Switching model with time varying transition probability estimated across two decile portfolios having the lowest and highest opacity index:

$$
\begin{gathered}
r_{i, t}=\beta_{0 i, s t}+\beta_{1 i, s t}(1 \text { moTBil })_{t-1}+\beta_{2 i, s t}(\text { Def })_{t-1}+\beta_{3 i, s t}(\text { DivYld })_{t-1}+\beta_{4 i, s t}(\text { CreditResid })_{t-1}+\varepsilon_{i t} \\
p_{i t}=\mathrm{P}\left(S_{i, t}=1 \mid S_{i, t-1}=1, Y_{t-1}\right)=\phi\left[\prod_{0 i, s t}\right] \\
q_{i t}=\left(S_{i, t}=2 \mid S_{i, t-1}=2, Y_{t-1}\right)=\phi\left[\prod_{1 i, s t}\right], i=\{1,10\}
\end{gathered}
$$

where $\varepsilon_{\mathrm{t}}^{\mathrm{i}} \sim \mathrm{N}\left(0, \sigma^{2}{ }_{\mathrm{i} 0}\right), \mathrm{S}_{\mathrm{t}}=\{1,2\}$ and $\phi$ is the cumulative density function under the normality assumption. The

\begin{tabular}{|c|c|c|c|}
\hline \multirow{2}{*}{ Parameter } & & \multicolumn{2}{|c|}{ Opaque Portfolios } \\
\hline & & Transparent & Opaque \\
\hline \multicolumn{4}{|c|}{ Mean parameters } \\
\hline \multirow[t]{4}{*}{ State 1} & Constant & $-0.025(0.70)$ & $1.605(1.26)$ \\
\hline & 1mo T-Bill rate & $-0.687(1.29)$ & $-0.656(2.49)$ \\
\hline & Default premium & $2.323(0.59)$ & $4.321(1.28)$ \\
\hline & Credit Residuals & $0.583(2.97)$ & $-6.156(5.77)$ \\
\hline \multirow[t]{4}{*}{ State 2} & Constant & $-7.571(2.33)$ & $-13.476(5.44)$ \\
\hline & $1 \mathrm{mo}$ T-Bill rate & $1.192(3.11)$ & $0.237(6.97)$ \\
\hline & Default premium & $1.316(1.29)$ & $5.448(2.34)$ \\
\hline & Credit Residuals & $-11.878(6.99)$ & $-18.939(17.14)$ \\
\hline State 1,2 & Dividend Yield & $-0.113(0.26)$ & $-0.501(0.54)$ \\
\hline \multicolumn{2}{|c|}{ Variance parameters } & $15.793(1.02)$ & $53.053(2.45)$ \\
\hline \multicolumn{2}{|c|}{ Transition Prob. Parameters } & $15.793(1.02)$ & $53.053(2.45)$ \\
\hline State 1 & Constant & \multicolumn{2}{|c|}{$1.274(0.12)$} \\
\hline State 2 & Constant & \multicolumn{2}{|c|}{$0.102(0.19)$} \\
\hline \multicolumn{2}{|c|}{ Log likelihood value } & \multicolumn{2}{|c|}{$-3,281.49$} \\
\hline \multicolumn{4}{|c|}{ Duration of Regimes } \\
\hline State 1 & & \multicolumn{2}{|c|}{9.87 months } \\
\hline State 2 & & \multicolumn{2}{|c|}{1.85 months } \\
\hline $\mathrm{AIC} / \mathrm{BIC}$ & & \multicolumn{2}{|c|}{$6,606.99 / 6,715.39$} \\
\hline \multicolumn{4}{|c|}{ Restricted log likelihood } \\
\hline \multicolumn{2}{|c|}{$\beta_{k i, s t=1}=\beta_{k i, s t=2}, k=\{1,2,3,4\}$} & \multicolumn{2}{|c|}{$-3,284.70$} \\
\hline \multicolumn{2}{|c|}{$\mathrm{p}$-value } & \multicolumn{2}{|c|}{0.10} \\
\hline
\end{tabular}
standard errors are in parentheses. The state transition probabilities are ruled by a constant. The variance is kept constant across states. 


\section{Table 11}

Bivariate Markov Switching Model.

The table reports results for three univariate Markov Switching models simultaneously estimated across two decile portfolios having the lowest and highest opacity index. Opacity is captured as the linear combination of the first principal component derived from the following firm-level variables: property plant and equipment over total assets, log of age, log of size (shares outstanding times price), book-to-market, discretionary current accruals computed as in Jones (1991).

The table reports the results for the following model with time varying transition probability estimated separately for opaque and transparent portfolios:

$$
\begin{gathered}
r_{i, t}=\beta_{0 i, s t}+\beta_{1 i, s t}(1 \text { moTBil })_{t-1}+\beta_{2 i, s t}(\text { Def })_{t-1}+\beta_{3 i, s t}(\text { CreditResid })_{t-1}+\beta_{4 i}(\text { DivYld })_{t-1}+\varepsilon_{i t} \\
p_{i t}=\mathrm{P}\left(S_{i, t}=1 \mid S_{i, t-1}=1, Y_{t-1}\right)=\phi\left[\prod_{0 i, s t}+\prod_{1 i}\left(C L I_{t-2}\right)\right] \\
q_{i t}=\left(S_{i, t}=2 \mid S_{i, t-1}=2, Y_{t-1}\right)=\phi\left[\prod_{2 i, s t}+\prod_{3 i}\left(C L I_{t-2}\right)\right], i=\{1,10\}
\end{gathered}
$$

where $\varepsilon_{\mathrm{t}}^{\mathrm{i}} \sim \mathrm{N}\left(0, \sigma_{\mathrm{i} 0, \mathrm{st}}^{2}\right), \mathrm{S}_{\mathrm{t}}=\{1,2\}$ and $\phi$ is the cumulative density function under the normality assumption. The

\begin{tabular}{|c|c|c|c|}
\hline \multirow{2}{*}{ Parameters } & & \multicolumn{2}{|c|}{ Opaque Portfolios } \\
\hline & & Transparent & Opaque \\
\hline \multicolumn{4}{|c|}{ Mean parameters } \\
\hline \multirow[t]{4}{*}{ State 1} & Constant & $-0.440(0.73)$ & $-0.413(1.10)$ \\
\hline & $1 \mathrm{mo}$ T-Bill rate & $-4.437(1.20)$ & $-5.332(1.99)$ \\
\hline & Default premium & $2.075(0.53)$ & $4.572(0.98)$ \\
\hline & Credit & $5.444(2.83)$ & $2.923(5.19)$ \\
\hline \multirow[t]{4}{*}{ State 2} & Constant & $0.126(2.96)$ & $2.476(5.12)$ \\
\hline & $1 \mathrm{mo}$ T-Bill rate & $1.089(4.03)$ & $2.290(8.27)$ \\
\hline & Default premium & $-1.751(1.85)$ & $-1.435(2.89)$ \\
\hline & Credit & $0.355(11.29)$ & $-6.189(21.69)$ \\
\hline State 1,2 & Dividend Yield & $0.380(0.32)$ & $0.145(0.55)$ \\
\hline \multicolumn{4}{|c|}{ Variance parameters } \\
\hline \multicolumn{2}{|l|}{ State 1} & $10.477(1.08)$ & $28.070(3.05)$ \\
\hline \multicolumn{2}{|l|}{ State 2} & $51.993(7.45)$ & $180.62(24.94)$ \\
\hline \multicolumn{2}{|c|}{ Transition Prob. Parameters } & $15.793(1.02)$ & $53.053(2.45)$ \\
\hline \multirow[t]{2}{*}{ State 1} & Constant & \multicolumn{2}{|c|}{$1.130(0.23)$} \\
\hline & CLI & \multicolumn{2}{|c|}{$0.038(0.06)$} \\
\hline \multirow[t]{2}{*}{ State 2} & Constant & \multicolumn{2}{|c|}{$-0.698(0.22)$} \\
\hline & CLI & \multicolumn{2}{|c|}{$0.022(0.06)$} \\
\hline \multicolumn{2}{|c|}{ Log likelihood value } & \multicolumn{2}{|c|}{$-3,242.494$} \\
\hline \multicolumn{4}{|c|}{ Duration of Regimes } \\
\hline \multicolumn{2}{|l|}{ State 1} & \multicolumn{2}{|c|}{9.08 months } \\
\hline State 2 & & \multicolumn{2}{|c|}{3.82 months } \\
\hline \multicolumn{4}{|l|}{$\mathrm{AIC} / \mathrm{BIC}$} \\
\hline \multicolumn{4}{|c|}{ Restricted log likelihood } \\
\hline \multicolumn{2}{|c|}{$\beta_{k i, s t=1}=\beta_{k i, s t=2}, k=\{1,2,3,4\}$} & \multicolumn{2}{|c|}{$-3,245.194$} \\
\hline \multicolumn{2}{|l|}{$\mathrm{p}$-value } & \multicolumn{2}{|c|}{0.25} \\
\hline
\end{tabular}
standard errors are in parentheses. The state transition probabilities are ruled by a constant and by the two-month lagged annual rate of change in the composite leading indicator, CLI. 


\section{Table 12}

The credit cycle, leverage, and excess returns.

This table reports standardize parameter estimates and statistical significance for six variations of the following panel OLS model:

$$
r_{\mathrm{it}}=\beta_{0}+\beta_{1} M K T_{\mathrm{t}}+\beta_{2} S M B_{\mathrm{t}}+\beta_{3} H M L_{\mathrm{t}}+\beta_{4} O M T_{\mathrm{t}}+\beta_{5} \text { Leverage }_{\mathrm{it}}+\beta_{6} \text { Dummy }_{\mathrm{t}}+\beta_{7} \text { CreditGrowth }_{\mathrm{t}-1}+\varepsilon_{i t}
$$

where monthly excess returns, $r_{t}$, are calculated as the difference between firms monthly returns and the onemonth Treasury Bill rate. $M K T$ is the excess return on the market; SMB captures the size effect; HML captures the value effect. The market, size, and value factors are retrieved from the Kenneth French library. The OMT factor (Opaque-Minus-Transparent) is computed as the difference between returns of opaque and transparent portfolios. The opacity breakpoint was the $10^{\text {th }}$ and $90^{\text {th }}$ percentile of the opacity index at the end of June t-1. The CMU factor (Constrained-Minus-Unconstrained) is computed as the difference between returns of the most financially constrained and the least financially constrained according to the $\mathrm{KZ}$ index. The KZ index breakpoint was the $10^{\text {th }}$ and the $90^{\text {th }}$ percentile. Leverage is computed as the ratio of long-term debt and debt in current liabilities over market value of equity. Dummy captures periods of low credit and it equals 1 in periods of credit level below the trend, and 0 otherwise; CreditGrowth is the growth in credit residuals from regressing the natural logarithm of total bank credit of all commercial banks on a time trend.

\begin{tabular}{|c|c|c|c|c|c|c|}
\hline Variable & Model 1 & Model 2 & Model 3 & Model 4 & Model 5 & Model 6 \\
\hline MKT & $\begin{array}{r}0.292 * * * \\
(0.00)\end{array}$ & $\begin{array}{r}0.292 * * * \\
(0.00)\end{array}$ & $\begin{array}{r}0.292 * * * \\
(0.00)\end{array}$ & $\begin{array}{r}0.295^{* * *} \\
(0.00)\end{array}$ & $\begin{array}{r}0.295^{* * *} \\
(0.00)\end{array}$ & $\begin{array}{r}0.295^{* * *} \\
(0.00)\end{array}$ \\
\hline SMB & $\begin{array}{r}0.116^{* * * *} \\
(0.00)\end{array}$ & $\begin{array}{r}0.176^{* * * *} \\
(0.00)\end{array}$ & $\begin{array}{r}0.176^{* * *} \\
(0.00)\end{array}$ & $\begin{array}{r}0.119 * * * \\
(0.00)\end{array}$ & $\begin{array}{r}0.118^{* * * *} \\
(0.00)\end{array}$ & $\begin{array}{r}0.118^{* * *} \\
(0.00)\end{array}$ \\
\hline HML & $\begin{array}{r}0.009 * * * \\
(0.00)\end{array}$ & $\begin{array}{r}-0.002 \\
(0.39)\end{array}$ & $\begin{array}{r}-0.002 \\
(0.26)\end{array}$ & $\begin{array}{r}0.012^{* * *} \\
(0.00)\end{array}$ & $\begin{array}{r}0.012^{* * *} * \\
(0.00)\end{array}$ & $\begin{array}{r}0.017 * * * \\
(0.00)\end{array}$ \\
\hline OMT & $\begin{array}{r}0.086 * * * \\
(0.00)\end{array}$ & & & $\begin{array}{r}0.085^{* * *} \\
(0.00)\end{array}$ & $\begin{array}{r}0.086^{* * *} \\
(0.00)\end{array}$ & $\begin{array}{r}0.085^{* * *} \\
(0.00)\end{array}$ \\
\hline $\mathrm{CMU}$ & & & & & & $\begin{array}{r}-0.009 * * * \\
(0.00)\end{array}$ \\
\hline Leverage & $\begin{array}{r}-0.031 * * * \\
(0.00)\end{array}$ & $\begin{array}{r}-0.030^{* * *} \\
(0.00)\end{array}$ & $\begin{array}{r}-0.031 * * * \\
(0.00)\end{array}$ & $\begin{array}{r}-0.031 * * * \\
(0.00)\end{array}$ & $\begin{array}{r}-0.031 * * * \\
(0.00)\end{array}$ & $\begin{array}{r}-0.031 * * * * \\
(0.00)\end{array}$ \\
\hline Dummyt & & $\begin{array}{r}-0.015^{* * *} \\
(0.00)\end{array}$ & & $\begin{array}{r}-0.011 * * * \\
(0.00)\end{array}$ & & \\
\hline CreditGrowth $_{\mathrm{t}-1}$ & & & $\begin{array}{r}-0.006^{* * *} \\
(0.00) \\
\end{array}$ & & $\begin{array}{r}-0.003 * * * \\
(0.00) \\
\end{array}$ & \\
\hline Intercept & Yes*** & Yes*** & Yes*** & Yes*** & Yes*** & Yes*** \\
\hline R-Squared & 0.15 & 0.14 & 0.14 & 0.15 & 0.15 & 0.15 \\
\hline
\end{tabular}




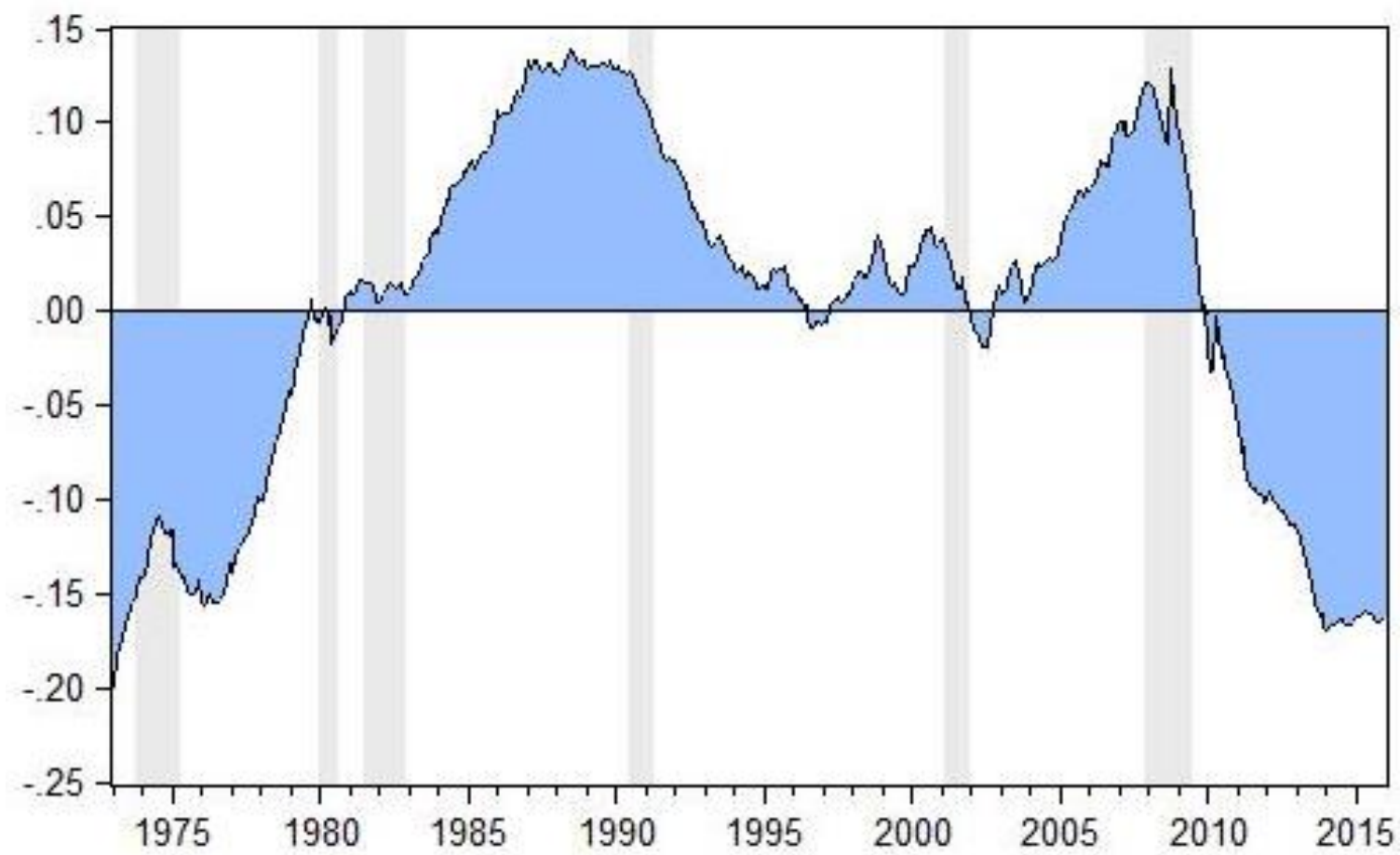

Figure 1. The credit cycle.

This figure plots Credit, the residual component of total bank credit of all commercial banks. Total bank credit is detrended by regressing the natural logarithm of total credit (TOTBKCR) on a time trend. The shaded regions depict NBER recessions. 


\section{Panel A}

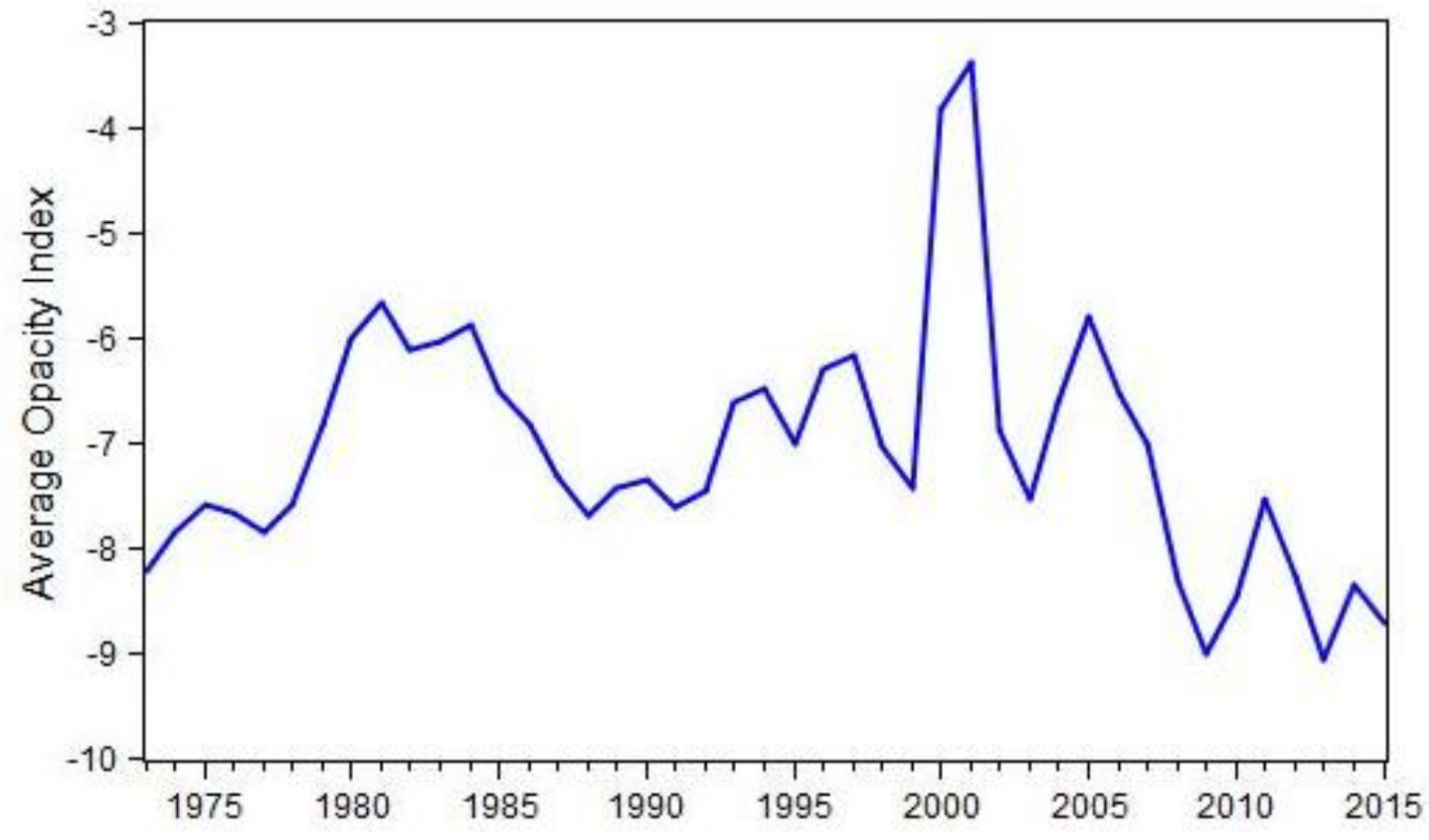

PANel B

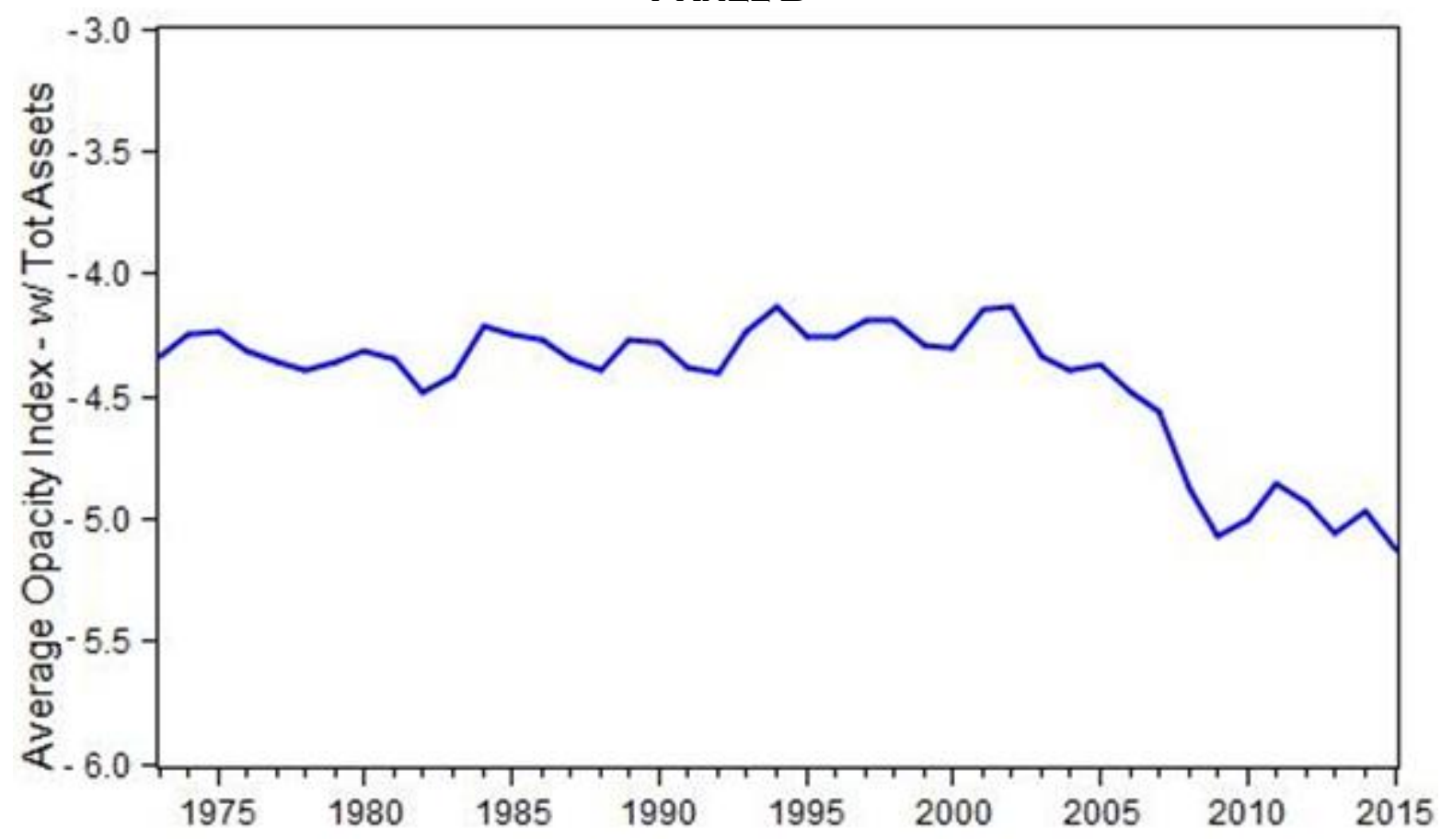

Figure 2. Average Yearly Opacity Index.

The figure represents the time-series dynamics of the yearly average opacity index. Panel A represents the opacity index having size computed as stock price times shares outstanding. Panel B represents the opacity index having size captured as total current assets. 


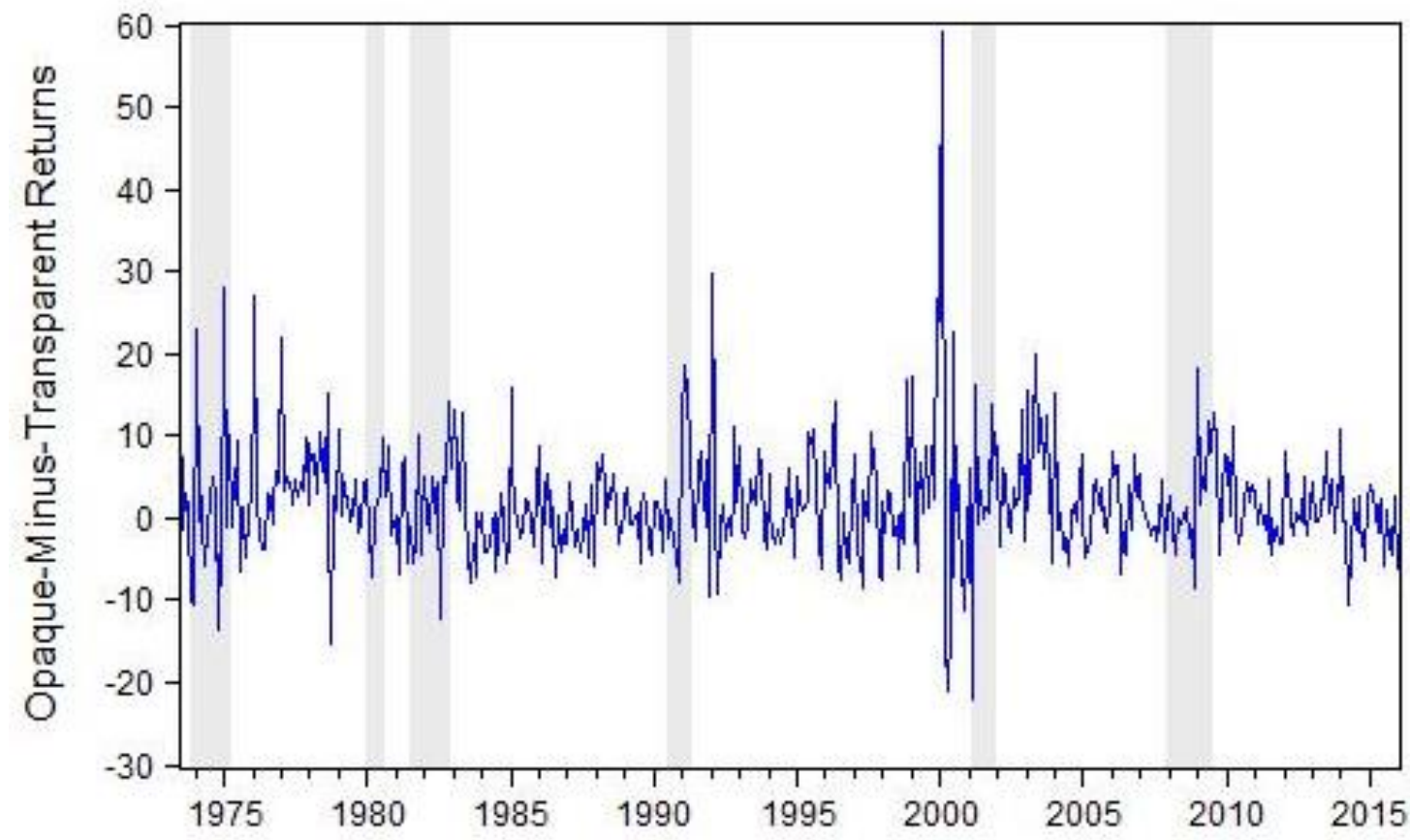

Figure 3. Opaque-Minus-Transparent.

The figure represents the OMT factor computed as the difference between returns of opaque and transparent portfolios. The opacity breakpoints were the $10^{\text {th }}$ and $90^{\text {th }}$ percentiles of the opacity index at the end of June $\mathrm{t}-1$. 


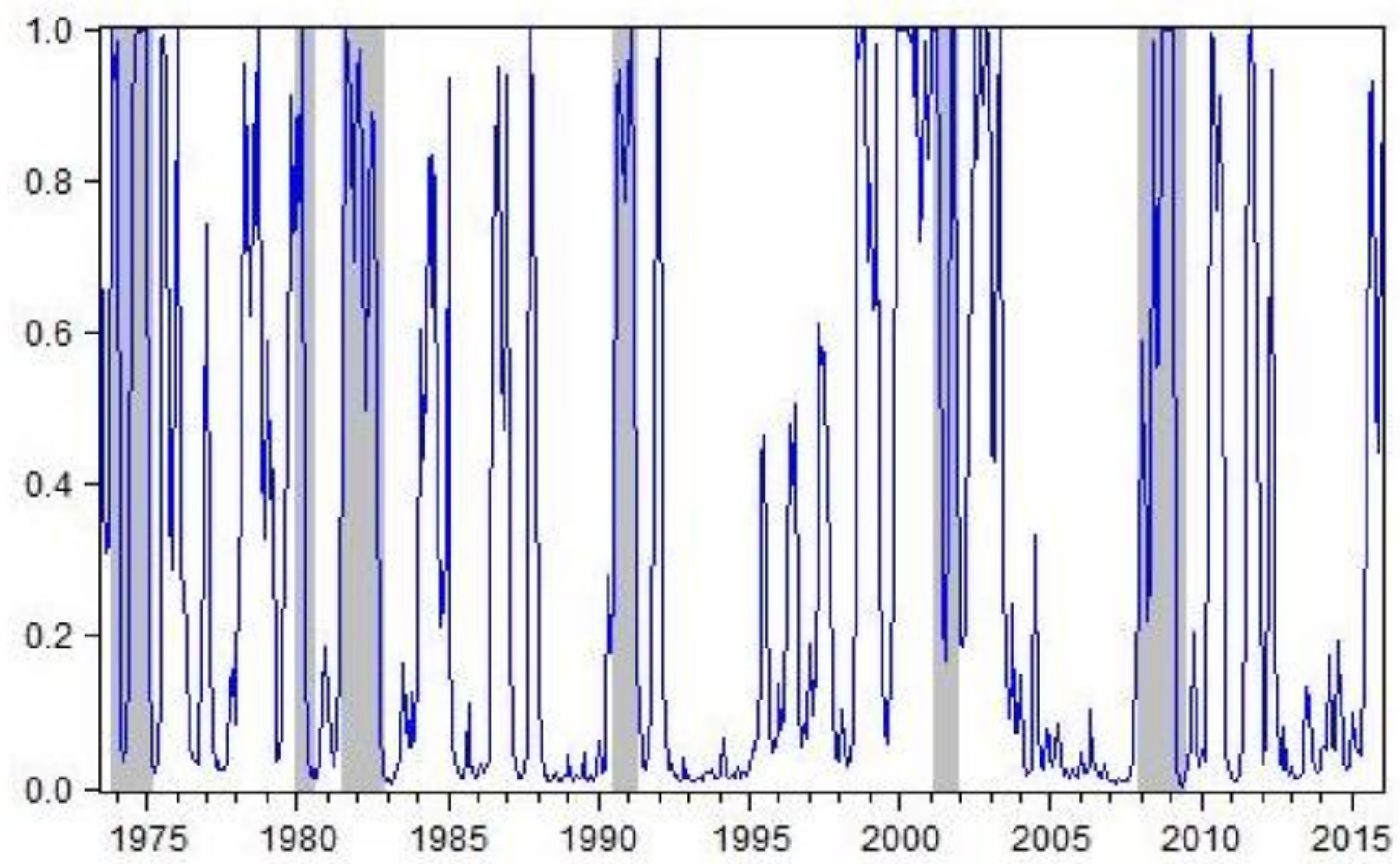

Figure 4. State 2 probabilities and NBER recessions.

This figure plot the State 2 smoothed probabilities derived from model A, Table 8 . The shaded regions represent the NBER recessions. The probabilities at time $t$ are conditional on the information at time $t-1$. 


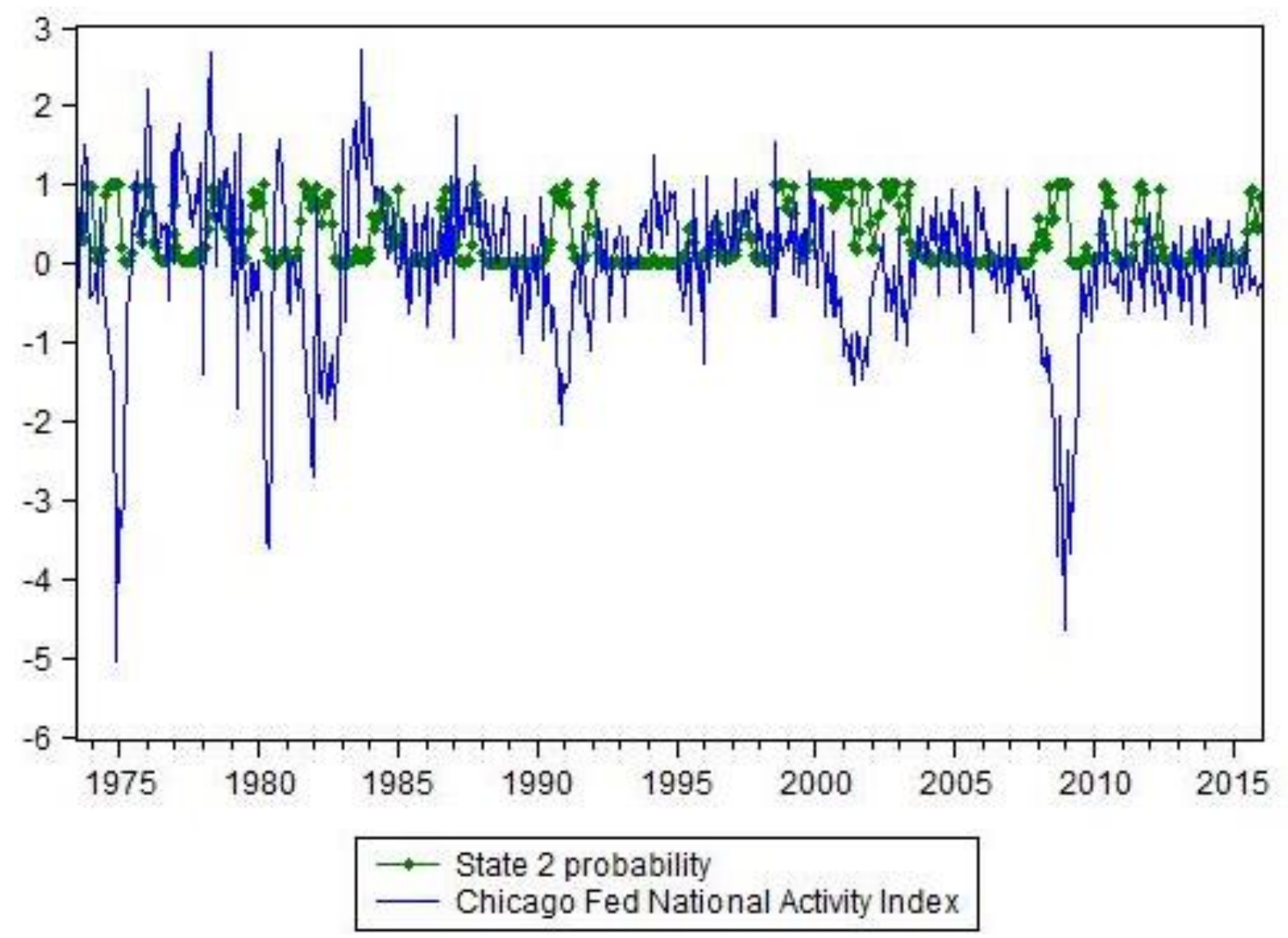

Figure 5. State 2 probabilities and the CFNAI.

This figure plots the state 2 smoothed probabilities of Model A, Table 8 along with the Chicago Fed National Activity Index (CFNAI). The CFNAI represents the level of monthly economic activity and it is computed as a combination of 85 macroeconomic series. A low CFNAI index corresponds to low economic activity. The probabilities at time $t$ are conditional on the information at time $t-1$. 


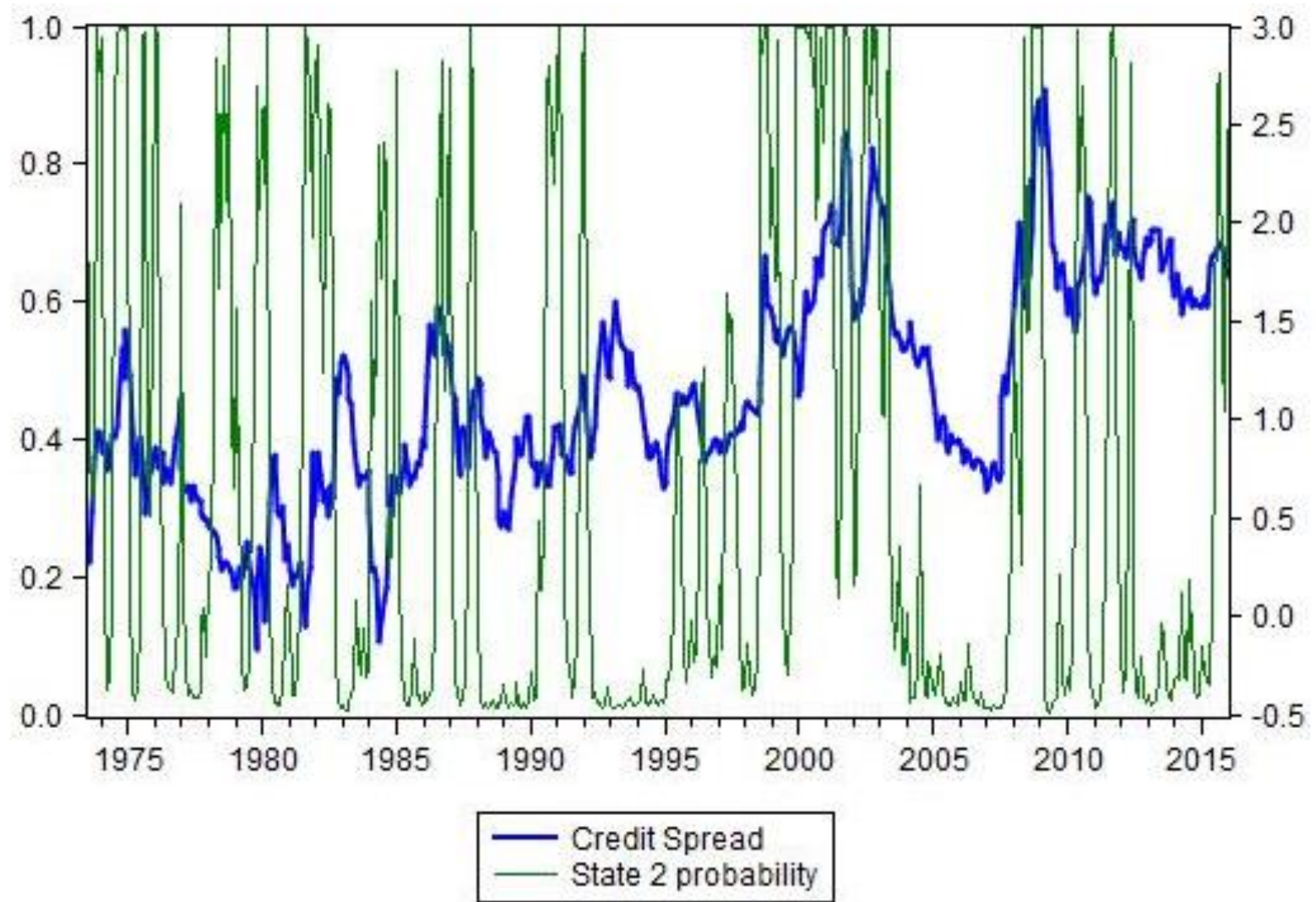

Figure 6. State 2 probabilities and the credit spread.

This figure plots the state 2 smoothed probabilities of Model A, Table 8 along with the credit spread computed as the difference between AAA corporate bond yield and the 10-year Treasury yield. The probabilities at time $t$ are conditional on the information at time $t-1$. 
TRANSPARENT

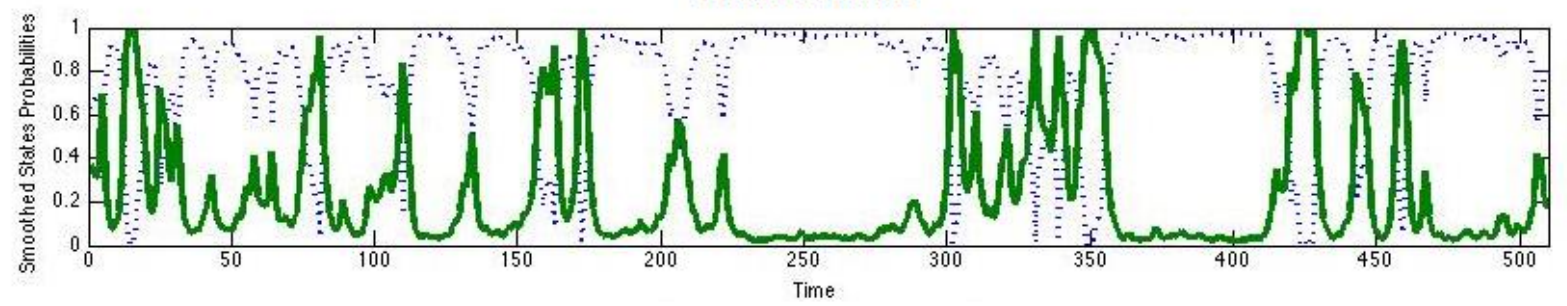

OPAQUE

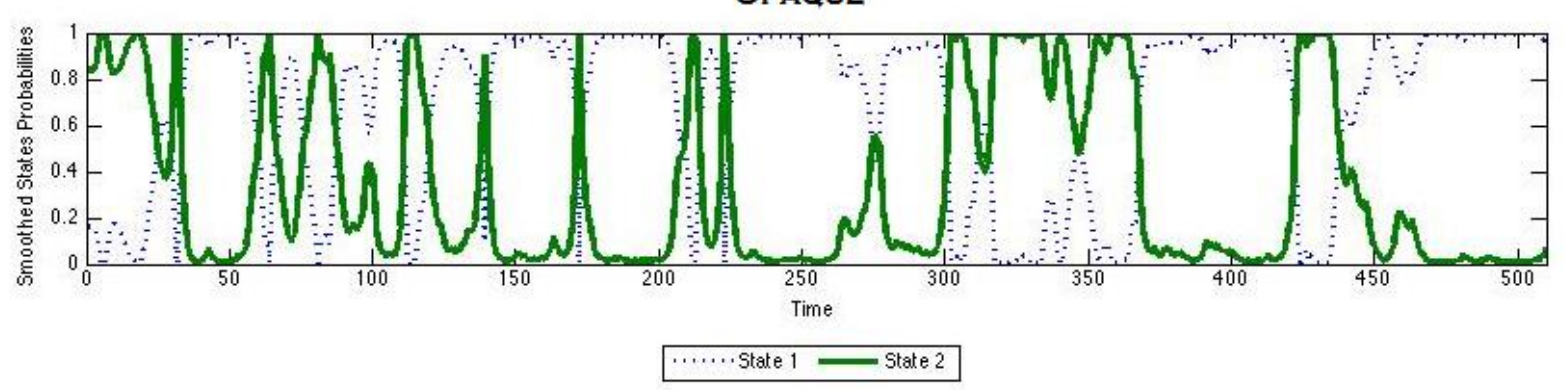

Figure 7. Smoothed state probabilities.

This figure represents the smoothed state probabilities for transparent and opaque portfolios obtained from the univariate regime switching model estimation. 
TRANSPARENT
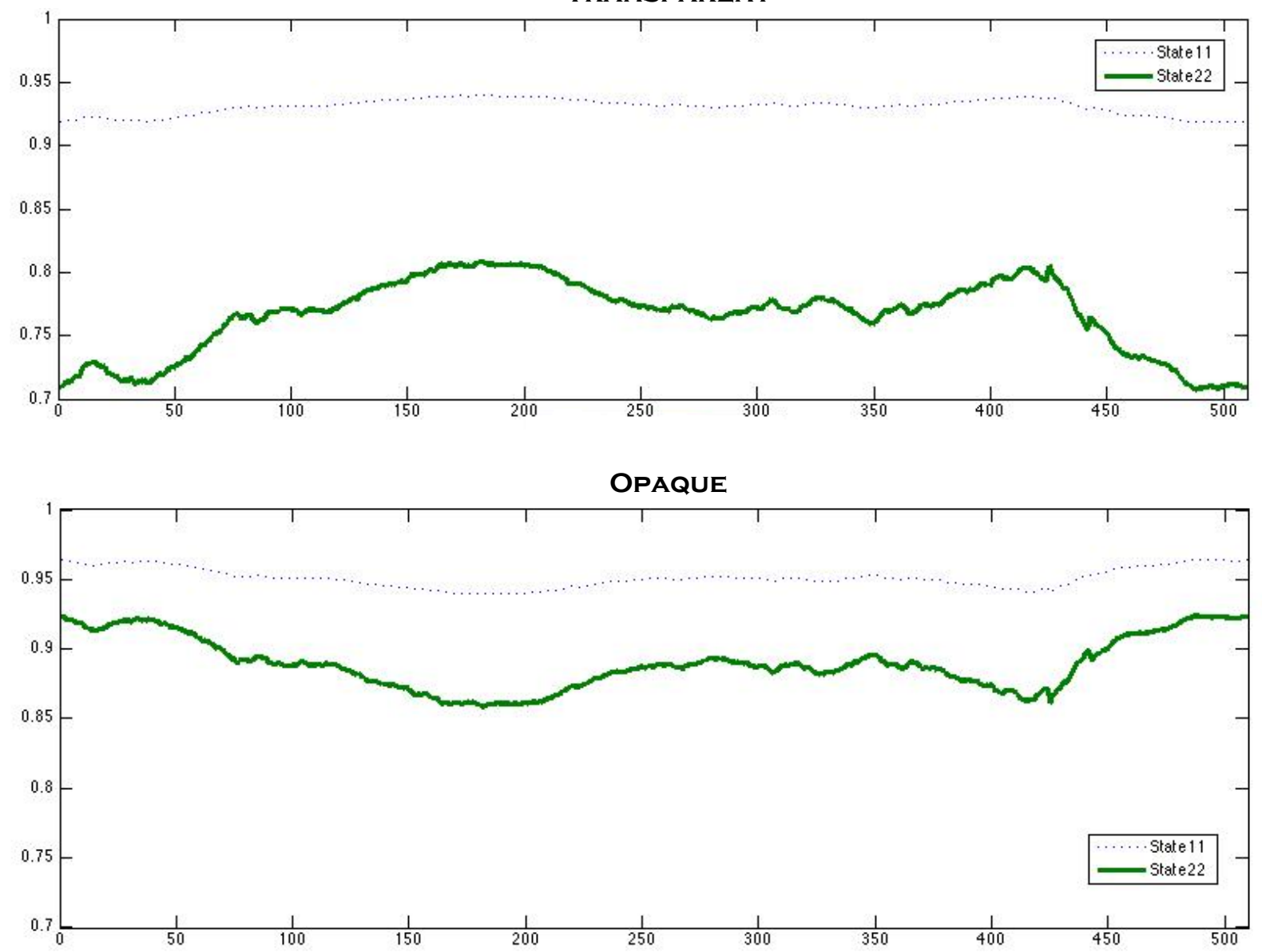

Figure 8. Transition probability for transparent and opaque portfolios.

This figure plots the time-series of the probability of staying in the current state for transparent and opaque portfolios obtained from the univariate regime switching model estimation. 


\title{
III. CaPter 2. Price Discovery along the Yield Curve: Does Unconventional Monetary Policy MaKe A DifFERENCE? ${ }^{1}$
}

\begin{abstract}
We examine the impact of unconventional monetary policy on price discovery along the yield curve by investigating the effects of quantitative easing, macroeconomic news, and security's characteristics on relative information shares. Our analysis consists of two parts: (1) we analyze the cross-sectional and time-series price informational contribution of Treasury and Eurodollar futures contracts across periods of quantitative easing, and (2) we investigate the influence of macroeconomic news on information shares. The questions addressed have important implications for the understanding of monetary policy effects on price discovery through the investor's expectations channel. Contrary to our expectations, we find that the long-term contracts do not have higher relative information shares during periods of unconventional monetary policy. We conclude that quantitative easing is not a significant driver of price discovery along the yield curve. Our findings are surprising given the effectiveness of quantitative easing in influencing longer-term rates. We advance an alternative explanation in line with the macro-finance term structure literature: futures prices contained a time-varying component that went beyond the role of expectations as drivers of the term structure of interest rates.
\end{abstract}

${ }^{1}$ This essay is based on a paper coauthored with Alexander Kurov. 


\section{Introduction}

The goal of our study is to investigate the relative informational contribution of different maturities across the yield curve in order to understand if the dynamics of price discovery reflect the impact of quantitative easing on long-term interest rates. The question addressed has important implications for understanding the effect of monetary policy on price discovery through the investor's expectations channel. While previous literature examines the market reactions to monetary policy announcements, little has been done investigating the inclusion of updated investor's expectations in market prices through a price discovery approach. We are, to the best of our knowledge, the first to examine the price discovery dynamics along the yield curve during quantitative easing periods for Treasury and Eurodollar futures contracts.

Given the effectiveness of quantitative easing policy on long term interest rates, ${ }^{1}$ news from unconventional monetary policy should be more important for the long term rates rather than the short term rates. This would lead to greater information being incorporated into long term futures contract prices and, consequently, cause higher relative information shares for long term contracts. Information shares capture the relative weight of price discovery across different maturities highlighting the market, or the security, in which the new information is first incorporated. For this reason, the relative information shares should also vary according to quantitative easing periods and new release of information.

Our analysis consists of two parts: Part I investigates the price discovery and its dynamics across contract maturities and quantitative easing periods; Part II investigates the influence of macroeconomic and policy news on relative information shares, after controlling for specific contract characteristics.

\footnotetext{
${ }^{1}$ For empirical analysis and results concerning the effectiveness of unconventional monetary policy see Gagnon, Raskin, Remache and Sack (2010), Krishnamurthy and Vissing-Jorgensen (2011), and Swanson and Williams (2014).
} 
Capturing changes in expectations is essential for understanding investor's behavior and the effects of economy-wide events on financial markets. When faced with a change in policy procedures, such as during unconventional monetary policy periods, rational investors would immediately update their holdings to reflect their new expectations influenced by the Federal Reserve Bank's policy announcements and long-term commitments. Expected changes in future macroeconomic policy and settings in fact cause changes in investor's expectations and, ultimately, movements along the yield curve (Rudebusch and Wu, 2008). The behavior of rational investors in front of monetary policy shocks should be captured through a price discovery analysis and the results should highlight the primary location of price discovery- in short-term or long-term securities.

Interest rate expectations are significant factors influencing investor's decisions, holdings, portfolio rebalancing, borrowing levels and lending patterns; as such, they should be considered as determining drivers of changes in relative information shares across assets whose values are strictly related to interest rates levels. Financial instruments such as Treasury and Eurodollar futures are found to be good predictors of monetary policy expectations and a forecasting tool of spot interest rates (Chernenko, Schwarz and Wright, 2004; Gürkaynak, Sack and Swanson, 2007; Ferrero and Nobili, 2009). Most importantly, both Treasury and Eurodollar futures are derivatives whose values are strictly connected to their underlying assets and whose contracts are often used by investors to hedge future interest rate movements. Long-term yields also reflect expectations of short-term yields and are highly sensitive to monetary policy changes. A price discovery analysis across maturities of both the Eurodollar futures contracts and the maturities of the underlying assets of Treasury futures contracts should highlight the efficacy of quantitative easing policy in influencing long-term rates.

We also expect information shares to exhibit a dynamic behavior across periods of different monetary policy. Relative information shares should differ across quantitative easing periods because 
investors are shifting their holdings after adjusting their expectations for long-term interest rates. As Burger, Lang and Rasche (1977) point out, changes in expectations coincide with changes in investor's holdings. We believe that information shares for long-term contracts should account for a higher portion of price discovery during quantitative easing periods. In our study, we identify thirty years and 9 quarters as being the long-term contracts for Treasury and Eurodollar futures, respectively. Examining the Eurodollar futures at 9 quarters in fact allows us to magnify and dissect the price discovery patterns observed at the shortest maturity of Treasuries in order to identify a long-term in a short-term setting. Lastly, we expect days of macroeconomic news to influence how information is incorporated in prices. In line with our initial hypothesis, macroeconomic information should be more important when revealed during a period of unconventional monetary policy, and its effect should be stronger for longer-term securities, the target of quantitative easing policy.

Contrary to our expectations, our analysis reveals that long-term contracts do not have higher relative information shares during periods of unconventional monetary policy, and that days of macroeconomic news do not experience different price discovery patterns. Shortest-term maturities maintain their relative importance even during unconventional monetary policy when the short-term rates were bounded at zero. Our price discovery results suggest that the short end of the yield curve moves first, followed by the medium and long-term rates. Such findings are surprising given the success of quantitative easing policy in decreasing longer-term rates while the short-term rates were bounded at zero (Krishnamurthy and Vissing-Jorgensen, 2011).

Our results do not disprove the effectiveness of unconventional monetary policy. On the other hand, our results show that quantitative easing did not disrupt the commonly observed price discovery dynamics, even though the policy specifically targeted longer-term securities. 
In order to further understand our results, in our second part of the analysis we investigate the influence of macroeconomic news on the dynamics and patterns of price discovery. It is in fact possible for the release of new information to be an additional determinant of price discovery through its influence on the informational structure of markets. Specific macroeconomic news that have been found in past literature to have an impact on investor's behavior and price discovery might also change the relative importance of information shares across maturities according to the economic circumstances - quantitative easing vs. non-quantitative easing periods. It is therefore important to further analyze the determinants of relative information shares and the drivers of price discovery patterns across contract maturities and unconventional times.

Our results lead us to an alternative explanation spanning the macro-finance term-structure literature. There are additional factors besides expectations that determine the term structure of interest rates, the overall yield curve, and the level and composition of risk. There is the need to decompose the yield curve into expectations and risk premia effects in a similar way as that adopted in Cochrane and Piazzesi (2005). Our price discovery analysis might be capturing the time-varying risk premium component effects driving the yield curve especially during a period of unconventional monetary policy. Macroeconomic factors are in fact found to be important when analyzing the term structure of interest rates (Ludvigson and Ng, 2009).

Our paper is organized as follows. Section 2 discusses the related literature to our hypothesis and motivates our analysis; Section 3 describes the sample and the construction of our dataset; Section 4 explains our three hypotheses, which are tested in the two following sections. In Sections 5 we compute the relative information shares for Treasury and Eurodollar contracts, and we discuss the observed patterns and results; in Section 6 we examine the impact of macroeconomic news and contract characteristics on relative information shares across maturities and quantitative easing periods. Section 7 provides a brief summary of the motivation behind our study and of the results. 


\section{Related Literature}

Our paper primarily relates to two strands of literature investigating the effect on price discovery from (i) monetary policy and (ii) release of macroeconomic news.

There are good reasons to expect a dynamic behavior in relative information shares across periods of unconventional monetary policy. Krishnamurthy and Vissing-Jorgensen (2011) find that unconventional policy works through different channels and the effect of QE depends strictly on the type of assets purchased by central banks. Their results show that the long-term interest rates on Treasury and safe corporate bonds are significantly decreased when the Fed purchases only Treasury securities, while the mortgage rates are the ones affected when mainly mortgage-backed securities are purchased.

Swanson and Williams (2014) find that medium- to long-term interest rates were particularly sensitive to monetary policy from 2008 to 2010, but the sensitivity for long-term rates became insignificant starting in late 2011. The Federal Reserve Bank's monetary policy actions have been successful for most of the financial crisis, and investor's expectations of monetary policy and forward guidance information are the factors driving the observed results. Given the success of unconventional monetary policy, we might observe its effectiveness also through a price discovery analysis capturing how the new information is incorporated in market prices.

The paper closest to our study is Fricke and Menkhoff (2011). The authors examine the relative information shares of the German bond futures market and find that the long-term contract - with the Bund as the underlying security - has a significant role in price discovery, but its absolute importance fluctuates. The authors try to explain the determinants of relative information shares in the European bond market and find that order flow is an information channel for price discovery more important than macroeconomic news itself. Contract characteristics seem to matter significantly for a price discovery analysis. 
Macroeconomic announcements have a significant impact on trading and prices, ${ }^{2}$ but limited work has been done on the connection between price discovery and news announcements. Mizrach and Neely (2008) ask whether the information shares change from announcement to nonannouncement days, and they find that price discovery in Treasury futures markets increases when public information is released. While macroeconomic events have a moderate effect on futures market information shares, FOMC-related events have no significant effect. Their analysis however does not include the financial crisis, a period of high uncertainty characterized by the release of information related to new policy measures.

Motivating our analysis is also Gagnon, Raskin, Remache and Sack's (2010) study where they investigate the effectiveness of Large-Scale Asset Purchases (LSAP) by the Federal Reserve. The authors find that unconventional monetary policy was effective in lowering long-term rates. The LSAP program was found to decrease the 10 -year premium between 30 and 100 basis points thanks to the portfolio balance effect - investors rebalance their portfolios due to the decrease in yield caused by the increase in Fed's purchases of long-term securities. However, unconventional monetary policy was found to influence longer-term rates the most during announcement days. Consequently, information shares for long-term rates could be influenced more on announcement days rather than throughout each quantitative easing period. There is the need to further investigate this possible channel of monetary policy particularly on days of new information release.

Chen and Gau (2010) examine the impact of news on price discovery in foreign exchange markets and reach two conclusions: (i) information is more crucial for spot rates in the Electronic Broking Services (EBS) rather than for Chicago Mercantile Exchange (CME) futures rates, and (ii)

\footnotetext{
2 For the major research concerning the impact of macroeconomic news announcements on investor's behavior and prices, see Fleming and Remolona (1999), Andersen, Bollerslev, Diebold, and Vega (2003), Boyd, Hu, and Jaganathan (2005), Bernanke and Kuttner (2005), Gürkaynak, Sack, and Swanson (2005), Basistha and Kurov (2015).
} 
the price discovery in the CME increases around macroeconomic announcements. Jian and Lo (2014) instead identify two states of the world through a regime switching model: an informed state and an uninformed state. They find that both private and public information dominate price discovery in days of macroeconomic announcements, while private information and liquidity shocks are most important for non-announcement days. Their analysis focuses only on 2-, 5- and 10-year notes and ranges from January 2004 to June 2007 thus discarding the financial crisis period, the focus of our study.

A last strand of literature strictly connected to our research question is that investigating timevarying risk premia and investor's expectations as drivers of asset prices. Overall, previous studies do confirm the existence of a time-varying risk component in asset prices, but they do not expand such intuition through a price discovery analysis. Balduzzi and Moneta (2016) price macroeconomic risk and find a counter cyclical risk premium implied in an economic news factor. The authors find that the reaction to macroeconomic announcements has a time-varying component leading to dynamic response patterns. Feroli, Kashyap, Schoenholtz and Shin (2014) find that periods of unconventional monetary policy lead to changes in perceived risk through monetary policy shocks such as the use of forward guidance. Chernenko, Schwarz and Wright (2004) empirically test the existence of risk premia and find that interest rate futures prices include both expectations and market priced risk components, therefore departing from the expectation hypothesis.

\section{Data}

In order to test our hypotheses, we use second-by-second data for Treasury and Eurodollar futures contracts. The underlying assets of Treasury futures contracts have maturities of 2, 5, 10 and 30 years. The data is gathered from Genesis Financial Technologies and spans from January $1^{\text {st }}, 2008$ 
to October $9^{\text {th }}, 2015$. The four Treasury contracts are the most traded contracts in each respective market.

The Eurodollar futures contracts data is gathered from Genesis Financial Technologies and the overall sample covers a longer time period than the Treasury dataset, ranging from December $9^{\text {th }}$, 2007 (contract with expiration on March 2008) to February 10 $0^{\text {th }}, 2016$ (contract with expiration on March 2018). The futures contracts examined have a maturity of 1, 3, 5, 9 quarters. In order to calculate the different maturities across Eurodollar futures, for each trade we computed the numbers of quarters to maturity for the underlying security and we then created four time series reflecting the contract prices for 1, 3, 5 and 9 quarters to expiration, respectively. The sample periods examined refer only to the trading days from 8:00am to 5:00pm. ${ }^{3}$

It is of crucial importance to point out that when we refer to the maturities of Treasury futures contracts throughout the text, we are actually referring to the maturity of the underlying assets Treasury notes and bonds - rather than the contract itself. When we refer to Eurodollar futures contracts, instead, we are referring to the maturity of the contract which is captured through the computation described above.

Table 1 reports the descriptive statistics for the Treasury constant maturity rates (Panel A) and the Eurodollar implied LIBOR rates (Panel B). The Treasury data was gathered from the Federal Reserve Bank of St. Louis database, while the implied LIBOR rate was computed by subtracting the Eurodollar futures price from 100. The table provides information on the securities underlying the derivative contracts examined in our study.

[Insert Table 1 around here]

\footnotetext{
${ }^{3}$ Some announcements (for example, the Nonfarm Employment announcement) are released before the markets open. For this reason, we decided to analyze trades starting from 8:00am; while the cutoff time, of $5: 00 \mathrm{pm}$ is common practice in the literature.
} 
Figures 1 and 2 show the yearly average trading volume of the number of contracts per second for the Treasury and Eurodollar futures contracts. On average, the 10-year Treasury futures contract has the highest trading volume among the four maturities and the thirty-year futures has the lowest trading volume. The most actively traded Eurodollar futures maturity in average daily volume is the 1-quarter contract, while the least traded is the 9-quarter contract. The 1-quarter Eurodollar contract during the last two years examined - 2015 and 2016 - show a sharp increase in the yearly average trading volume. The 2-year Treasury contract also exhibits an increase in average volume for the years 2014 and 2015. For both securities the increase in volume was experienced by the shortestterm futures contracts.

\section{[Insert Figures 1 and 2 about here]}

Conducting the price discovery analysis over different quantitative easing periods allows us to directly examine the dynamics of information shares across the financial crisis and unconventional monetary policy. The overall analysis for each security is conducted across both the full sample period and five selected quantitative easing periods:

- QE1 (November 25 $5^{\text {th }}, 2008$ to Mar 31 $\left.{ }^{\text {st }}, 2010\right)$;

- $\quad$ Pre-QE2 (April 1 $1^{\text {st }}, 2010$ to November 2 $\left.{ }^{\text {nd }}, 2010\right)$;

- QE2 (November $3^{\text {rd }}, 2010$ to June 30 $\left.{ }^{\text {th }}, 2011\right)$;

- $\quad$ Pre-QE3 (July $1^{\text {st }}, 2011$ to September 12 $2^{\text {th }}, 2012$ )

- QE3 (September 13 ${ }^{\text {th }}, 2012$ to October 29 $\left.9^{\text {th }}, 2014\right)$;

Quantitative easing policy differentiates itself from conventional Open Market Operation in both the size and the goal of policy actions. Conventional asset purchases by the Federal Reserve aim at causing a small effect in short-term interest rates through the Treasury bill market; unconventional monetary policy involves a large purchase of longer term securities in order to significantly influence long-term rates for specific securities and markets. 
After lowering the short-term interest rates to almost zero in mid-2008, the Federal Reserve adopted unconventional monetary policy measures and started purchasing long-term securities. The QE1 period accounted for the purchase of $\$ 1.25$ trillion of mortgage-back securities, $\$ 300$ billion in Treasury bonds and $\$ 175$ billion of agency debt securities; the QE2 accounted for the purchase of $\$ 600$ billion of long-term Treasury securities at $\$ 75$ billion per month until June $30^{\text {th }}, 2011$; QE3 accounted for an additional $\$ 40$ billion monthly purchases of mortgage-backed securities and $\$ 85$ billion of Treasuries to then be tapered to zero by the end of QE3 period.

We retrieve data on macroeconomic announcements from Bloomberg's Economic Calendar Database. The calendar reports dates, times, and figures for each US macroeconomic and policy announcement. We first consider days with at least one news announcement, we then narrow the announcements to those considered to have the most significant impact on prices. Table 2 reports the specific macroeconomic announcements that we take into consideration, along with the number of days in our sample coinciding with each specific announcement or with a day of macroeconomic news release, regardless of the type of news. We consider announcements related to real economic activity (GDP and jobless claims), prices (CPI and PPI), forward looking proxies (ISM manufacturing index), and monetary policy (FOMC announcements and the release of the meeting minutes). The choice of announcements was motivated by previous literature. ${ }^{4}$

[Insert Table 2 about here]

Of the seven specific macroeconomic news examined, announcements concerning jobless claims (GDP) occur most (least) frequently accounting for a total of 151 (22) days in the sample. Overall, we have 605 days (94\% of our final sample) experiencing at least one macroeconomic

${ }^{4}$ For an extensive overview of the effect of macroeconomic announcements on price discovery, see Mizrach and Neely (2008), Chen and Gau (2010), and Fricke and Menkhoff (2011). 
announcement, where 313 (48\% of our final sample) of these coincide with the release of one of the seven specific announcement we closely analyze.

We also take into consideration announcements that relate specifically to quantitative easing policy actions. Table 3 reports the days of our sample that coincide with these significant QE-related news announced through either FOMC statements or speeches by the Chairman of the Federal Reserve Bank. We believe it is important to consider the effect of QE-related news on price discovery even though only a small number of days coincide with our cointegrated sample.

[Insert Table 3 about here]

\section{Hypotheses}

We expect the relative contribution of information shares to vary across time and across contract maturities. This expectation is motivated by the effectiveness of unconventional monetary policy, by the different sensitivity of Treasury yields, and by the different degree of information and learning gathered by investors. Applying Swanson and Williams' (2014) findings to a price discovery analysis during unconventional monetary policy, we expect the information shares to be timevarying and the relevant price discovery market to change according to both the time period and the information gathered by investors. We advance the following hypotheses:

Hypothesis 1 (H1): Price discovery in the pre-QE and post-QE periods should occur mostly in short-term futures contracts due to the effectiveness of conventional monetary policy and to investors' familiarity with the policy procedures.

Hypothesis 2 (H2): Price discovery in the QE1, QE2, and QE3 periods should occur in long-term futures contracts due to the zero lower bound and to the effectiveness of unconventional monetary policy at influencing investors' expectations.

For what concerns the effect of macroeconomic news on the dynamics of price discovery, we expect the release of public news to have a different impact during quantitative easing periods. Macroeconomic announcements have the potential to change the information structure of markets, 
and price discovery captures how prices react to available relevant information (Chen and Gau, 2010). For this reason, we believe announcements should change the price discovery dynamics. This should be true especially during periods of unconventional monetary policy when any new information is crucial at the margin. We aim at investigating whether a day of macroeconomic announcement or specific macroeconomic news partially explain the relative information shares across time and across Treasury and Eurodollar futures contract maturities. We advance the following two additional hypotheses:

Hypothesis 3 (H3): We expect the days of macroeconomic announcements to significantly influence information shares, especially if they occur during periods of quantitative easing.

Hypothesis 4 (H4): We expect specific announcements related to macroeconomic policy to have a heterogeneous impact across information shares of different contract maturities.

The novel contribution of the study is the time-series analysis of information shares along the yield curve for securities targeted by monetary policy before, during and after the recent financial crisis. Results will highlight both the dynamics of price discovery in response to different monetary policy actions and the degree of investor's learning and inclusion of specific macroeconomic information in financial markets.

\section{Part I: Dynamics of Information Shares}

Our main goal is to look at the relative rates of price discovery for futures contract prices across maturities. In order to do this, we must compute information shares for multiple assets using Hasbrouck's (1995) price discovery methodology. The information share is a price discovery measure capturing the relative contribution of a market's innovation to the overall security's price innovation.

Both Treasury and Eurodollar futures are often used by investors to hedge future interest rate moves, and futures markets are a forecasting tool of spot interest rates (Chernenko, Schwarz and 
Wright, 2004; Ferrero and Nobili, 2009). We start by analyzing information shares for Treasury futures contracts having the underlying assets with maturities of 2,5 , ten, and thirty years. In order to further dissect the short-term maturities and given Eurodollar futures are a good forecasting tool of monetary policy expectations, we also analyze Eurodollar futures contracts having 1 quarter as the shortest futures maturity.

\section{$\underline{5.1 \text { Information shares adopting Hasbrouck (1995) price discovery model }}$}

Hasbrouck's (1995) model relies on the idea that a change in price reflects a deviation from the long-run equilibrium price. When we have multiple prices for the same security, i.e.: when securities are either traded on different markets or through different contract maturities, prices follows a random walk and have a common underlying efficient price. Therefore, prices will diverge in the short-run but converge in the long-run, and the difference between prices will be stationary (Hasbrouck, 2004).

Hasbrouck's (1995) price discovery measure - the Information Share (IS) - is widely used in the microstructure literature and it captures how much the variance of a security's price contributes to the overall variance of the changes in the underlying efficient price. In other words, the information share captures the relative price discovery occurring in each specific market. The methodology consists on estimating a Vector Error Correction Model (VECM) of the price series examined.

Following we outline the econometric procedure adopted in the price discovery analysis as explained in Hasbrouck (2002). ${ }^{5}$ Consider a price vector $p_{t}=\left[\begin{array}{llll}p_{1 t} & p_{2 t} & \ldots & p_{n t}\end{array}\right]$, where $p_{i}$ refers to the same security. We can write a VECM of order $K$ as:

$$
\Delta p_{t}=\alpha \beta p_{t-1}+\sum_{i=1}^{k} A_{i} \Delta p_{t-i}+\varepsilon_{t}
$$

\footnotetext{
5 The model is estimated using the SAS code provided in Hasbrouck (2002) available from www.stern.nyu.edu/ jhasbrou.
} 
where $\alpha$ and $\beta$ are $n \times(n-1)$ matrices with rank (n-1); $\alpha$ contains the adjustment coefficients; $\beta$ is an $(n-1)$ cointegration vector; $A_{i}$ are square matrices of order $\mathrm{n} ; \varepsilon_{t}$ is an $(n \times 1)$ vector of price innovations; and $\beta p_{t-1}$ is the $(n-1) \mathrm{x} 1$ vector of error correction terms. For example, if we look at the relationship of the Hewlett-Packard (HP) stock traded on NYSE and the NASDAQ, the error correction term will be $\beta p_{t-1}=p_{t-1}^{N Y S E}-p_{t-1}^{N A S D A Q}$.

The Vector-Moving Average (VMA) of the model can be expressed as:

$$
\Delta p_{t}=e_{t}+\left(\psi_{1} e_{t-1}+\psi_{2} e_{t-2}+\psi_{3} e_{t-3}+\cdots\right)
$$

where the vector $e_{t}$ captures the VECM residuals, $e_{t}=\left[\begin{array}{llll}e_{1 t} & e_{2 t} & \ldots & e_{n t}\end{array}\right]^{\prime}$. This allows us to compute the variance of the efficient price, the major component in the information share calculation. The efficient price, $m_{t}$, follows a random walk, $m_{t}=m_{t-1}+u_{t}$, where $u_{t}$ is the efficient price innovation. The variance of the common random-walk component of prices can thus be written as:

$$
\sigma_{u}^{2}=\psi \Omega \psi^{\prime}
$$

where $\Omega=\operatorname{Var}\left(e_{t}\right)$ and $\psi$ is the matrix of VMA coefficients. Hasbrouck (1995) shows that if $\Omega$ is diagonal, then:

$$
\Omega=\left[\begin{array}{ccc}
\sigma_{1}^{2} & 0 & 0 \\
0 & \ddots & 0 \\
0 & 0 & \sigma_{n}^{2}
\end{array}\right]
$$

and the information share for market $i$ can be computed as

$$
I S_{i}=\frac{\psi_{i}^{2} \sigma_{i}^{2}}{\sigma_{u}^{2}} .
$$


If instead $\Omega$ is a non-diagonal matrix, as it often occurs, Hasbrouck adopts a Cholesky

factorization to $\Omega$ to obtain the lower triangular matrix $M .{ }^{6}$ After the transformation, the new matrix is $\Omega=M M^{\prime}$ and the information share for market $i$ can now be calculated as:

$$
I S_{i}=\frac{(\psi M)_{i}^{2}}{\sigma_{u}^{2}}
$$

where $\psi_{i} M$ is the $i$ th element of the row matrix $\psi M$ (Hasbrouck, 1995). The information share, $\mathrm{IS}_{\mathrm{i}}$, is the proportion of the variance of the permanent component price innovation coming from the $i$ th market. Consequently, the information share captures the relative amount of information produced for that security in a specific market by examining the relative contribution of each price innovation into the overall common efficient price variance (Hasbrouck, 2004).

The information share for market $i$ will not be uniquely defined when $\Omega$ is not diagonal and a Cholesky factorization is adopted. This methodology leads to an upper and lower bound on the information shares calculated from all possible ordering of the variables in the covariance matrix. ${ }^{7}$ In our analysis we consider the midpoint of the upper- and lower-bound range of information shares as our main price discovery measure. ${ }^{8}$ After computing the median information shares for Treasury and Eurodollar futures, we compare the dynamics and patterns of price discovery across contracts and quantitative easing periods.

\section{$\underline{5.2 \text { Cointegration Tests }}$}

As outlined above, Hasbrouck's (1995) information share approach relies on the presence of a common permanent component for all market prices. In order to adopt this methodology we have

\footnotetext{
${ }^{6}$ The Cholesky factorization allows to consider all possible permutations of the disturbances.

${ }^{7}$ The upper bound for market $i$ is obtained by ordering market $i$ first when permuting $\psi$ and $\Omega$ and therefore placing higher weight on its information share. The lower bound for market $i$ is obtained by ordering it last and therefore minimizing the weight on its information share (Hasbrouck, 1995).

8 The midpoint information shares are a good representation of the relative information shares because the upper- and lower-bound spread is tight, with an average spread across Treasury (Eurodollar) contracts of 0.04 (0.05).
} 
to test for daily cointegration across the four futures contracts for each security. Since we have 4 prices, we need 3 independent cointegrating vectors to correctly compute information shares (Huang, 2002). We adopt the Johansen (1988) cointegration test to identify the days having the required 3 cointegrating vectors. There are two main cointegration tests: trace test and maximum eigenvalue tests. The trace statistics tests the null hypothesis that the number of independent cointegrating vectors is less than or equal to $m$ against the alternative hypothesis that the number of independent cointegrating vectors is greater than $m$. The maximum eigenvalue statistics instead tests the null hypothesis that the number of independent cointegrating vectors is indeed $m$ against the alternative hypothesis that the number of independent cointegrating vectors is $(m+1)$.

The hypotheses of cointegration rank are tested sequentially using Johansen's (1988) cointegration trace test and we discard any days where the hypothesis of a rank of cointegration less than 3 cannot be rejected. Days with either 1, 2 or no independent cointegrating vectors are dropped from the sample. ${ }^{9}$ Including only cointegrated days is the most appropriate way to compute correct information share (Fricke and Menkhoff, 2011). Table reports the cointegration test results. There are a total of 1,607 $(2,108)$ trading days for the Treasury (Eurodollar) futures sample and 40\% (39\%) of the days from our original sample have 3 cointegrating vectors. The final sample for Treasury (Eurodollar) contracts has 647 (817) cointegrated days. As a robustness check, we also run the analysis across the days from the maximum eigenvalue tests; results do not qualitatively change.

[Insert Table 4 about here]

\section{$\underline{5.3 \text { Results }}$}

Figure 3 shows the average daily cumulative impulse response functions for the Treasury (Figure 3a) and Eurodollar (Figure 3b) futures contracts. The impulse response functions show that the

\footnotetext{
${ }_{9}$ The inclusion of only cointegrated days is a widely used practice in price discovery empirical studies. See for example, Hasbrouck (1995), Lien and Shrestha (2009, 2014), and Fricke and Menkhoff (2011).
} 
shortest- and longest-term contract prices for both securities do not converge within the ten-minute window examined; there seems to be a shock that permanently influences the 2- and thirty-year Treasury futures contracts, and the 1- and 9-quarter Eurodollar futures contracts. This is an interesting result given the recognized empirical impact of monetary policy on both short-term and long-term rates (Swanson and Williams, 2014; Gagnon, Raskin, Remache and Sack, 2010; and Krishnamurthy and Vissing-Jorgensen, 2011). The mid-term maturities seem to cause less permanent shocks to the short- and long-term contract prices; after a shock to the mid-term contracts, all prices reach a closer converge range within the ten-minute window examined.

[Insert Figures 3a and 3b about here]

Table 5 reports the midpoint information shares across quantitative easing periods and contract maturities for both underlying Treasury assets (Panel A) and Eurodollar (Panel B) futures contracts. Over the full period analyzed, the contracts with the shortest term to maturity account for the largest portion of information share ranging from $84 \%$ to $72 \%$ for the 2 -year Treasury futures contract and the 1-quarter Eurodollar futures contract, respectively. Results are consistent when we examine the information share across different quantitative easing periods.

[Insert Table 45 about here]

Interestingly, the long-term Eurodollar futures contract with 9 quarters to maturity has a higher information share only during the pre-QE1 period; nonetheless, it still accounts for the smallest portion of price discovery. The higher relative information share observed before the implementation of quantitative easing policy is in line with Gagnon, Raskin, Remache and Sack's (2010) findings concerning the effectiveness of the LSAP program in decreasing long-term rates. The authors find that the two initial FOMC announcements on quantitative easing - in November 2008 and March 2009 - contained the most useful information for investors. At these meetings the Federal Reserve announced a planned future course of actions that investors interpreted as being a 
long-term commitment. In our results, the higher observed information shares for Eurodollar longer-term rates before the QE1 period could be the consequence of this market adjustment.

Figures 4 and 5 show the relative midpoint information shares for all Treasury and Eurodollar futures contracts for the shortest- and longest-term maturities. The shaded regions represent the three quantitative easing periods. The graphs show that there is no significant change in pattern for the information shares of futures contracts across the entire sample period. The short-term maturity remains the most significant contract throughout the distinctive quantitative easing phases.

[Insert Figures 4 and 5 about here]

Through our analysis we are not able to capture the expected patterns of information shares advanced in our second hypothesis. Price discovery does not reflect the effectiveness of unconventional monetary policy as we predicted; nonetheless, it highlights the validity of common price discovery dynamics observed in our results for conventional pre-QE times, where short-term futures contracts impound most of the information.

\section{$\underline{5.4 \text { Robustness Checks }}$}

When interpreting the results it is important to take into account the overall empirical approach used. The price discovery methodology applies only to cointegrated days when the futures contract prices move together; but the cointegration test results clearly shows that sections of the yield curve do not necessarily behave in this matter. The analysis across only cointegrated days could therefore be a limiting factor leading to our unexpected results.

In order to address this concern, we compute information shares across only non-cointegrated days. Table 6 reports the information share midpoints across different maturities for the noncointegrated days in the sample.

[Insert Table 6 about here] 
The information shares levels and dynamics are consistent with the results obtained using only cointegrated days: the short-term maturity contract has the highest information share. We can conclude that discarding the non-cointegrated days does not bias our analysis; the same information share patterns are observed across cointegrated and non-cointegrated days in the dataset. We proceed with our analysis taking into account only cointegrated days.

\section{Part II: Macroeconomic News and Dynamics of Information Shares}

In the second part of our analysis we ask whether information shares are predictable on days of macroeconomic news announcements. New available information changes the informational structure of markets. This implies that investors might incorporate information differently according to the news type and the overall economic circumstances. In specific, we ask if relative information shares across assets and maturities change because of (1) general or specific macroeconomic news announcements, and (2) quantitative easing policy.

In order to test our hypotheses concerning the influence of macroeconomic announcements on price discovery across maturities and quantitative easing periods, we run several model specifications that take into account the release of macroeconomic information along with three of the major contract characteristics - bid-ask spread, volume, and volatility.

\section{$\underline{6.1 \text { Expectations }}$}

Fricke and Mankhoff (2011) and Mizrach and Neely (2008) found rather consistent effects of market state variables and contract characteristics on information shares. We can thus form the following expectations: an increase in spread is expected to decrease relative information shares because including information in markets becomes more costly and because a higher spread could imply lower liquidity; an increase in trading volume increases the effectiveness of market informational structure and thus leads to higher relative information shares; and an increase in 
volatility implies an increase in noise therefore leading to lower relative information shares. Higher volatility could also lead to an increase, rather than a decrease, in information shares if it implies more is not homogeneously available and impounded across markets into prices. Fricke and Menkhoff point out that previous literature results should be considered as being neither universal nor absolute stylized facts.

Concerning the effect of macroeconomic news on price discovery across maturities and quantitative easing periods, we expect the days of announcements to be most critical in driving information shares, especially if they occur during periods of quantitative easing. Such finding would imply that quantitative easing was one of the drivers of price discovery during periods of unconventional monetary policy. Gagnon, Raskin, Remache and Sack (2010) in fact find that unconventional monetary policy was able to significantly decrease long-term rates only during macroeconomic announcement days, while average long-term rates during non-announcement days are found to increase. Information could have been included differently into prices according to quantitative easing periods.

We also expect specific announcements to have a different impact across maturities of Eurodollar futures contracts and underlying Treasury bonds: for example, announcements by the Federal Open Market Committee and news concerning monetary policy should have a significant impact on longer-term relative information shares due to the critical importance of new information during unconventional times.

\subsection{Regression Analysis and Results}

First, we examine the impact of QE-related macroeconomic announcement days and of contract characteristics (Models 1, 2, 3); second, we investigate whether specific news announcements have a significant influence of information shares (Models 4, 5, 6); finally, we test if the effect of these specific news announcements vary across quantitative easing policy periods (Model 7). 
We start by examining the significance of QE-related macroeconomic news on price discovery by running the following three model specifications:

$\underline{\text { Model } 1}$

$$
\ln \left(\frac{I S_{i, t}}{1-I S_{i, t}}\right)=c+b_{1} \text { QENewsDay }_{t}+b_{2} \text { Spread }_{i, t}+b_{3} \text { Volume }_{i, t}+b_{4} \text { Volatility }_{i, t}+\epsilon_{t}
$$

$\underline{\text { Model } 2}$

$$
\ln \left(\frac{I S_{i, t}}{1-I S_{i, t}}\right)=c+b_{1} \text { Spread }_{i, t}+b_{2} \text { Volume }_{i, t}+b_{3} \text { Volatility }_{i, t}+\epsilon_{t}
$$

$\underline{\text { Model } 3}$

$$
\ln \left(\frac{I S_{i, t}}{1-I S_{i, t}}\right)=c+b_{1} \text { QEPeriod }_{t}+b_{2} \text { Spread }_{i, t}+b_{3} \text { Volume }_{i, t}+b_{4} \text { Volatility }_{i, t}+\epsilon_{t}
$$

where $i$ refers to either the Treasury or Eurodollar log-transformed maturity-specific information share. Following Mizrach and Neely (2008) and Fricke and Mekhoff (2010), we choose the logarithmic transformation of variables to account for distributional bias and to allow for an easier interpretation of results. QE NewsDayt is a dummy variable equal to 1 if day $t$ corresponds to a day when the FOMC or the Chairman of the Federal Reserve Bank announced (i) specific amounts of Treasury bonds or mortgage-backed securities to be purchased or sold, or (ii) actions to be taken

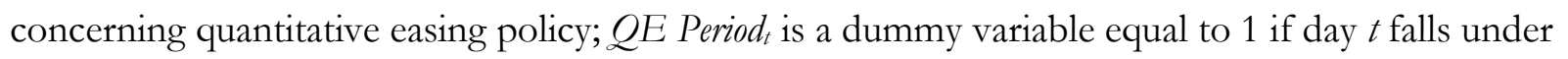
QE1, QE2, or QE3 period and it includes a larger number of announcement days when compared to QE-specific news announcement days. We control for the following contract characteristics: the daily share of spread (Spread) computed as a proportion, where the daily average of price reversals of each maturity contract is divided by the sum over all four contract maturities; the daily share of volume traded (Volume) computed as the contract specific daily number of trades divided by the sum of all trades for the four contract maturities; the daily share of the realized volatility (and Volatility) estimated as the square root of the sum of squared five-minute returns of each contract maturity divided by the sum of realized volatilities of the four contract maturities. 
Table 7, Panel A reports the results for Model 1 and answers the question of whether specific QE-related news announcements affect price discovery along the yield curve. Results indicate that being on a day of QE-specific news release significantly impact the relative information shares of only the contracts on the Treasury bonds having the longest maturity and the shortest Eurodollar futures contracts. The effect, however, is opposite: the information share for long-term Treasury bond futures contracts is positively affected, while Eurodollar futures relative information share decreases. This might be explained by investors changing markets due to the relevant QE-related news announced. As expected, the R-square for this model is very low; there is the need to control for additional factors.

\section{[Insert Table 7 about here]}

In Panel B we control only for three major contract characteristics: spread, volume traded, and realized volatility. Spread is highly significant and with the expected negative sign for the longest and shortest maturity of Treasury futures contracts and for the 1 and 3 quarters Eurodollar futures contracts. A one percent increase in 2 years (30 years) Treasury futures spread will lead to a decrease of about 2 basis points ( 3 basis points) in its information share, while a one percent increase in the spread of the 3 quarters Eurodollar futures contract will decrease the information share by about 2 basis points. The information shares for the 5 and 9 quarters Eurodollar futures contracts are instead positively affected, with an increase of about 1 basis point. The opposite effect on Eurodollar and Treasuries might be caused by investors switching markets.

Volatility exhibits both signs across securities, matching our expectations of a mixed effect from a higher realized volatility. Volume, on the other hand, negatively impacts the information shares of Treasury futures and the shortest and longest maturity contracts of Eurodollar futures. According to Campbell and Hendry (2007), this result can be explained by a worsening of the speed in price discovery due to the higher share of trading volume and more noise being included in the overall 
market. The effect of spread, volume, and volatility are not perfectly in line with the results from previous literature, they are however consistent throughout our analysis. Overall, Panel B shows that the short-term contracts -2 years and 1 quarter - exhibit the highest explanatory power, followed by the long-term contracts -30 years and 9 quarters.

Through Model 3 in Panel $\mathrm{C}$ we reveal that being in a period of quantitative easing has a significant effect on the relative information shares, especially for what concerns the shortest maturity contracts. Information shares for the 2 years Treasury future contract decrease while both shortest term Eurodollar contracts - 1 and 3 quarters - increase during periods of quantitative easing. The negative coefficient on the QE Period dummy matches our expectations that during a period of unconventional monetary policy the information share for the short-term Treasury futures contract decreases. In this case, shifting to a day when quantitative easing is into effect causes a negative impact on the information share of short-term Treasury futures contracts of about $17 \%$. On the other hand, the short-term information share of Eurodollar futures is positively affected despite the unconventional period, experiencing an average positive impact to the information shares of 1 and 3 quarters Eurodollar futures contracts when transitioning to a period of quantitative easing policy.

After analyzing a day of general macroeconomic news release, we investigate whether a specific news announcement has a significant impact on the price discovery of Treasury futures. ${ }^{10}$ We thus run the following three additional model specifications:

$\underline{\text { Model } 4}$

$$
\ln \left(\frac{I S_{i, t}}{1-I S_{i, t}}\right)=c+b_{1} N \text { ewsType } e_{t}+\epsilon_{t}
$$

\footnotetext{
10 We conduct the same analysis for Eurodollar futures contracts. Given the results are consistent across
} both securities and to minimize the length of the paper, we omit the results for Eurodollar futures. 
$\underline{\text { Model } 5}$

$$
\ln \left(\frac{I S_{i, t}}{1-I S_{i, t}}\right)=c+b_{1} \text { NewsType }_{t}+b_{2} \text { Spread }_{i, t}+b_{3} \text { Volume }_{i, t}+b_{4} \text { Volatility }_{i, t}+\epsilon_{t}
$$

$\underline{\text { Model } 6}$

$$
\begin{gathered}
\ln \left(\frac{I S_{i, t}}{1-I S_{i, t}}\right)=c+\sum_{j=1}^{7} b_{j} \text { AnnouncementType }_{j, t}+b_{8} \text { Spread }_{i, t}+b_{9} \text { Volume }_{i, t}+ \\
b_{10} \text { Volatility }_{i, t}+\epsilon_{t}
\end{gathered}
$$

where $i$ refers to the Treasury log-transformed maturity-specific information share, News Typet is a dummy variable equal to 1 if the macroeconomic announcement on day $t$ is either one of the seven announcements analyzed singularly, and $j$ refers to the a specific news announcement. The seven AnnouncementType variables are the following: FOMC Announcements, FOMC Meetings, PPI, CPI, Jobless Claims, ISM Manufacturing Index, and GDP.

In Panels $\mathrm{A}$ and $\mathrm{B}$ of Table 7 we capture the effect of being in a day when at least one of the seven announcements analyzed is released. Panel A shows that days of specific news announcements do influence the information shares; the effect is negative for the short-term contracts, but positive for the long-term contracts. This result is in line with our expectations that information shares should increase for long-term contracts following macroeconomic and policy announcements during a period of unconventional monetary policy. In this case, going from a non-announcement day to an announcement-day causes the short-term contract information share to decrease, while the longterm contract information share increases. However, results in Panel B show that the specific news day effect found in Panel A disappears after controlling for volume, spread, and volatility. The effects of the contract characteristics are in line with the results from our previous models.

$$
\text { [Insert Table } 7 \text { about here] }
$$


In order to truly test our hypotheses we believe there is the need to consider the effect of each announcement separately. Panel $\mathrm{C}$ reports the effect of each specific macroeconomic announcements. Contrary to our expectations but in line with previous literature and results, overall macroeconomic news does not significantly drive or explain relative information shares. However, specific news such as the FOMC and the Jobless Claims announcements have an impact on price discovery. Confirming our expectations, the day of FOMC statements has a negative impact on the 2 years contract information share, while it has a positive effect on the price discovery in the 30 years Treasury futures market. There seems to be a shift in price discovery patters in favor of longer maturity contracts during a day of FOMC statements. The same pattern can be observed for days of initial unemployment claims announcements (Jobless Claims) having a negative (positive) impact on information shares of short-term (long-term) Treasury futures contracts, but we find no other significant macroeconomic announcement. The statistically insignificant daily impact of specific macroeconomic announcements found in Panel C might reflect Balduzzi, Elton, and Green (2001) findings that most economic news is included in government bond prices in the one-minute time frame following the announcement.

Swanson and Williams (2014) found that the beginning of unconventional monetary policy was able to influence long-term rates and it contained the most relevant information for investors. It is possible that the effect of specific macroeconomic news varies according to the period of unconventional policy when the release of information occurs. Consequently, we might expect the announcements to have a different effect on information shares according to the period in which they occur. We thus run the following model on Treasury futures information shares to examine the impact of each of the seven specific announcements across quantitative easing periods: 
$\underline{\text { Model } 7}$

$$
\begin{gathered}
\ln \left(\frac{I S_{i, t}^{q}}{1-I S_{i, t}^{q}}\right)=c+\sum_{j=1}^{7} b_{j}^{q} \text { AnnouncementType }_{j, t}+b_{8}^{q} \text { Spread }_{i, t}+b_{9}^{q} \text { Volume }_{i, t}+ \\
b_{10}^{q} \text { Volatility }_{i, t}+\epsilon_{t}
\end{gathered}
$$

where $i$ refers to Treasury log-transformed maturity-specific information share, $j$ refers to the a specific news announcement, and $q=\{1,2,3,4,5\}$ captures each unconventional monetary policy period: QE1, pre-QE2, QE2, pre-QE3, QE3.

Table 8 reports the results. Even though most of the specific macroeconomic announcements have no significant effect on the price discovery, we can see that across quantitative easing periods being in a day of FOMC announcement matters the most during either the first round or the last round of quantitative easing, QE1 or QE3. The result is partly in line with Swanson and Williams (2014) findings. Interestingly, the relative information share of the contracts for the shortest and longest term underlying securities is significantly affected at the end of the unconventional monetary policy period, QE3. However, the effect is opposite: transitioning to a day of FOMC statements has a negative impact on the information share for the short-term contract, while it has a positive impact of about six-fold on the information share for the long-term contract. The futures contract on the 5 year Treasury is instead affected during the beginning of the quantitative easing periods, QE1 and Pre-QE2.

\section{[Insert Table 8 about here]}

The non-farm payroll announcement is also known as the king of announcements (Andersen and Bollerslev, 1998). However, our Treasury futures dataset of cointegrated days does not include any day when such announcement occurs. For this reason, we run the same model (Model 6) for Eurodollar futures and report the results in Table 9.

[Insert Table 9 about here] 
Non-farm payroll is highly significant for the shortest and longest maturity contract. However, being on a day of such announcement has a negative impact on the information share of the 1 quarter Eurodollar futures contract, and a positive impact on the information shares of other maturity contracts. The qualitative impact of a transition to a day of FOMC statements is in line with the results observed for information shares of Treasury futures contracts.

\section{Summary and concluding remarks}

In this paper we examined the impact of unconventional monetary policy on price discovery along the yield curve. The paper is a contribution to the price discovery and macro-financial linkages literatures because, to the best of our knowledge, it is the first study analyzing relative information shares across different sections of the yield curve before, during and after the recent financial crisis. The questions addressed reveal important implications for the understanding of monetary policy effects on price discovery through the investor's expectations channel.

Our analysis brings to light unexpected results underlying unconventional monetary policy: the

long-term contracts do not have higher relative information shares during periods of unconventional monetary policy despite the effect of quantitative easing on longer-term rates found in earlier studies. Because of the different effects of unconventional monetary policy found in the literature across days of announcements and non-announcements days, we believed it necessary to examine the impact of news releases on price discovery across quantitative easing periods. Our results show that besides FOMC announcements, initial jobless claims, and non-farm payroll news, no other specific news announcement is significant. Lastly, for the intermediate maturity contracts the first round of quantitative easing seems to have the impact outlined in Swanson and Williams (2014) where the beginning of QE announcements have significant effects. The remaining contract 
maturities are mostly affected by FOMC announcements during the end of unconventional monetary policy.

In summary, our study suggests that during QE periods the short end of the yield curve still moves first, followed by the medium and long-term rates. The findings are surprising given previous evidence on the impact of monetary policy changes and announcements on markets. Specific macroeconomic news does not seem to matter significantly, but contract characteristics seem to be the major factors driving price discovery dynamics. We can conclude that unconventional monetary policy did not have disruptive effects in a price discovery setting and quantitative easing is not a significant driver influencing price discovery along the yield curve.

We advance an alternative explanation related to the macro-finance term structure literature: unconventional monetary policy was effective at influencing expectations and longer-term rates, but futures prices and interest rates contained a time-varying risk premium component that went beyond the role of expectations as drivers of long-term rates. The additional risk might be the main driver of our price discovery results given it is strictly related to the underlying interest rates and to the implied term premium. The risk premium component therefore does not seem to be constant over time and it increases the wedge between true prices and expectations. One can argue that, due to the zero lower bound constraint of short-term interest rates, any price changes in the short-term Eurodollar maturity should be due to dynamics of the risk premium.

There are in fact additional factors that come into play in determining the term structure of interest rates, the overall yield curve, and the level and composition of risk faced by investors. Cochrane and Piazzesi (2005) develop an empirical measure to capture the bond risk premium by considering forward iteration of both the one-year expected excess returns and the current one-year interest rate; Ludvigson and $\mathrm{Ng}$ (2009) investigate the relationship between macroeconomic variables and risk premia, and find that there are real and inflation factors providing new information 
useful for expectations on future interest rate. Furthermore, Cochrane (2007) argues that there is the need to decompose the yield curve and capture the effects from expectations and those from timevarying risk premia.

By adopting a price discovery analysis, our goal was to capture changes in expectations of future short-term rates. However, findings from the term-structure literature suggest that we might actually be capturing a change in risk premia underling interest rates and unconventional monetary policy. If this is the case, and if the yield risk premium is in fact not constant, it must be that the expectation hypothesis does not hold.

The question then becomes, do long-term rates reflect the investor expectations, do they capture an underlying change in the overall risk premia, or both? ${ }^{11}$ Our results seem to point in favor of the presence of underlying time-varying risk premia compoenents. In order to fully answer this question, however, it is necessary to decompose the changes in expectations and those of time-varying risk premium separately. This can be an avenue for future research and an opportunity to expand the macro-finance term structure literature.

11 This concept has been addressed in past literature, and can be summarized in Federal Reserve Governor Donald Kohn's (2005) speech: “to what extent are long-term interest rates low because investors expect short-term rates to be low in the future... and to what extent do low long rates reflect narrow term premiums?" https://www.federalreserve.gov/boarddocs/speeches/2005/20050721/ 


\section{References}

Andersen, T. G., Bollerslev, T., 1998. Deutsche Mark-Dollar volatility: intraday activity patterns, macroeconomic announcements, and longer run dependencies. The Journal of Finance, 53, $219-65$.

Andersen, T. G., Bollerslev, T., Diebold, F. X., and Vega, C., 2003. Micro effects of macro announcements: real-time price discovery in foreign exchange, American Economic Review, 93, $38-62$.

Basistha, A., Kurov, A., 2015. The Impact of Monetary Policy Surprises on Energy Prices, Journal of Futures Markets, 35, 87-103.

Balduzzi, P., Elton, E. J., Green, T. C., 2001. Economic news and bond prices: evidence from the U.S. Treasury market, The Journal of Financial and Quantitative Analysis, Vol. 36, 4, 523-543.

Balduzzi, P., Moneta, F., 2016. Economic risk premia and the fixed income markets: the intra-day evidence. Unpublished Working Paper.

Bernanke, B. S., Kuttner, K. N., 2005. What explains the stock market's reaction to Federal Reserve policy? Journal of Finance, 60, 1221-1257.

Burger, A., Lang, R., Rasche, R., 1977. The Treasury bill futures market and market expectation of interest rates, Federal Reserve Bank of St. Louis Review, June 1977, 2-9.

Boyd, J. H., Hu, J., Jagannathan, R., 2005. Stock market's reaction to unemployment news, Journal of Finance, 60, 649-672

Campbell, B., Hendry, S., 2007. Price discovery in Canadian and U.S. 10-year government bond markets. Bank of Canada, Unpublished Working Paper.

Chen, Y., Gau, Y., 2010. News announcements and price discovery in foreign exchange spot and future markets, Journal of Banking and Finance, 34, 1628-1636.

Chernenko, S. V., Schwarz, K. B., Wright, J. H., 2004. The information content of forward and futures prices: market expectations and the price of risk, Unpublished Working Paper.

Cochrane, J. H., Piazzesi, M., 2005. Bond risk premia. American Economic Review, Vol. 94, 1, 138-160.

Cochrane, J. H., 2007. Commentary, Federal Reserve Bank of St. Louis Review, July/August 2007, 271-282.

Feroli, M., Kashyap, A. K., Schoenholtz, K., Shin, H. S., 2014. Market tantrums and monetary policy. Unpublished Working Paper.

Ferrero, G., Nobili, A., 2009. Futures contract rates as monetary policy forecasts. International Journal of Central Banking, 5 (2), 109-145. 
Fleming, M. J., Remolona, E. M., 1999. Price formation and liquidity in the U.S. Treasury market: The response to public information, Journal of Finance, 54, 1901-1915.

Fricke, C., Menkhoff, L., 2011. Does the "bund" dominate price discovery in Euro bond futures? Examining information shares, Journal of Banking and Finance, 35, 10577-1072.

Gagnon, J. E., Raskin, M., Remache, J., Sack, B., 2010. Large-scale asset purchases by the Federal Reserve: did they work? Unpublished Working Paper.

Gürkaynak, R. S., Sack, B., Swanson, E. 2005. Do actions speak louder than words? The response of asset prices to monetary policy actions and statements. International Journal of Central Banking, 1, 55-93.

Gürkaynak, R. S., Sack, B., Swanson, E. T., 2007. The U.S. Treasury Yield Curve: 1961 to the Present. Journal of Monetary Economics, 54 (8), 2291-2304.

Hasbrouk, J., 1995. One security, many markets: determining the contributions to price discovery. The Journal of Finance, 50 (4), 1175-1199.

Hasbrouk, J., 2002. Price Discovery Analysis in SAS Version 1.0. Unpublished Working Paper.

Hasbrouk, J., 2004. Empirical market microstructure: economic and statistical perspectives on the dynamics of trades in security markets. Unpublished Lecture Notes.

Huang, R., 2002. The quality of ECN and Nasdaq market maker quotes, The Journal of Finance, Vol. LVII, No. 3, 1285-1319.

Johansen, S., 1988. Statistical analysis of cointegration vectors, Journal of Economic Dynamics and Control, Vol 12, 231-254.

Jian, G. J., Lo, I., 2014. Private information flow and price discovery in the U.S. treasury market, Journal of Banking and Finance, 47, 118-133.

Kohn, D. L., 2005. Monetary policy perspectives on risk premiums in financial markets. Remarks by Governor Donald L. Kohn at the financial market risk premiums conference, Federal Reserve Board, Washington, D.C., July 21, 2005. Retrieved from https://www.federalreserve.gov/boarddocs/speeches/2005/20050721/

Krishnamurthy, A., Vissing-Jorgensen, A., 2011. The effects of quantitative easing on interest rates: channels and implications for policy, Brookings Papers on Economic Activity, Fall $2011,215-287$.

Lien, D., Shrestha, K., 2009. A new information share measure, The Journal of Futures Markets, Vol. 29, No. 4, 377-395.

Lien, D., Shrestha, K., 2014. Price discovery in interrelated markets, The Journal of Futures Markets, Vol. 34, No. 3, 203-2019. 
Ludvigson, S. C, Ng, S., 2009. Macro Factors in Bond Risk Premia. The Review of Financial Studies, Vol. 22, 12, 5027-5067.

Mizrach, B., Neely, C. J., 2008. Information shares in the US Treasury market, Journal of Banking and Finance, 32, 1221-1233.

Rudebusch, G. D., Wu, T., 2008. A macro-finance model of the term structure, monetary policy and the economy. The Economic Journal, 118, 906-926.

Swanson, E. T., Williams, J. C., 2014. Measuring the effect of the zero lower bound on medium- and longer-term interest rates, American Economic Review, 104, 10, 3154-3185. 
Table 1

Descriptive statistics.

This table reports the summary statistics for the Treasury rate at constant maturity and the implied LIBOR rate from Eurodollar futures. The Treasury data is gathered by the Federal Reserve Bank of St. Louis database, while the implied LIBOR rate is computed as 100 minus the Eurodollar futures price.

\begin{tabular}{lccccc}
\hline \multicolumn{7}{l}{ Panel A. Treasury Constant Maturity Rate } & & & \\
\hline Expiration & Mean & Median & Std Dev & Minimum & Maximum \\
\hline 2 years & 0.73 & 0.56 & 0.58 & 0.21 & 2.77 \\
5 years & 1.69 & 1.60 & 0.69 & 0.62 & 3.49 \\
10 years & 2.68 & 2.73 & 0.71 & 1.53 & 4.10 \\
30 years & 3.65 & 3.65 & 0.66 & 2.46 & 4.69 \\
\hline Panel B. Implied LIBOR Rate & & & & \\
\hline Expiration & Mean & Median & Std Dev & Minimum & Maximum \\
\hline 1 quarter & 1.25 & 0.61 & 1.13 & 0.22 & 4.51 \\
3 quarters & 1.33 & 0.91 & 0.99 & 0.25 & 4.40 \\
5 quarters & 1.55 & 1.28 & 0.98 & 0.34 & 4.44 \\
9 quarters & 1.96 & 1.78 & 0.97 & 0.50 & 5.32 \\
\hline
\end{tabular}




\section{Table 2}

U.S. Macroeconomic Announcements.

The following table reports the seven macroeconomic news we considered in our regression analysis when investigating the impact of specific announcements on the dynamics of Treasury futures information shares. There are a total of 154 announcement news types reported in Bloomberg's Economic Calendar database. FRB: Federal Reserve Board; BLS: Bureau of Labor Statistics; BEA: Bureau of Economic Analysis; USDOL: U.S. Department of Labor; ISM: Institute for Supply Management.

\begin{tabular}{lccc}
\hline Announcement & Agency & Frequency & Observations \\
\hline FOMC Announcements & FRB & Eight times a year (min.) & 32 \\
FOMC Meetings & FRB & Eight times a year & 27 \\
Change CPI & BLS & Monthly & 24 \\
Change in PPI & BLS & Monthly & 28 \\
GDP & BEA & Quarterly & 22 \\
Jobless Claims & USDOL & Weekly & 151 \\
ISM Mfg Index & ISM & Monthly & 29 \\
\multicolumn{4}{l}{} \\
Days with at least one news announcement of interest & $313(48 \%)$ \\
Days with at least one macroeconomic announcement & $605(94 \%)$ \\
\hline
\end{tabular}




\section{Table 3}

Days of QE purchases/sales announcements

The following table reports the days in the Treasury and Eurodollar futures contracts samples coinciding with days of QE-related news announcements. The specific actions announced concerning the purchase or sale of security quantitative easing measures are also specified.

\begin{tabular}{lllll}
\hline Period & Day & Event & Action & Sample \\
\hline QE 1 & Dec. 16, 2008 & FOMC Statement & & Eurodollar \\
QE 1 & Dec. 30, 2008 & FOMC Statement & & Treasury \\
QE 1 & Feb. 23, 2009 & FOMC Statement & & Treasury \\
QE 1 & Sept. 23, 2009 & FOMC Statement & & Treasury \\
QE 1 & Nov. 4, 2009 & FOMC Statement & & Treasury \\
QE 2 & Nov. 3, 2010 & QE Statement & \$600 billion T-bonds & Treasury \\
QE 2 & June 20, 2012 & QE Statement & \$267 billion T-bonds & Treasury and Eurodollar \\
QE 3 & Aug. 22, 2012 & QE Statement & & Treasury \\
QE 3 & Sept. 13, 2012 & QE Statement & $\$ 40$ billion per month, MBS & Eurodollar \\
QE 3 & Nov. 2, 2012 & FOMC Statement & & Eurodollar \\
QE 3 & Dec. 12, 2012 & QE Statement & \$45 billion per month, MBS & Treasury \\
TAPER & May 1, 2013 & QE Statement & Hint at reducing purchases & Eurodollar \\
TAPER & May 22, 2013 & QE Statement & Hint at reducing purchases & Treasury \\
TAPER & June 19,2013 & FOMC Statement & & Treasury \\
TAPER & Jan 29,2014 & FOMC Statement & & Eurodollar \\
END & June 18, 2014 & QE Statement & Might end QE3 & Treasury and Eurodollar \\
END & Oct. 29, 2014 & QE Statement & End of QE & Treasury \\
\hline
\end{tabular}




\section{Table 4}

Cointegration tests.

This table shows the total number of days and the overall percentage of days having 3 cointegrating vectors according to the trace and maximum eigenvaule Johansen (1988) tests of cointegration. The Treasury futures contracts full sample has 1607 total days; the Eurodollar futures contracts full sample has 2108 total days.

\begin{tabular}{lcc}
\hline Panel A. Treasury futures contracts. & & \\
\hline Test & Days Cointegrated & Percentage of days cointegrated \\
Trace & 647 & $40 \%$ \\
Maximum eigenvalue & 1018 & $63 \%$ \\
\hline \multicolumn{2}{l}{ Panel B. Eurodollar futures contracts. } & \\
\hline Test & Days Cointegrated & Percentage of days cointegrated \\
Trace & 817 & $39 \%$ \\
Maximum eigenvalue & 863 & $41 \%$ \\
\hline
\end{tabular}




\section{Table 5}

Midpoint information shares.

This table reports the average midpoint information shares for Treasury and Eurodollar futures contracts across maturities for both the full sample periods and quantitative easing periods. The quantitative easing ranges are the following:

Pre QE1 Before November 25th 2008

QE1 November 25th 2008 to March $31^{\text {st }} 2010$

Post QE1 April 1st 2010 to November 2 ${ }^{\text {nd }}, 2010$

QE2 November 3 $3^{\text {rd }}, 2010$ to June 30th 2011

Post QE2 July 1 ${ }^{\text {st }}, 2011$ to September 12 $2^{\text {th }}, 2012$

QE3 September 13th 2012 to October 29 ${ }^{\text {th }}, 2014$ (QE3 and QE3 tapered periods)

Post QE3 After October 30 ${ }^{\text {th }}, 2014$

\begin{tabular}{|c|c|c|c|c|c|c|c|c|}
\hline \multicolumn{9}{|c|}{ Panel A. Treasury futures contracts. } \\
\hline & \multicolumn{8}{|c|}{ Across Quantitative Easing Periods } \\
\hline & Full Period & Pre QE1 & QE1 & Post QE1 & QE2 & Post QE2 & QE3 & Post QE3 \\
\hline 2 years & 0.84 & 0.68 & 0.82 & 0.85 & 0.87 & 0.90 & 0.87 & 0.82 \\
\hline 5 years & 0.13 & 0.21 & 0.14 & 0.13 & 0.11 & 0.09 & 0.10 & 0.15 \\
\hline 10 years & 0.02 & 0.09 & 0.03 & 0.02 & 0.02 & 0.01 & 0.01 & 0.02 \\
\hline 30 years & 0.02 & 0.06 & 0.02 & 0.01 & 0.01 & 0.01 & 0.01 & 0.02 \\
\hline Obs. & 647 & 58 & 114 & 67 & 69 & 100 & 155 & 84 \\
\hline \multicolumn{9}{|c|}{ Panel B. Eurodollar futures contracts. } \\
\hline & \multicolumn{8}{|c|}{ Across Quantitative Easing Periods } \\
\hline & Full Period & Pre QE1 & QE1 & Post QE1 & QE2 & Post QE2 & QE3 & Post QE3 \\
\hline 1 quarter & 0.72 & 0.39 & 0.61 & 0.73 & 0.76 & 0.79 & 0.78 & 0.71 \\
\hline 3 quarters & 0.07 & 0.17 & 0.10 & 0.04 & 0.04 & 0.05 & 0.05 & 0.07 \\
\hline 5 quarters & 0.16 & 0.33 & 0.23 & 0.17 & 0.17 & 0.10 & 0.12 & 0.19 \\
\hline 9 quarters & 0.06 & 0.13 & 0.07 & 0.06 & 0.04 & 0.06 & 0.05 & 0.04 \\
\hline Obs. & 817 & 76 & 83 & 30 & 26 & 150 & 314 & 138 \\
\hline
\end{tabular}




\section{Table 6}

Midpoint information shares across non-cointegrated days.

This table reports the average midpoint information shares across only non-cointegrated days for Treasury and Eurodollar futures contracts. Information shares are computed across maturities for both the full sample periods and quantitative easing periods. The quantitative easing ranges are the following:

Pre QE1 Before November 25 $5^{\text {th }}, 2008$

QE1 November $25^{\text {th }}, 2008$ to March $31^{\text {st }} 2010$

Post QE1 April $1^{\text {st }} 2010$ to November $2^{\text {nd }}, 2010$

QE2 November $3^{\text {rd }}, 2010$ to June $30^{\text {th }}, 2011$

Post QE2 July $1^{\text {st }}, 2011$ to September $12^{\text {th }}, 2012$

QE3 September 13 ${ }^{\text {th }}, 2012$ to October 29 $9^{\text {th }}, 2014$ (QE3 and QE3 tapered periods)

Post QE3 After October 30 ${ }^{\text {th }}, 2014$

\begin{tabular}{|c|c|c|c|c|c|c|c|c|}
\hline & \multicolumn{8}{|c|}{ Across Quantitative Easing Periods } \\
\hline & Full Period & Pre QE1 & QE1 & Post QE1 & QE2 & Post QE2 & QE3 & Post QE3 \\
\hline 2 years & 0.85 & 0.73 & 0.83 & 0.88 & 0.88 & 0.89 & 0.87 & 0.84 \\
\hline 5 years & 0.12 & 0.18 & 0.12 & 0.09 & 0.10 & 0.09 & 0.12 & 0.13 \\
\hline 10 years & 0.02 & 0.08 & 0.03 & 0.02 & 0.02 & 0.01 & 0.01 & 0.01 \\
\hline 30 years & 0.02 & 0.05 & 0.03 & 0.01 & 0.01 & 0.01 & 0.01 & 0.02 \\
\hline Obs. & 947 & 113 & 161 & 59 & 69 & 152 & 273 & 120 \\
\hline \multicolumn{9}{|c|}{ Panel B. Eurodollar futures contracts across non-cointegrated days. } \\
\hline & \multicolumn{8}{|c|}{ Across Quantitative Easing Periods } \\
\hline & Full Period & Pre QE1 & QE1 & Post QE1 & QE2 & Post QE2 & QE3 & Post QE3 \\
\hline 1 quarter & 0.79 & 0.85 & 0.87 & 0.78 & 0.78 & 0.74 & 0.68 & 0.81 \\
\hline 3 quarters & 0.16 & 0.10 & 0.11 & 0.17 & 0.19 & 0.18 & 0.12 & 0.15 \\
\hline 5 quarters & 0.05 & 0.04 & 0.02 & 0.04 & 0.03 & 0.08 & 0.09 & 0.04 \\
\hline 9 quarters & 0.01 & 0.02 & 0.01 & 0.01 & 0.01 & 0.01 & 0.01 & 0.01 \\
\hline Obs. & 1,283 & 160 & 265 & 124 & 144 & 162 & 235 & 193 \\
\hline
\end{tabular}




\section{Table 7}

U.S. Macroeconomic News and Information Shares

The table reports the regression analysis across Treasury and Eurodollar futures contracts maturities.

QENewsDayt is a dummy variable equal to 1 if day t corresponds to a day when the FOMC or the Chairman of the Federal Reserve Bank announced specific amounts of Treasury bond purchases or actions to be taken concerning quantitative easing measure; $S_{p r e a d_{t}}$ represents the daily share of spread computed as the daily average of price reversals of each maturity contract divided by the sum over all four contract maturities; Volumet represents the daily share of volume traded computed as the contract specific daily number of trades divided by the sum of all trades for the four contract maturities; Volatility $y_{t}$ represents the daily share of the realized volatility estimated as the square root of the sum of squared five-minute returns of each contract maturity divided by the sum of realized volatilities of the four contract maturities; $Q E$ Period $t$ is a dummy variable equal to 1 if day $t$ falls under QE1, QE2, or QE3 period; The dependent variable is the log-transformed maturityspecific information share.

\begin{tabular}{|c|c|c|c|c|c|c|c|c|}
\hline \multicolumn{9}{|c|}{ Panel A } \\
\hline & \multicolumn{4}{|c|}{ Treasury Futures Information Shares } & \multicolumn{4}{|c|}{ Eurodollar Futures Information Shares } \\
\hline & $2 \mathrm{yrs}$ & $5 \mathrm{yrs}$ & $10 \mathrm{yrs}$ & 30 yrs & $1 \mathrm{qrtr}$ & $3 \mathrm{qrtr}$ & $5 \mathrm{qrtr}$ & 9 qrtr \\
\hline Constant & $\begin{array}{l}-4.400^{* * *} \\
(0.58)\end{array}$ & $\begin{array}{l}-1.182 \\
(0.68)\end{array}$ & $\begin{array}{l}0.993 \\
(1.97)\end{array}$ & $\begin{array}{l}-10.107 * * * \\
(1.07)\end{array}$ & $\begin{array}{l}-0.321 \\
(0.32)\end{array}$ & $\begin{array}{l}-6.019 * * * \\
(0.73)\end{array}$ & $\begin{array}{l}1.779 * * * \\
(0.62)\end{array}$ & $\begin{array}{l}-5.315^{* * *} \\
(0.63)\end{array}$ \\
\hline QENewsDa & -0.124 & -0.179 & 0.332 & $1.327 * *$ & $-0.712 * *$ & 0.287 & 0.504 & 0.672 \\
\hline$y_{t}$ & $(0.21)$ & $(0.29)$ & $(0.68)$ & $(0.63)$ & $(0.36)$ & $(0.56)$ & $(0.42)$ & $(0.56)$ \\
\hline Spread ${ }_{i, t}$ & $\begin{array}{l}-2.322^{* * *} \\
(0.28)\end{array}$ & $\begin{array}{l}0.687 * * \\
(0.27)\end{array}$ & $\begin{array}{l}3.609 * * * \\
(0.84)\end{array}$ & $\begin{array}{l}-3.427 * * * \\
(0.61)\end{array}$ & $\begin{array}{l}-0.311 * \\
(0.18)\end{array}$ & $\begin{array}{l}-1.513^{* * *} \\
(0.34)\end{array}$ & $\begin{array}{l}1.143^{* * *} \\
(0.30)\end{array}$ & $\begin{array}{l}0.645^{* * * *} \\
(0.22)\end{array}$ \\
\hline Volume $_{\mathrm{i}, \mathrm{t}}$ & $\begin{array}{l}-0.676^{* * *} \\
(0.10)\end{array}$ & $\begin{array}{l}-0.487 \\
(0.35)\end{array}$ & $\begin{array}{l}-1.625 \\
(1.24)\end{array}$ & $\begin{array}{l}-0.595 \\
(0.48)\end{array}$ & $\begin{array}{l}-1.078^{* * *} \\
(0.10)\end{array}$ & $\begin{array}{l}0.191 * \\
(0.10)\end{array}$ & $\begin{array}{l}1.122^{* * *} \\
(0.138)\end{array}$ & $\begin{array}{l}-0.446^{* * *} \\
(0.07)\end{array}$ \\
\hline Volatility i,t & $\begin{array}{l}0.080^{* * *} \\
(0.02)\end{array}$ & $\begin{array}{l}0.094 \\
(0.07)\end{array}$ & $\begin{array}{l}1.310 \\
(1.25)\end{array}$ & $\begin{array}{l}-2.188^{* * *} \\
(0.82)\end{array}$ & $\begin{array}{l}0.262^{* *} \\
(0.12)\end{array}$ & $\begin{array}{l}-0.926^{* * *} \\
(0.34)\end{array}$ & $\begin{array}{l}0.469 \\
(0.29)\end{array}$ & $\begin{array}{l}-1.576^{* * *} \\
(0.30)\end{array}$ \\
\hline R-sq. & 0.20 & 0.02 & 0.09 & 0.19 & 0.14 & 0.04 & 0.09 & 0.17 \\
\hline Obs. & 647 & 647 & 647 & 647 & 817 & 817 & 817 & 817 \\
\hline \multicolumn{9}{|c|}{ Panel B } \\
\hline & \multicolumn{4}{|c|}{ Treasury Futures Information Shares } & \multicolumn{4}{|c|}{ Eurodollar Futures Information Shares } \\
\hline & $2 \mathrm{yrs}$ & 5 yrs & $10 \mathrm{yrs}$ & $30 \mathrm{yrs}$ & $1 \mathrm{qrtr}$ & 3 qrtr & 5 qrtr & 9 qrtr \\
\hline Constant & $\begin{array}{l}-4.409 \text { *** } \\
(0.57)\end{array}$ & $\begin{array}{l}-1.202^{*} \\
(0.68)\end{array}$ & $\begin{array}{l}1.047 \\
(1.97)\end{array}$ & $\begin{array}{l}-9.923^{* * *} \\
(1.07)\end{array}$ & $\begin{array}{l}-0.318 \\
(0.32)\end{array}$ & $\begin{array}{l}-6.045^{* * *} \\
(0.73)\end{array}$ & $\begin{array}{l}1.775^{* *} \\
(0.62)\end{array}$ & $\begin{array}{l}-5.240 * * * \\
(0.62)\end{array}$ \\
\hline Spread $_{i, t}$ & $\begin{array}{l}-2.323^{* * *} \\
(0.28)\end{array}$ & $\begin{array}{l}0.689 * * \\
(0.27)\end{array}$ & $\begin{array}{l}3.598^{* * *} \\
(0.83)\end{array}$ & $\begin{array}{l}-3.399 * * * \\
(0.61)\end{array}$ & $\begin{array}{l}-0.309 * \\
(0.18)\end{array}$ & $\begin{array}{l}-1.526^{* * *} \\
(0.34)\end{array}$ & $\begin{array}{l}1.150^{* * *} \\
(0.30)\end{array}$ & $\begin{array}{l}0.667 * * * \\
(0.22)\end{array}$ \\
\hline Volume $_{\mathrm{i}, \mathrm{t}}$ & $\begin{array}{l}-0.681^{* * *} \\
(0.10)\end{array}$ & $\begin{array}{l}-0.502 \\
(0.35)\end{array}$ & $\begin{array}{l}-1.626 \\
(1.62)\end{array}$ & $\begin{array}{l}-0.515 \\
(0.48)\end{array}$ & $\begin{array}{l}-1.068^{* * *} \\
(0.10)\end{array}$ & $\begin{array}{l}0.190 \\
(0.10)\end{array}$ & $\begin{array}{l}1.115^{* * *} \\
(0.14)\end{array}$ & $\begin{array}{l}-0.442 \\
(0.07)\end{array}$ \\
\hline Volatility $\mathrm{i}, \mathrm{t}$ & $\begin{array}{l}0.080^{* * *} \\
(0.02)\end{array}$ & $\begin{array}{l}0.094 \\
(0.07)\end{array}$ & $\begin{array}{l}1.359 \\
(1.24)\end{array}$ & $\begin{array}{l}-2.208^{* * *} \\
(0.82)\end{array}$ & $\begin{array}{l}0.259^{* *} \\
(0.12)\end{array}$ & $\begin{array}{l}-0.936^{* * *} \\
(0.34)\end{array}$ & $\begin{array}{l}0.462^{* * *} \\
(0.29)\end{array}$ & $\begin{array}{l}-1.559 * * * \\
(0.30)\end{array}$ \\
\hline R-sq. & 0.201 & 0.022 & 0.087 & 0.174 & 0.133 & 0.042 & 0.092 & 0.164 \\
\hline Obs. & 647 & 647 & 647 & 647 & 817 & 817 & 817 & 817 \\
\hline
\end{tabular}


Table 7 , continued

Panel C

\begin{tabular}{|c|c|c|c|c|c|c|c|c|}
\hline & \multicolumn{4}{|c|}{ Treasury Futures Information Shares } & \multicolumn{4}{|c|}{ Eurodollar Futures Information Shares } \\
\hline & $2 \mathrm{yrs}$ & 5 yrs & $10 \mathrm{yrs}$ & $30 \mathrm{yrs}$ & $1 \mathrm{grtr}$ & $3 \mathrm{grtr}$ & $5 \mathrm{qrtr}$ & $9 \mathrm{grtr}$ \\
\hline Constant & $\begin{array}{l}-3.841^{* * *} \\
(0.60)\end{array}$ & $\begin{array}{l}-1.747 \text { ** } \\
(0.83)\end{array}$ & $\begin{array}{l}1.029 \\
(1.97)\end{array}$ & $\begin{array}{l}-9.970^{* * *} \\
(1.12)\end{array}$ & $\begin{array}{l}-0.600^{*} \\
(0.33)\end{array}$ & $\begin{array}{l}-6.280^{* * *} \\
(0.53)\end{array}$ & $\begin{array}{l}1.633^{* * *} \\
(0.63)\end{array}$ & $\begin{array}{l}-5.253 * * * \\
(0.62)\end{array}$ \\
\hline QE Period $t$ & $\begin{array}{l}-0.191 \text { *** } \\
(0.07)\end{array}$ & $\begin{array}{l}0.132 \\
(0.11)\end{array}$ & $\begin{array}{l}0.164 \\
(0.22)\end{array}$ & $\begin{array}{l}-0.033 \\
(0.21)\end{array}$ & $\begin{array}{l}0.253^{* * *} \\
(0.08)\end{array}$ & $\begin{array}{l}0.251^{* *} \\
(0.12)\end{array}$ & $\begin{array}{l}-0.113 \\
(0.09)\end{array}$ & $\begin{array}{l}0.115 \\
(0.14)\end{array}$ \\
\hline Spread $_{\mathrm{i}, \mathrm{t}}$ & $\begin{array}{l}-2.145^{* * *} \\
(0.28)\end{array}$ & $\begin{array}{l}0.616^{* *} \\
(0.28)\end{array}$ & $\begin{array}{l}3.455^{* * * *} \\
(0.86)\end{array}$ & $\begin{array}{l}-3.426^{* * *} \\
(0.64)\end{array}$ & $\begin{array}{l}-0.506^{* * *} \\
(0.19)\end{array}$ & $\begin{array}{l}-1.728^{* * *} \\
(0.36)\end{array}$ & $\begin{array}{l}1.015^{* * *} \\
(0.32)\end{array}$ & $\begin{array}{l}0.732^{* * *} \\
(0.24)\end{array}$ \\
\hline Volume $_{i, t}$ & $\begin{array}{l}-0.650^{* * *} \\
(0.10)\end{array}$ & $\begin{array}{l}-0.700^{*} \\
(0.39)\end{array}$ & $\begin{array}{l}-1.415 \\
(1.29)\end{array}$ & $\begin{array}{l}-0.541 \\
(0.51)\end{array}$ & $\begin{array}{l}-0.975^{* * *} \\
(0.10)\end{array}$ & $\begin{array}{l}0.224 * * \\
(0.11)\end{array}$ & $\begin{array}{l}1.141^{* * *} \\
(0.14)\end{array}$ & $\begin{array}{l}-0.462^{* * *} \\
(0.07)\end{array}$ \\
\hline Volatility i,t & $\begin{array}{l}-0.070^{* * *} \\
(0.02)\end{array}$ & $\begin{array}{l}0.083 \\
(0.07)\end{array}$ & $\begin{array}{l}1.482 \\
(1.25)\end{array}$ & $\begin{array}{l}-2.212^{* * *} \\
(0.82)\end{array}$ & $\begin{array}{l}0.283^{* *} \\
(0.12)\end{array}$ & $\begin{array}{l}-0.861 \text { *** } \\
(0.23)\end{array}$ & $\begin{array}{l}0.431 \\
(0.29)\end{array}$ & $\begin{array}{l}-1.566^{* * *} \\
(0.30)\end{array}$ \\
\hline $\begin{array}{l}\text { R-sq. } \\
\text { Obs. }\end{array}$ & $\begin{array}{l}0.212 \\
647\end{array}$ & $\begin{array}{l}0.026 \\
647\end{array}$ & $\begin{array}{l}0.089 \\
647\end{array}$ & $\begin{array}{l}0.174 \\
647\end{array}$ & $\begin{array}{l}0.145 \\
817\end{array}$ & $\begin{array}{l}0.047 \\
817\end{array}$ & $\begin{array}{l}0.093 \\
817\end{array}$ & $\begin{array}{l}0.165 \\
817\end{array}$ \\
\hline
\end{tabular}




\section{Table 8}

Specific U.S. Macroeconomic Announcements and Information Shares

The table report the regression analysis for log-transformed maturity-specific information shares of Treasury futures contracts (Panels A, B, C). NewsType is a dummy variable equal to 1 if the macroeconomic announcement is either one of the following seven: FOMC statements, FOMC Meetings, PPI, CPI, Jobless Claims, ISM Manufacturing Index, and GDP. Spread $d_{t}$ represents the daily share of spread computed as the daily average of price reversals of each maturity contract divided by the sum over all four contract maturities; Volume $e_{t}$ represents the daily share of volume traded computed as the contract specific daily number of trades divided by the sum of all trades for the four contract maturities; Volatility $y_{t}$ represents the daily share of the realized volatility estimated as the square root of the sum of squared five-minute returns of each contract maturity divided by the sum of realized volatilities of the four contract maturities.

\begin{tabular}{|c|c|c|c|c|}
\hline \multicolumn{5}{|c|}{ Panel A } \\
\hline & \multicolumn{4}{|c|}{ Treasury Futures Information Shares } \\
\hline & 2 yrs & 5 yrs & $10 \mathrm{yrs}$ & $30 \mathrm{yrs}$ \\
\hline \multirow[t]{2}{*}{ Constant } & $1.847 * * *$ & $-2.153 * * *$ & $-2.153 * * *$ & $-4.896^{* * *}$ \\
\hline & $(0.03)$ & $(0.03)$ & $(0.06)$ & $(0.06)$ \\
\hline \multirow[t]{2}{*}{ News'Type $_{t}$} & $-0.210^{*}$ & 0.119 & $0.119^{*}$ & $0.601 * *$ \\
\hline & $(1.12)$ & $(0.13)$ & $(0.24)$ & $(0.24)$ \\
\hline R-sq. & 0.005 & 0.001 & 0.005 & 0.010 \\
\hline Obs. & 647 & 647 & 647 & 647 \\
\hline \multicolumn{5}{|c|}{ Panel B } \\
\hline & \multicolumn{4}{|c|}{ Treasury Futures Information Shares } \\
\hline & 2 yrs & $5 \mathrm{yrs}$ & $10 \mathrm{yrs}$ & $30 \mathrm{yrs}$ \\
\hline \multirow[t]{2}{*}{ Constant } & $-4.362 * * *$ & $-1.174 *$ & 0.769 & $-9.772 * * *$ \\
\hline & $(0.58)$ & $(0.68)$ & $(1.98)$ & $(1.08)$ \\
\hline \multirow{2}{*}{ News'Type $_{t}$} & -0.100 & -0.061 & 0.364 & 0.385 \\
\hline & $(0.11)$ & $(0.15)$ & $(0.32)$ & $(0.30)$ \\
\hline \multirow[t]{2}{*}{ Spread $_{i, t}$} & $-2.310 * * *$ & $0.710^{* * *}$ & $3.459 * * *$ & $-3.261 * * *$ \\
\hline & $(0.28)$ & $(0.27)$ & $(0.84)$ & $(0.62)$ \\
\hline \multirow[t]{2}{*}{ Volume $_{\mathrm{i}, \mathrm{t}}$} & $-0.676^{* * *}$ & -0.517 & -1.739 & -0.465 \\
\hline & $(0.10)$ & $(0.35)$ & $(1.27)$ & $(0.48)$ \\
\hline \multirow[t]{2}{*}{ Volatility i,t } & $0.080^{* * *}$ & 0.095 & 1.368 & $-2.242^{* * *}$ \\
\hline & $(0.02)$ & $(0.07)$ & $(1.24)$ & $(0.82)$ \\
\hline R-sq. & 0.202 & 0.023 & 0.091 & 0.179 \\
\hline Obs. & 647 & 647 & 647 & 647 \\
\hline
\end{tabular}


Table 8, continued

\begin{tabular}{|c|c|c|c|c|}
\hline \multicolumn{5}{|c|}{ Panel C } \\
\hline & \multicolumn{4}{|c|}{ Treasury Futures Information Shares } \\
\hline & 2 yrs & 5 yrs & $10 \mathrm{yrs}$ & $30 \mathrm{yrs}$ \\
\hline \multirow[t]{2}{*}{ Constant } & $-4.458^{* * *}$ & $-1.373^{* *}$ & 0.829 & $-9.807 * * *$ \\
\hline & $(0.57)$ & $(0.69)$ & $(1.98)$ & $(1.10)$ \\
\hline \multirow[t]{2}{*}{ FOMC Statement $_{\mathrm{t}}$} & $-0.300 * *$ & $0.311 *$ & 0.117 & $0.683^{*}$ \\
\hline & $(0.13)$ & $(0.17)$ & $(0.39)$ & $(0.37)$ \\
\hline \multirow[t]{2}{*}{$\Delta \mathrm{CPI}_{\mathrm{t}}$} & -0.229 & 0.024 & -0.095 & 0.371 \\
\hline & $(0.15)$ & $(0.20)$ & $(0.51)$ & $(0.48)$ \\
\hline \multirow[t]{2}{*}{ FOMC Mins.t } & 0.074 & -0.197 & -0.617 & -0.194 \\
\hline & $(0.14)$ & $(0.18)$ & $(0.42)$ & $(0.39)$ \\
\hline \multirow[t]{2}{*}{$\mathrm{GDP}_{\mathrm{t}}$} & -0.010 & -0.119 & 0.438 & -0.419 \\
\hline & $(0.16)$ & $(0.21)$ & $(0.52)$ & $(0.49)$ \\
\hline \multirow[t]{2}{*}{ Jobless Claims ${ }_{t}$} & $-0.121 *$ & 0.098 & $0.409 * *$ & 0.039 \\
\hline & $(0.07)$ & $(0.09)$ & $(0.20)$ & $(0.19)$ \\
\hline \multirow[t]{2}{*}{$\Delta \mathrm{PPI}_{\mathrm{t}}$} & -0.190 & -0.005 & 0.516 & -0.269 \\
\hline & $(0.14)$ & $(0.18)$ & $(0.38)$ & $(0.36)$ \\
\hline \multirow[t]{2}{*}{ ISM Manuf.t } & 0.126 & -0.159 & -0.405 & -0.134 \\
\hline & $(0.13)$ & $(0.18)$ & $(0.43)$ & $(0.40)$ \\
\hline \multirow{2}{*}{ Spread $_{i, t}$} & $-2.349 * * *$ & $0.674 * *$ & $3.349 * * *$ & $-3.524 * * *$ \\
\hline & $(0.28)$ & $(0.27)$ & $(0.84)$ & $(0.63)$ \\
\hline \multirow[t]{2}{*}{ Volume $_{i, t}$} & $-0.701 * * *$ & -0.588 & -1.897 & -0.447 \\
\hline & $(0.10)$ & $(0.36)$ & $(1.27)$ & $(0.49)$ \\
\hline \multirow[t]{2}{*}{ Volatility $_{i, t}$} & $0.079 * * *$ & 0.093 & 1.667 & $-2.078 * *$ \\
\hline & $(0.02)$ & $(0.07)$ & $(1.26)$ & $(0.83)$ \\
\hline R-sq. & 0.212 & 0.040 & 0.121 & 0.189 \\
\hline Obs. & 647 & 647 & 647 & 647 \\
\hline
\end{tabular}




\section{Table 9}

U.S. Macroeconomic News and Information Shares Across Quantitative Easing Periods. The Panels A, B, C, and D report the regression analysis across Treasury futures contracts for four maturities: two, five, ten, 30 years. NewsDayt is a dummy variable equal to 1 if on day $t$ there

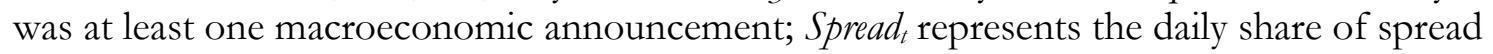
computed as the daily average of price reversals of each maturity contract divided by the sum over

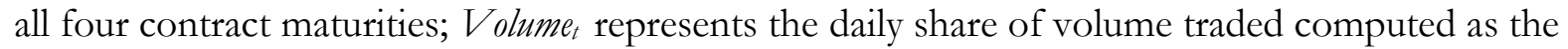
contract specific daily number of trades divided by the sum of all trades for the four contract

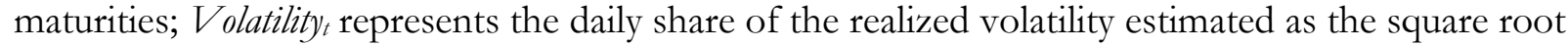
of the sum of squared five-minute returns of each contract maturity divided by the sum of realized volatilities of the four contract maturities. Refer to Table 3 for details concerning the macroeconomic announcements.

\begin{tabular}{|c|c|c|c|c|c|}
\hline \multicolumn{6}{|c|}{ Panel A } \\
\hline & \multicolumn{5}{|c|}{ Treasury Futures Information Shares -2 yrs } \\
\hline & QE1 & Pre-QE2 & QE2 & Per-QE3 & QE3 \\
\hline \multirow[t]{2}{*}{ Constant } & $-2.038^{* * *}$ & 29.070 & -25.177 & 31.182 & $25.225^{*}$ \\
\hline & $(1.11)$ & $(25.01)$ & $(28.72)$ & $(30.77)$ & $(13.76)$ \\
\hline \multirow[t]{2}{*}{ FOMC Statement $_{\mathrm{t}}$} & -0.409 & -1.039 & -0.030 & 0.325 & $-0.500^{* *}$ \\
\hline & $(0.27)$ & $(0.68)$ & $(0.41)$ & $(0.34)$ & $(0.22)$ \\
\hline \multirow[t]{2}{*}{$\Delta \mathrm{CPI}_{\mathrm{t}}$} & 0.082 & -0.053 & -0.544 & -0.340 & -0.087 \\
\hline & $(0.33)$ & $(0.53)$ & $(0.45)$ & $(0.30)$ & $(0.24)$ \\
\hline \multirow[t]{2}{*}{ FOMC Mins.t } & -0.125 & -0.383 & -0.216 & $0.485^{*}$ & 0.127 \\
\hline & $(0.43)$ & $(0.42)$ & $(0.56)$ & $(0.28)$ & $(0.20)$ \\
\hline \multirow[t]{2}{*}{$\mathrm{GDP}_{\mathrm{t}}$} & 0.152 & -0.548 & -0.436 & 0.151 & 0.074 \\
\hline & $(0.31)$ & $(0.54)$ & $(0.75)$ & $(0.36)$ & $(0.23)$ \\
\hline \multirow[t]{2}{*}{ Jobless Claims $_{t}$} & -0.101 & 0.077 & -0.346 & 0.161 & -0.108 \\
\hline & $(0.13)$ & $(0.20)$ & $(0.24)$ & $(0.17)$ & $(0.11)$ \\
\hline \multirow[t]{2}{*}{$\Delta \mathrm{PPI}_{\mathrm{t}}$} & -0.036 & 0.040 & -0.699 & -0.220 & -0.101 \\
\hline & $(0.24)$ & $(0.40)$ & $(0.36)$ & $(0.30)$ & $(0.28)$ \\
\hline \multirow[t]{2}{*}{ ISM Manuf.t } & -0.242 & -0.640 & -0.063 & 0.681 & $0.494 * *$ \\
\hline & $(0.22)$ & $(0.47)$ & $(0.55)$ & $(0.34)$ & $(0.22)$ \\
\hline \multirow[t]{2}{*}{ Spread $_{i, t}$} & $-1.431 * * *$ & 13.426 & -12.869 & 14.033 & $11.878^{*}$ \\
\hline & $(0.39)$ & (12.04) & $(13.84)$ & (14.83) & $(6.61)$ \\
\hline \multirow[t]{2}{*}{ Volume $_{\mathrm{i}, \mathrm{t}}$} & -0.295 & -0.509 & -0.287 & -0.149 & $-0.683 * * *$ \\
\hline & $(0.29)$ & $(0.39)$ & $(0.54)$ & $(0.27)$ & $(0.16)$ \\
\hline \multirow{2}{*}{ Volatility $_{i, t}$} & -0.015 & $0.295^{* * *}$ & 0.071 & 0.051 & $0.105^{* * *}$ \\
\hline & $(0.04)$ & $(0.07)$ & $(0.08)$ & $(0.05)$ & $(0.04)$ \\
\hline R-sq. & 0.103 & 0.426 & 0.161 & 0.115 & 0.199 \\
\hline Obs. & 114 & 67 & 69 & 100 & 155 \\
\hline
\end{tabular}


Table 9, continued

\begin{tabular}{|c|c|c|c|c|c|}
\hline \multicolumn{6}{|c|}{ Panel B } \\
\hline & \multicolumn{5}{|c|}{ Treasury Futures Information Shares -5 yrs } \\
\hline & QE1 & Pre-QE2 & QE2 & Per-QE3 & QE3 \\
\hline \multirow[t]{2}{*}{ Constant } & 1.893 & -17.343 & 38.287 & -40.490 & -11.791 \\
\hline & $(1.24)$ & $(26.02)$ & $(30.21)$ & $(33.20)$ & $(16.04)$ \\
\hline \multirow[t]{2}{*}{ FOMC Statement $_{t}$} & $0.496^{*}$ & $1.237^{*}$ & 0.220 & -0.317 & 0.266 \\
\hline & $(0.30)$ & $(0.70)$ & $(0.43)$ & $(0.37)$ & $(0.26)$ \\
\hline \multirow[t]{2}{*}{$\Delta \mathrm{CPI}_{\mathrm{t}}$} & -0.231 & 0.073 & 0.296 & 0.467 & 0.065 \\
\hline & $(0.37)$ & $(0.55)$ & $(0.47)$ & $(0.32)$ & $(0.28)$ \\
\hline \multirow{2}{*}{ FOMC Mins.t } & 0.540 & 0.126 & 0.222 & -0.477 & -0.095 \\
\hline & $(0.48)$ & $(0.44)$ & $(0.58)$ & $(0.31)$ & $(0.23)$ \\
\hline \multirow[t]{2}{*}{$\mathrm{GDP}_{\mathrm{t}}$} & -0.239 & 0.285 & 0.514 & -0.132 & 0.022 \\
\hline & $(0.35)$ & $(0.56)$ & $(0.79)$ & $(0.39)$ & $(0.27)$ \\
\hline \multirow[t]{2}{*}{ Jobless Claimst } & 0.112 & -0.040 & 0.360 & -0.135 & 0.138 \\
\hline & $(0.14)$ & $(0.20)$ & $(0.25)$ & $(0.19)$ & $(0.13)$ \\
\hline \multirow[t]{2}{*}{$\Delta \mathrm{PPI}_{\mathrm{t}}$} & 0.161 & -0.065 & 0.430 & 0.331 & 0.222 \\
\hline & $(0.26)$ & $(0.41)$ & $(0.38)$ & $(0.33)$ & $(0.33)$ \\
\hline \multirow[t]{2}{*}{ ISM Manuf.t } & 0.371 & 0.705 & 0.226 & $-0.700^{*}$ & $-0.575^{* *}$ \\
\hline & $(0.24)$ & $(0.49)$ & $(0.58)$ & $(0.36)$ & $(0.26)$ \\
\hline \multirow[t]{2}{*}{ Spread $_{i, t}$} & $1.302^{* *}$ & -7.558 & 19.463 & -18.374 & -5.275 \\
\hline & $(0.43)$ & $(12.52)$ & (14.56) & $(16.00)$ & $(7.71)$ \\
\hline \multirow[t]{2}{*}{ Volume $_{\mathrm{i}, \mathrm{t}}$} & $0.558 *$ & 0.385 & 0.118 & 0.134 & $0.661 * * *$ \\
\hline & $(0.33)$ & $(0.41)$ & $(0.56)$ & $(0.29)$ & $(0.18)$ \\
\hline \multirow{2}{*}{ Volatility i,t } & 0.052 & $-0.269 * * *$ & -0.076 & -0.037 & $-0.124^{* * *}$ \\
\hline & $(0.05)$ & $(0.08)$ & $(0.08)$ & $(0.05)$ & $(0.04)$ \\
\hline R-Sq. & 0.104 & 0.356 & 0.128 & 0.113 & 0.139 \\
\hline Obs. & 114 & 67 & 69 & 100 & 155 \\
\hline
\end{tabular}


Table 9, continued

\begin{tabular}{|c|c|c|c|c|c|}
\hline \multicolumn{6}{|c|}{ Panel C } \\
\hline & \multicolumn{5}{|c|}{ Treasury Futures Information Shares - 10 yrs } \\
\hline & QE1 & Pre-QE2 & QE2 & Per-QE3 & QE3 \\
\hline \multirow[t]{2}{*}{ Constant } & -0.523 & -55.645 & -12.080 & $-126.220^{*}$ & $-108.866^{* * *}$ \\
\hline & $(2.11)$ & $(42.11)$ & $(43.43)$ & $(64.39)$ & $(21.17)$ \\
\hline \multirow[t]{2}{*}{ FOMC Statement $_{t}$} & 0.197 & 0.548 & -0.669 & $-1.420 *$ & $1.514 * * *$ \\
\hline & $(.51)$ & $(1.14)$ & $(0.61)$ & $(0.72)$ & $(0.44)$ \\
\hline \multirow[t]{2}{*}{$\Delta \mathrm{CPI}_{\mathrm{t}}$} & 0.390 & 0.287 & $1.358^{*}$ & -0.213 & -0.084 \\
\hline & $(0.63)$ & $(0.89)$ & $(0.67)$ & $(0.62)$ & $(0.47)$ \\
\hline \multirow[t]{2}{*}{ FOMC Mins.t } & -0.777 & $1.241 *$ & 0.848 & -0.358 & 0.253 \\
\hline & $(0.82)$ & $(0.71)$ & $(0.84)$ & $(0.59)$ & $(0.39)$ \\
\hline \multirow[t]{2}{*}{$\mathrm{GDP}_{\mathrm{t}}$} & -0.095 & $1.924 * *$ & -1.222 & 0.519 & -0.204 \\
\hline & $(0.59)$ & $(0.91)$ & $(1.13)$ & $(0.75)$ & $(0.46)$ \\
\hline \multirow[t]{2}{*}{ Jobless Claimst } & 0.140 & -0.244 & 0.577 & -0.248 & $0.614^{* * *}$ \\
\hline & $(0.24)$ & $(0.33)$ & $(0.36)$ & $(0.36)$ & $(0.21)$ \\
\hline \multirow[t]{2}{*}{$\Delta \mathrm{PPI}_{\mathrm{t}}$} & -0.364 & 0.595 & $1.651^{* * *}$ & 0.623 & $-0.956 *$ \\
\hline & $(0.45)$ & $(0.67)$ & $(0.55)$ & $(0.63)$ & $(0.56)$ \\
\hline \multirow[t]{2}{*}{ ISM Manuf.t } & -0.227 & 0.734 & -0.890 & -0.411 & -0.200 \\
\hline & $(0.41)$ & $(0.80)$ & $(0.83)$ & $(0.70)$ & $(0.44)$ \\
\hline \multirow[t]{2}{*}{ Spread $_{i, t}$} & 2.248 & -24.929 & -4.586 & $-58.533 *$ & $-50.861 * * *$ \\
\hline & $(0.74)$ & $(20.27)$ & $(20.92)$ & $(31.03)$ & $(13.06)$ \\
\hline \multirow[t]{2}{*}{ Volume $_{i, t}$} & -0.548 & 0.676 & 0.819 & 0.659 & $1.127^{* * *}$ \\
\hline & $(0.55)$ & $(0.66)$ & $(0.81)$ & $(0.57)$ & $(0.31)$ \\
\hline \multirow{2}{*}{ Volatility i,t } & -0.071 & $-0.514 * * *$ & 0.135 & -0.150 & -0.113 \\
\hline & $(0.08)$ & $(0.12)$ & $(0.12)$ & $(0.10)$ & $(0.07)$ \\
\hline R-sq. & 0.106 & 0.450 & 0.306 & 0.080 & 0.260 \\
\hline Obs. & 114 & 67 & 69 & 100 & 155 \\
\hline
\end{tabular}


Table 9, continued

\begin{tabular}{|c|c|c|c|c|c|}
\hline \multicolumn{6}{|c|}{ Panel D } \\
\hline & \multicolumn{5}{|c|}{ Treasury Futures Information Shares -30 yrs } \\
\hline & QE1 & Pre-QE2 & QE2 & Per-QE3 & QE3 \\
\hline \multirow[t]{2}{*}{ Constant } & 1.693 & -72.661 & -95.879 & 33.253 & $-51.777 *$ \\
\hline & $(2.26)$ & $(50.06)$ & $(57.90)$ & $(67.04)$ & $(30.56)$ \\
\hline \multirow[t]{2}{*}{ FOMC Statement $t_{t}$} & 0.458 & 0.177 & -0.459 & 0.429 & $1.282^{* * *}$ \\
\hline & $(0.54)$ & $(1.36)$ & $(0.82)$ & $(0.75)$ & $(0.49)$ \\
\hline \multirow[t]{2}{*}{$\Delta \mathrm{CPI}_{\mathrm{t}}$} & 0.101 & -0.043 & 1.219 & -0.596 & -0.052 \\
\hline & $(0.67)$ & $(1.05)$ & $(0.90)$ & $(0.65)$ & $(0.53)$ \\
\hline \multirow[t]{2}{*}{ FOMC Mins.t } & -0.930 & $1.584^{*}$ & -0.587 & -0.507 & 0.499 \\
\hline & $(0.88)$ & $(0.85)$ & $(1.12)$ & $(0.62)$ & $(0.44)$ \\
\hline \multirow[t]{2}{*}{$\mathrm{GDP}_{\mathrm{t}}$} & 0.275 & $2.125^{*}$ & 1.633 & -0.880 & -0.642 \\
\hline & $(0.64)$ & (1.08) & $(1.50)$ & $(0.78)$ & $(0.52)$ \\
\hline \multirow[t]{2}{*}{ Jobless Claims } & 0.398 & -0.123 & 0.370 & -0.087 & -0.109 \\
\hline & $(0.26)$ & $(039)$ & $(0.47)$ & $(0.38)$ & $(0.24)$ \\
\hline \multirow[t]{2}{*}{$\Delta \mathrm{PPI}_{\mathrm{t}}$} & -0.046 & 0.538 & 1.174 & -0.348 & $-1.326^{* *}$ \\
\hline & $(0.48)$ & $(0.79)$ & $(0.73)$ & $(0.66)$ & $(0.63)$ \\
\hline \multirow[t]{2}{*}{ ISM Manuf.t } & 0.212 & -0.813 & 0.054 & -0.198 & -0.322 \\
\hline & $(0.44)$ & $(0.95)$ & $(1.11)$ & $(0.73)$ & $(0.49)$ \\
\hline \multirow[t]{2}{*}{ Spread $_{i, t}$} & $3.981 * * *$ & -33.159 & -43.972 & 17.970 & -23.275 \\
\hline & $(0.79)$ & $(24.10)$ & $(27.90)$ & (32.31) & $(14.69)$ \\
\hline \multirow[t]{2}{*}{ Volume $_{\mathrm{i}, \mathrm{t}}$} & -0.836 & 0.731 & 0.664 & 0.436 & $0.756^{* *}$ \\
\hline & $(0.59)$ & $(0.78)$ & $(1.08)$ & $(0.59)$ & $(0.35)$ \\
\hline \multirow{2}{*}{ Volatility $_{i, t}$} & 0.037 & -0.061 & -0.072 & -0.064 & -0.061 \\
\hline & $(0.09)$ & $(0.15)$ & $(0.16)$ & $(0.11)$ & $(0.08)$ \\
\hline R-sq. & 0.206 & 0.171 & 0.166 & 0.072 & 0.123 \\
\hline Obs. & 114 & 67 & 69 & 100 & 155 \\
\hline
\end{tabular}




\section{Table 10}

Specific U.S. Macroeconomic Announcements and Information Shares

The table report the regression analysis for log-transformed maturity-specific information

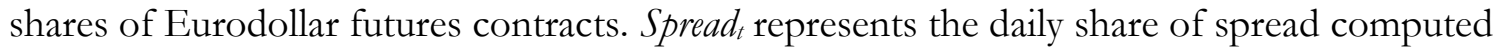
as the daily average of price reversals of each maturity contract divided by the sum over all four contract maturities; Volume $e_{t}$ represents the daily share of volume traded computed as the contract specific daily number of trades divided by the sum of all trades for the four contract maturities; Volatility represents the daily share of the realized volatility estimated as the square root of the sum of squared five-minute returns of each contract maturity divided by the sum of realized volatilities of the four contract maturities.

\begin{tabular}{|c|c|c|c|c|}
\hline & \multicolumn{4}{|c|}{ Eurodollar Futures Information Shares } \\
\hline & $1 \mathrm{grtr}$ & 3 qrtr & 5 qrtr & 9 qrtr \\
\hline \multirow[t]{2}{*}{ Constant } & $-0.576^{* *}$ & $-4.999 * * *$ & $-1.463^{* *}$ & $1.827 * * *$ \\
\hline & $(0.67)$ & $(0.49)$ & $(0.68)$ & $(0.62)$ \\
\hline \multirow[t]{2}{*}{ FOMC Statement $_{t}$} & $-0.447 * *$ & -0.192 & $0.584 * *$ & 0.250 \\
\hline & $(0.22)$ & $(0.35)$ & $(0.27)$ & $(0.36)$ \\
\hline \multirow[t]{2}{*}{$\Delta \mathrm{CPI}_{\mathrm{t}}$} & $-0.344^{* *}$ & 0.320 & $0.320^{*}$ & -0.280 \\
\hline & $(0.16)$ & $(0.25)$ & $(0.19)$ & $(0.26)$ \\
\hline \multirow[t]{2}{*}{ FOMC Mins.t } & 0.209 & -0.279 & -0.322 & -0.194 \\
\hline & $(0.23)$ & $(0.36)$ & $(0.27)$ & $(0.38)$ \\
\hline \multirow[t]{2}{*}{$\mathrm{GDP}_{\mathrm{t}}$} & $-0.282^{*}$ & 0.229 & 0.193 & -0.377 \\
\hline & $(0.16)$ & $(0.25)$ & $(0.19)$ & $(0.27)$ \\
\hline \multirow[t]{2}{*}{ Nonfarm Payroll $_{\mathrm{t}}$} & $-0.372 * * *$ & $0.334 *$ & 0.224 & $0.578^{* * *}$ \\
\hline & $(0.13)$ & $(0.20)$ & $(0.15)$ & $(0.22)$ \\
\hline \multirow[t]{2}{*}{ Jobless Claims $_{t}$} & 0.059 & -0.053 & -0.098 & 0.217 \\
\hline & $(0.08)$ & $(0.13)$ & $(0.10)$ & $(0.14)$ \\
\hline \multirow[t]{2}{*}{$\Delta \mathrm{PPI}_{\mathrm{t}}$} & -0.064 & -0.151 & 0.123 & 0.122 \\
\hline & $(0.18)$ & $(0.28)$ & $(0.21)$ & $(0.27)$ \\
\hline \multirow[t]{2}{*}{ ISM Manuf.t } & -0.008 & 0.054 & -0.002 & 0.041 \\
\hline & $(0.16)$ & $(0.24)$ & $(0.19)$ & $(0.26)$ \\
\hline \multirow[t]{2}{*}{ Spread $_{i, t}$} & $-0.402^{* *}$ & $-0.827 * *$ & $1.029 * * *$ & $0.456^{* *}$ \\
\hline & $(0.18)$ & $(0.37)$ & $(0.30)$ & $(0.21)$ \\
\hline \multirow[t]{2}{*}{ Volume $_{\mathrm{i}, \mathrm{t}}$} & $-1.036 * * *$ & 0.076 & $0.784 * * *$ & -0.007 \\
\hline & $(0.10)$ & $(0.11)$ & $(0.15)$ & $(0.08)$ \\
\hline \multirow{2}{*}{ Volatility $_{\mathrm{i}, \mathrm{t}}$} & $-0.269 * * *$ & $0.745^{* * *}$ & $1.389 * * *$ & $-2.690 * * *$ \\
\hline & $(0.08)$ & $(0.24)$ & $(0.22)$ & $(0.25)$ \\
\hline R-sq. & 0.160 & 0.051 & 0.147 & 0.264 \\
\hline Obs. & 817 & 817 & 817 & 817 \\
\hline
\end{tabular}




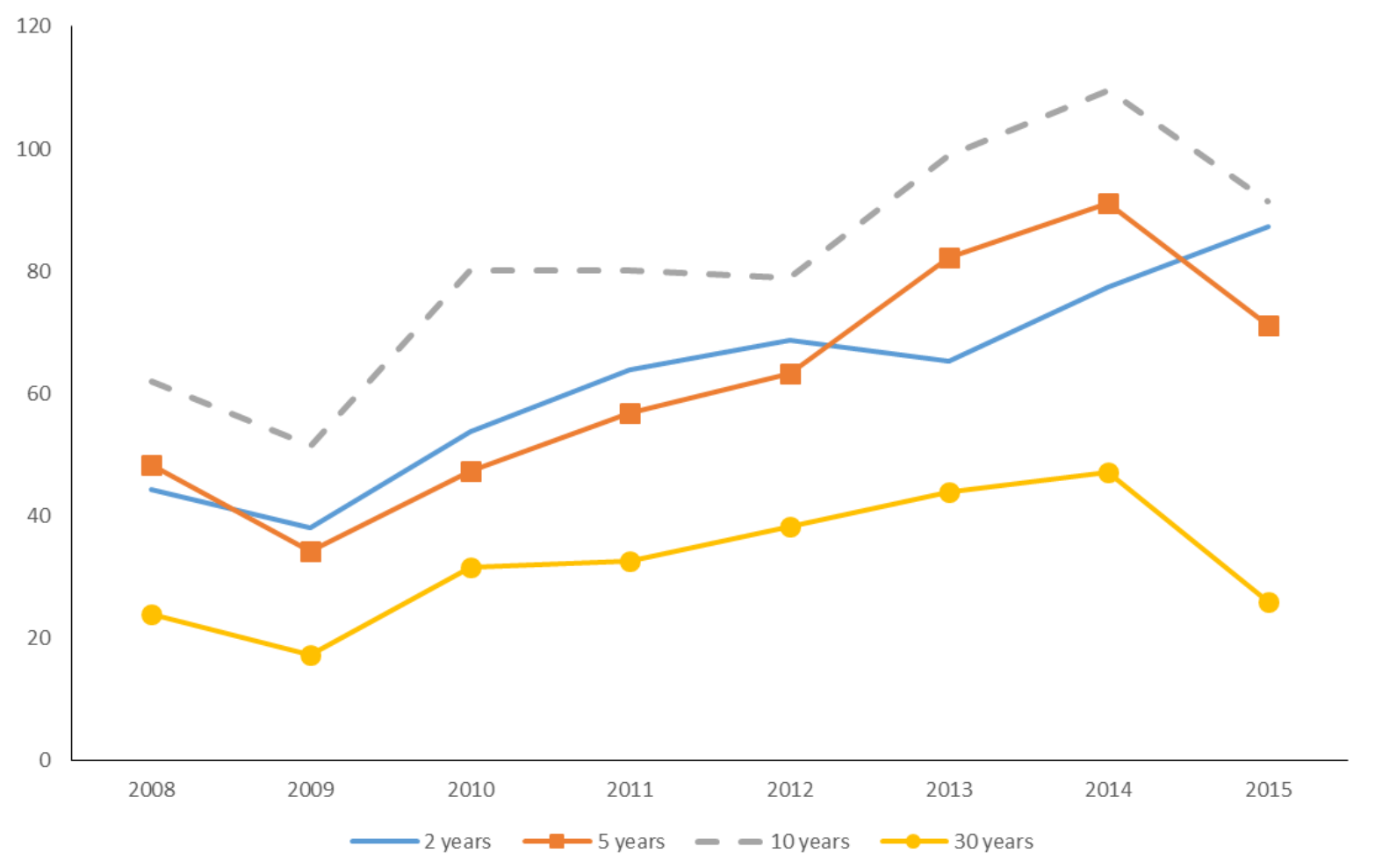

Figure 1. Average trading volume for Treasury Futures

This figure shows the average yearly trading volume as the number of Treasury futures contracts per second with maturities of $2,5,10$, and thirty years. 


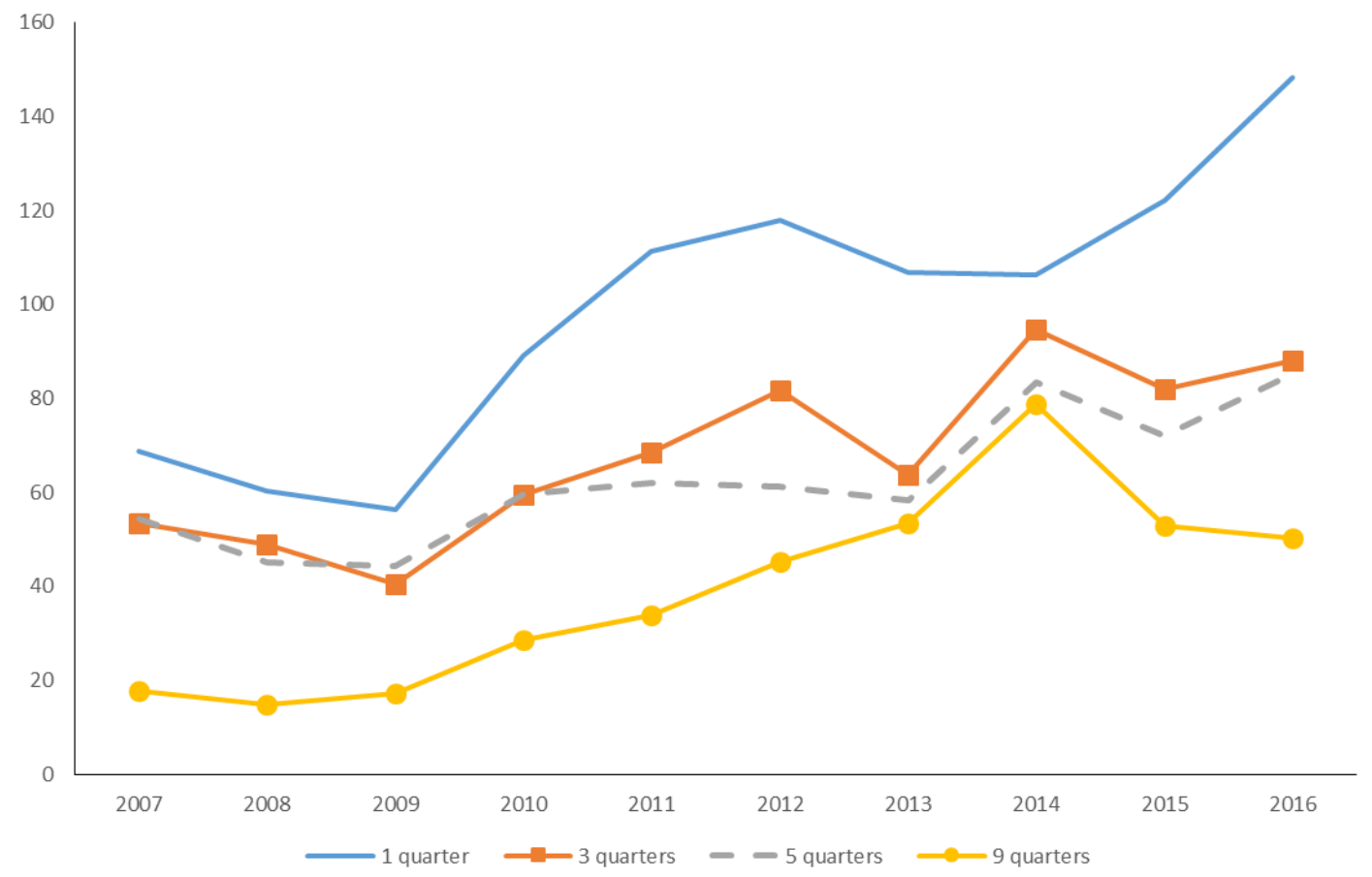

Figure 2. Average trading volume for Eurodollar Futures

This figure shows the average yearly trading volume as the number of Eurodollar futures contracts per second with maturities of 1, 3, 5 and 9 quarters. 
Shock to 2-year contract

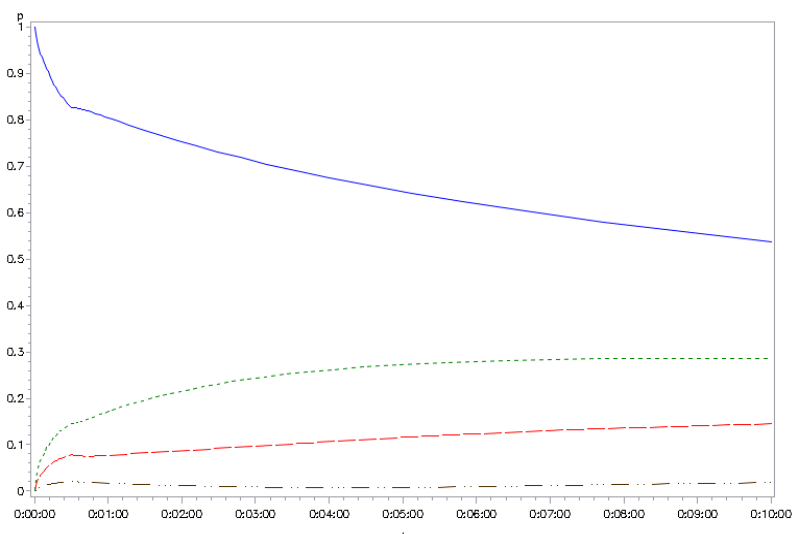

Shock to 10-year contract

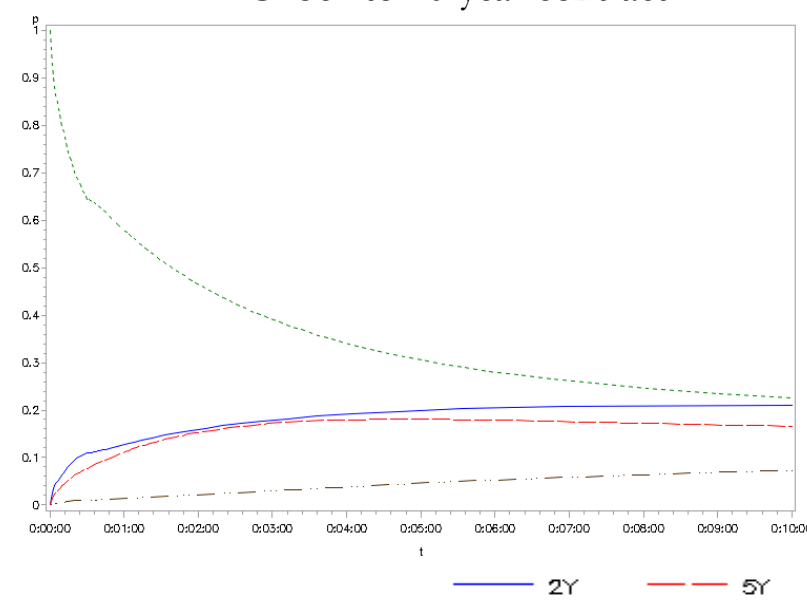

Shock to 5 -year contract

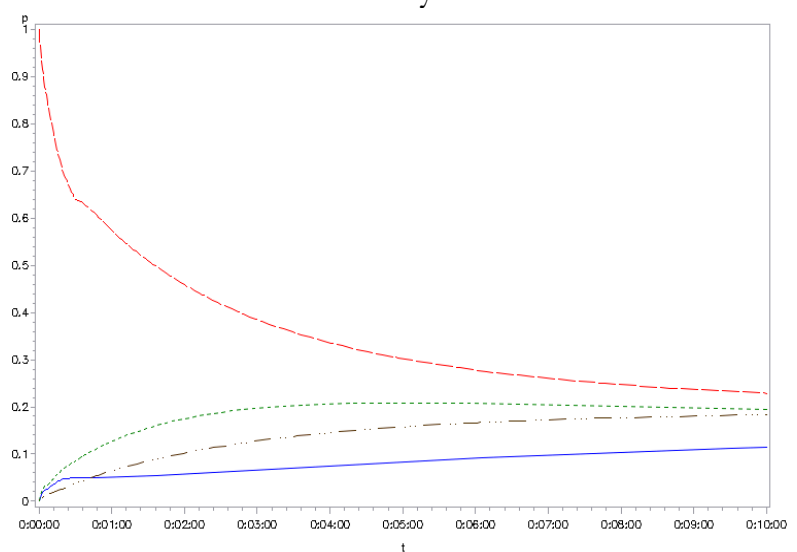

Shock to 30-year contract

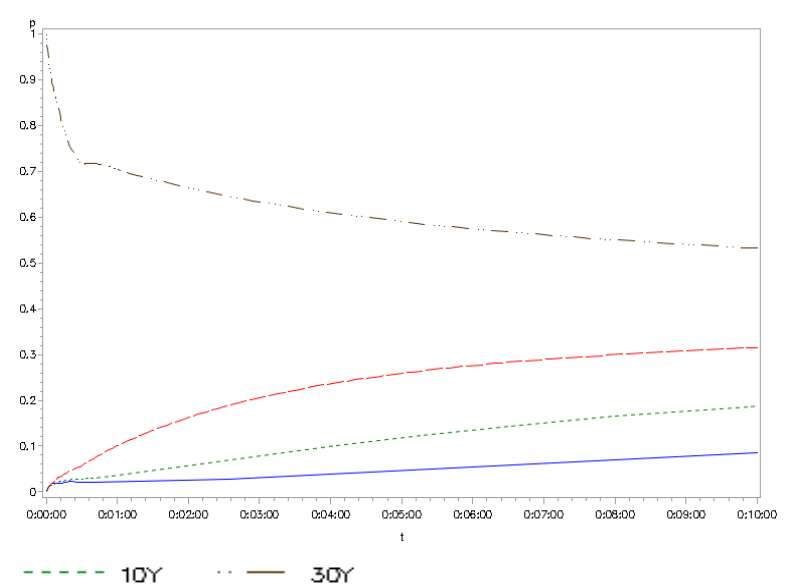

Figure 3a. Cumulative impulse response functions.

This figure shows the impulse response function for Treasury futures contracts during a ten minute window. 


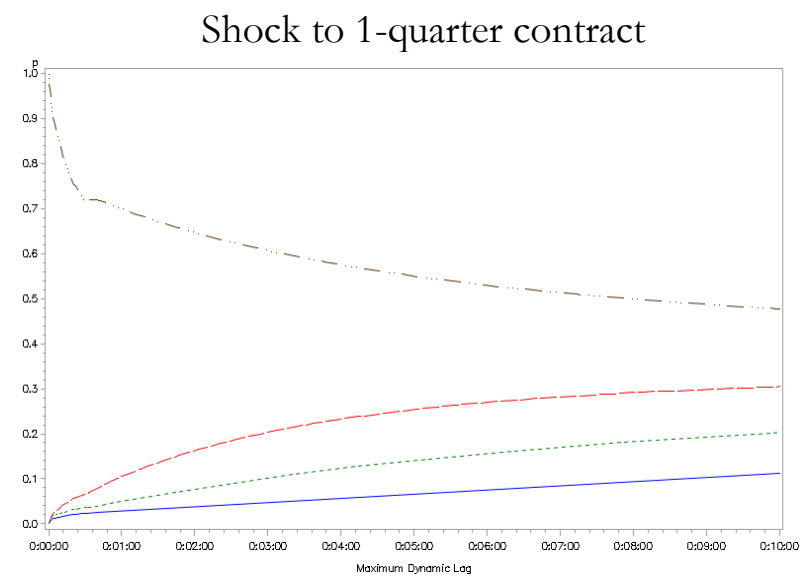

Shock to 5-quarter contract
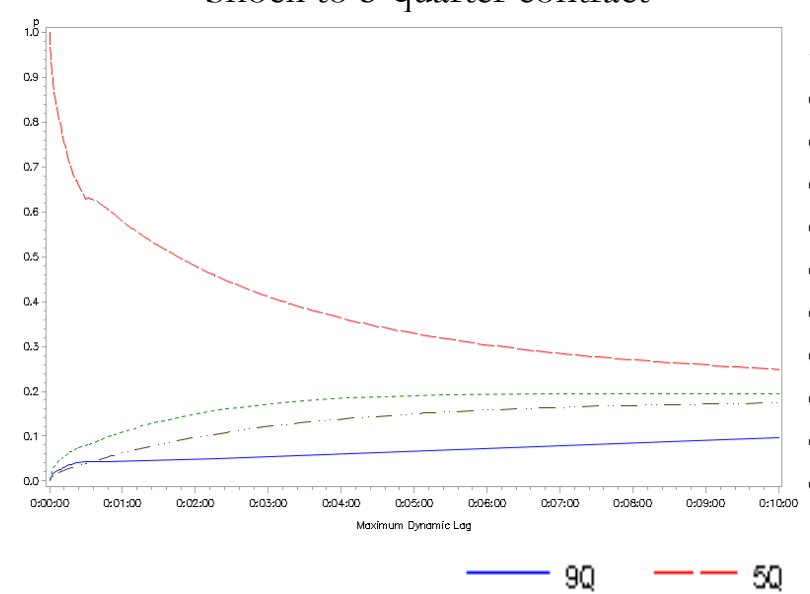

Shock to 3-quarter contract

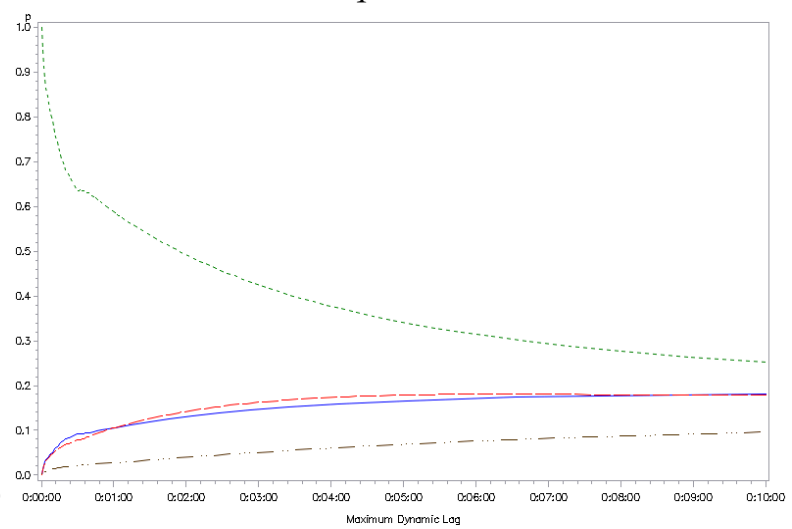

Shock to 9-quarter contract

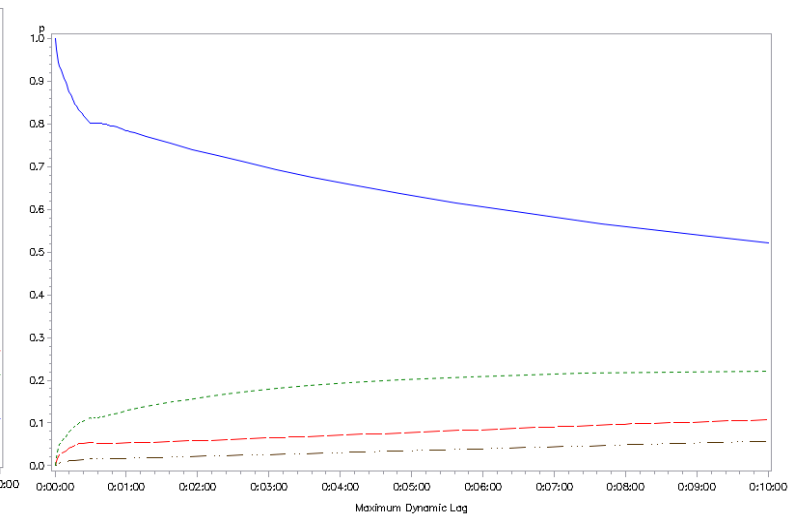

$-\cdots-30 \quad \cdots-10$

Figure 3b. Cumulative impulse response functions.

This figure shows the impulse response function for Eurodollar futures contracts during a ten minute window. 


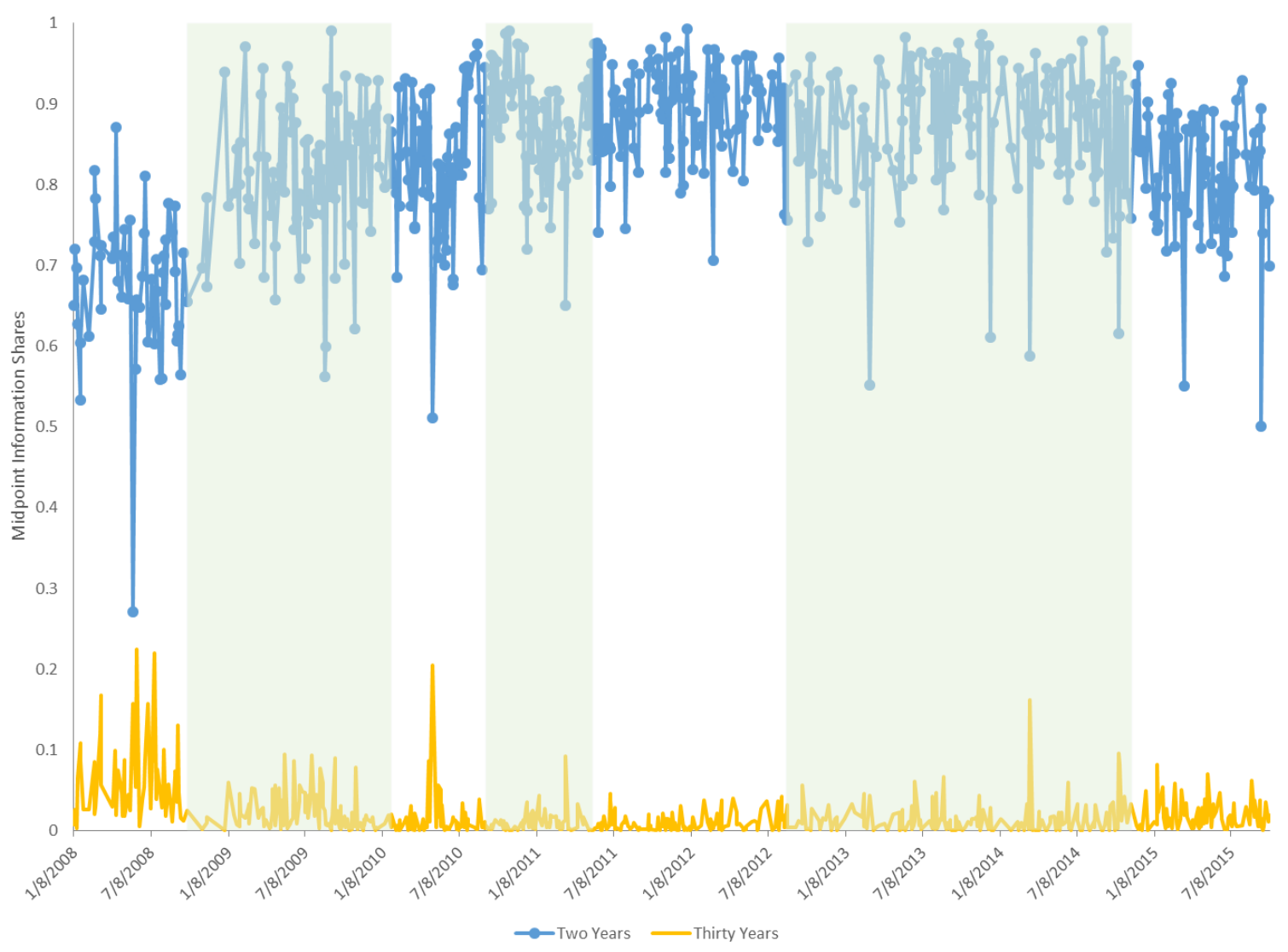

Figure 4. Treasury futures contracts midpoint daily information shares, two and thirty years. This figure shows the midpoint daily information shares of the shortest and longest maturities for the Treasury futures contracts ( 2 and 30 years). The shaded regions represent the three quantitative easing phases adopted by the Federal Reserve Bank: QE1 spans from November $25^{\text {th }}, 2008$ to March 31 ${ }^{\text {st }} 2010$; QE2 spans from November $3^{\text {rd }}, 2010$ to June 30 ${ }^{\text {th }}$, 2011; QE3 spans from September 13 $3^{\text {th }}, 2012$ to October 29 $9^{\text {th }}, 2014$. 


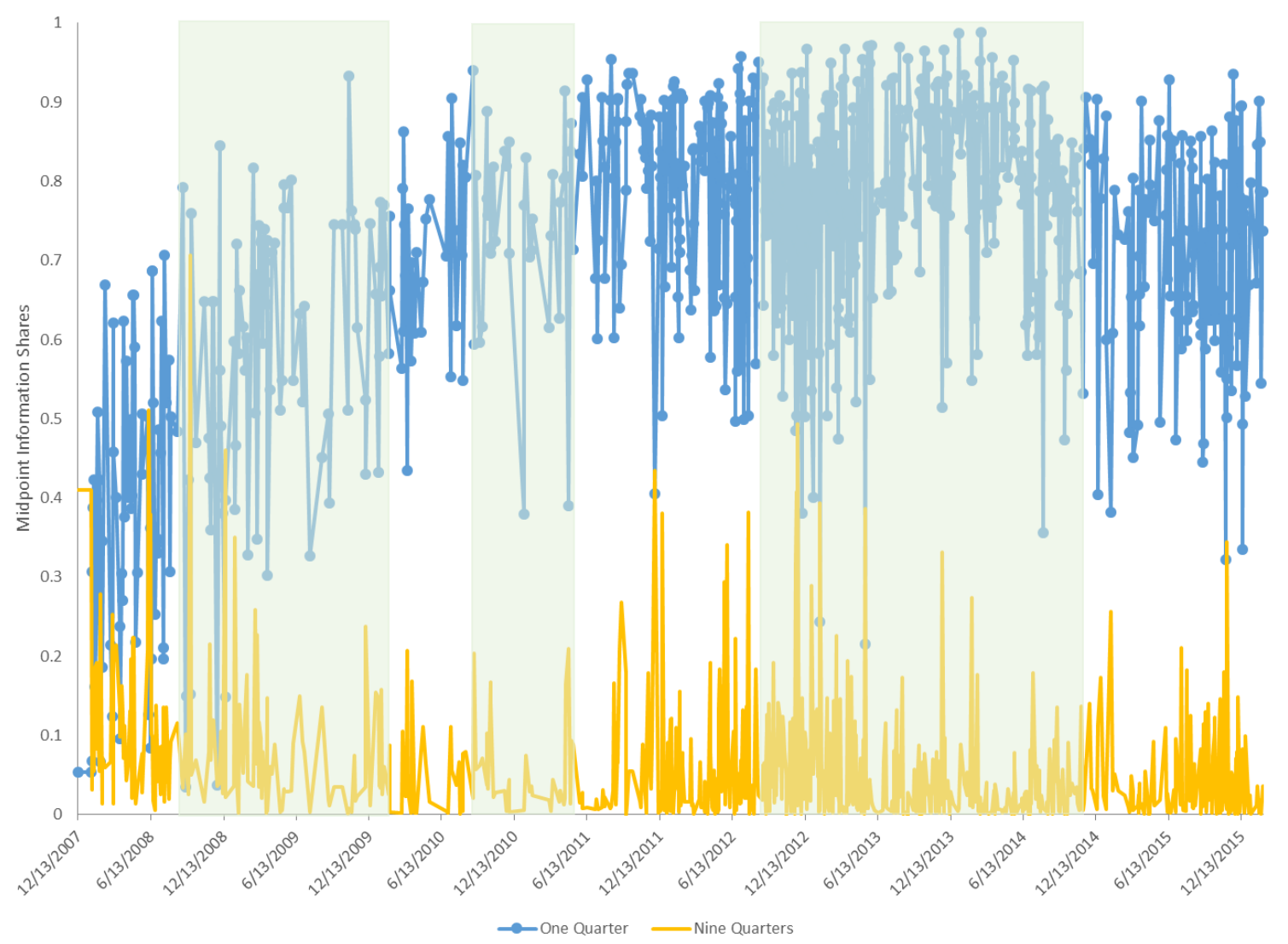

Figure 5. Eurodollar futures contracts midpoint daily information shares, one and nine quarters.

This figure shows the midpoint daily information shares of the shortest and longest maturities for the Eurodollar futures contracts (1 quarter and 9 quarters). The shaded regions represent the three quantitative easing phases adopted by the Federal Reserve Bank: QE1 spans from November 25 $5^{\text {th }}, 2008$ to March 31 ${ }^{\text {st }} 2010$; QE2 spans from November $3^{\text {rd }}, 2010$ to June $30^{\text {th }}$, 2011; QE3 spans from September 13 ${ }^{\text {th }}, 2012$ to October 29 ${ }^{\text {th }}, 2014$. 